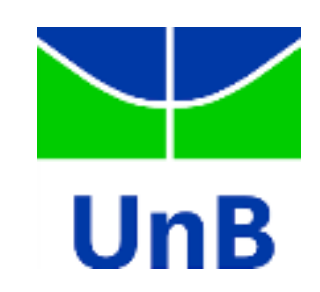

UNIVERSIDADE DE BRASÍLIA

CENTRO DE ESTUDOS AVANÇADOS MULTIDISCIPLINARES

LEONARDO DA ROSA FERNANDES

CONSTRUINDO A PRÓPRIA ESCADA: ANÁLISE E PROPOSIÇÕES RUMO À EFETIVIDADE DOS ESTÍMULOS AO SETOR INDUSTRIAL EM PAÍSES EM PROCESSO DE DESENVOLVIMENTO

Brasília, novembro de 2015. 
LEONARDO DA ROSA FERNANDES

CONSTRUINDO A PRÓPRIA ESCADA: ANÁLISE E PROPOSIÇÕES RUMO À EFETIVIDADE DOS ESTÍMULOS AO SETOR INDUSTRIAL EM PAÍSES EM PROCESSO DE DESENVOLVIMENTO

Dissertação de mestrado apresentada ao Programa de Pós-Graduação em Desenvolvimento, Sociedade e Cooperação Internacional - PPGDSCI do Centro de Estudos Avançados Multidisciplinares - CEAM como requisito parcial para obtenção do título de Mestre em Cooperação Internacional e Desenvolvimento.

Orientadora: Maria de Fátima Souza e Silva

Brasília, novembro de 2015. 


\section{CONSTRUINDO A PRÓPRIA ESCADA: ANÁLISE E PROPOSIÇÕES RUMO À EFETIVIDADE DOS ESTÍMULOS AO SETOR INDUSTRIAL EM PAÍSES EM PROCESSO DE DESENVOLVIMENTO}

Dissertação de mestrado apresentada ao Programa de Pós-Graduação em Desenvolvimento, Sociedade e Cooperação Internacional - PPGDSCI do Centro de Estudos Avançados Multidisciplinares - CEAM como requisito parcial para obtenção do título de Mestre em Cooperação Internacional e Desenvolvimento.

Orientadora: Maria de Fátima Souza e Silva

Aprovado pela banca examinadora em 16 de dezembro de 2015 .

Professora Doutora Maria de Fátima Souza e Silva

Orientadora

Centro de Estudos Avançados Multidisciplinares - UNB

\section{Professor Doutor Rodrigo Pires de Campos}

Membro Examinador Interno

Centro de Estudos Avançados Multidisciplinares - UNB

Professor Doutor Jorge Saba Arbache Filho

Membro Examinador Externo

Faculdade de Economia - UNB 


\title{
CONSTRUINDO A PRÓPRIA ESCADA: ANÁLISE E PROPOSIÇÕES RUMO À EFETIVIDADE DOS ESTÍMULOS AO SETOR INDUSTRIAL EM PAÍSES EM PROCESSO DE DESENVOLVIMENTO
}

\begin{abstract}
RESUMO
Modernizar o setor industrial de países em desenvolvimento resulta, a princípio, no aprimoramento de seus indicadores econômicos e sociais. Entretanto, as desigualdades crescentes entre países desenvolvidos e em desenvolvimento põem em dúvida se os indicadores de estímulo industrial e, principalmente, as propostas de organizações internacionais a esse respeito são realmente efetivas para o alcance desse objetivo. Nesta dissertação busca-se propor alternativas às políticas e aos projetos de desenvolvimento industrial elaborados para economias em processo de desenvolvimento, por meio da análise de políticas industriais utilizadas em países desenvolvidos e das diretrizes da Organização das Nações Unidas para o Desenvolvimento Industrial (ONUDI), principal organização internacional dedicada ao setor. Com base na premissa de que as atuais políticas públicas aplicadas aos setores industriais de países em desenvolvimento encontram limitações para obter efeitos na diminuição das desigualdades de renda, buscou-se caracterizar os elementos que contribuem à reformulação de políticas industriais direcionadas a países em desenvolvimento, por meio da proposição de modelo teórico embasado em ecossistemas socioeconômicos. Nesse contexto, foi evidenciado que, para melhorar a efetividade das políticas públicas voltadas ao desenvolvimento industrial, é necessário dedicar-se à construção, prévia à aplicação dessas políticas, de um ecossistema favorável ao aumento da densidade industrial, do crescimento econômico e do bem-estar social, de acordo com as distintas realidades institucionais dos países em desenvolvimento.
\end{abstract}

PALAVRAS-CHAVE: Desenvolvimento industrial. Políticas públicas. Políticas industriais. ONUDI. Convergência de renda. Redução da pobreza. Inclusão social. 


\title{
BUILDING YOUR OWN LADDER: ANALYSIS AND PROPOSALS TOWARDSTHE EFFECTIVENESS OF INDUSTRIAL SECTOR STIMULUS IN DEVELOPING COUNTRIES
}

\begin{abstract}
The modernization of industrial sectors in developing countries results in the improvement of their economic and social indicators. Growing inequalities between developed and developing countries, however, cast doubt on whether indicators of industrial stimulus and proposals of international organizations in this regard are actually effective for those means. This dissertation seeks to propose alternatives to industrial policies and projects of industrial development applied to developing economies through the analysis of industrial policies guidelines adopted by developed countries and those applied by the United Nations Industrial Development Organization (UNIDO), main international organization dedicated to develop industrial sectors. Based on the assumption that current policies applied to industrial sectors in developing countries has limited positive impacts on reducing income inequalities, the dissertation search to characterize elements that could contribute to the reformulation of industrial policies aimed at developing countries through a theoretical model proposition grounded in socioeconomic ecosystems. In this context, it was verified that to improve the effectiveness of public policies aimed at industrial development, it is necessary to build, prior to the implementation of these policies, a favorable ecosystem, in order to increase industrial density, economic growth and social welfare, according to the diverse institutional realities of developing countries.
\end{abstract}

KEYWORDS: Industrial development. Public policy. Industrial policies. UNIDO. Income convergence. Poverty reduction. Social inclusion. 


\section{SUMÁRIO}

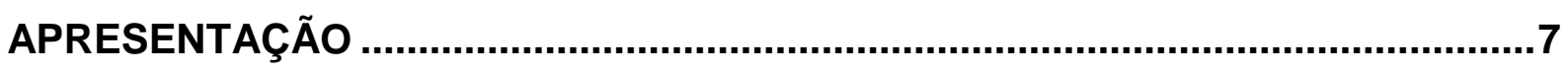

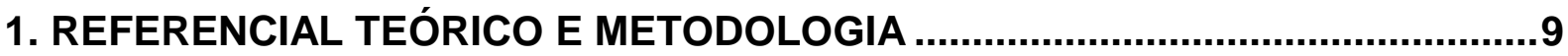

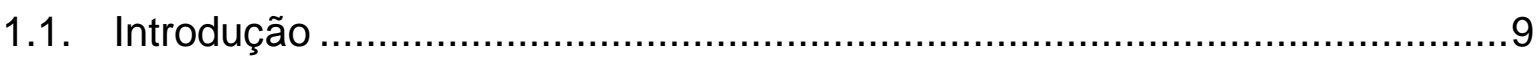

1.2. A definição do objeto de estudo e o problema ............................................11

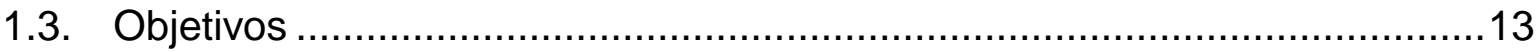

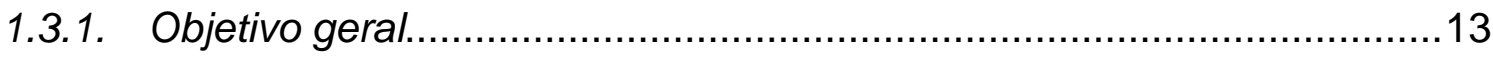

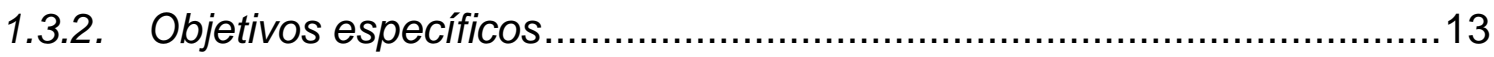

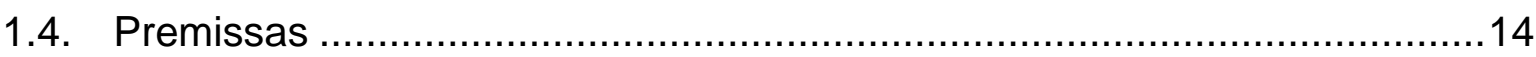

1.5. As escolhas teóricas e metodológicas ..................................................... 15

1.5.1. Revisão de literatura - do Chute a Escada à Sociedade do

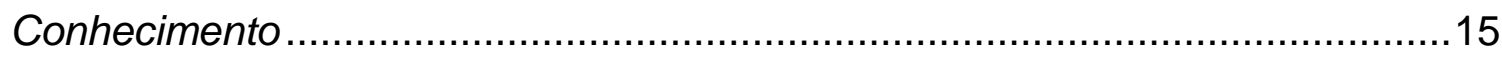

1.5.2. Tendências econômicas globais que afetam o setor industrial...............20

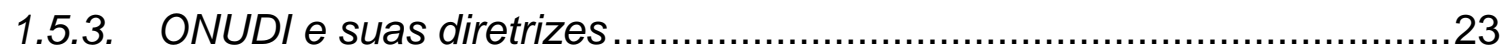

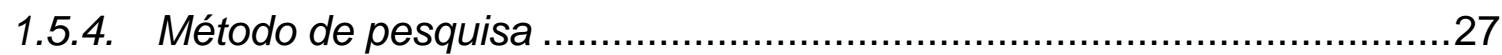

\section{O SETOR INDUSTRIAL COMO ESTRATÉGIA PARA O DESENVOLVIMENTO 29}

2.1. Reindustrialização dos industrializados e a importância das manufaturas...29

2.2. As tendências econômicas globais e o setor industrial ...............................32

2.3. Megatendências que impactam na questão da divergência..........................36

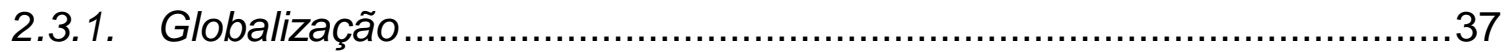

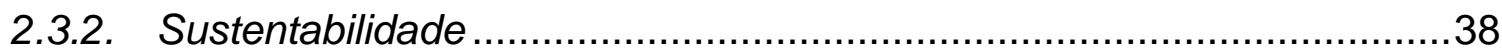

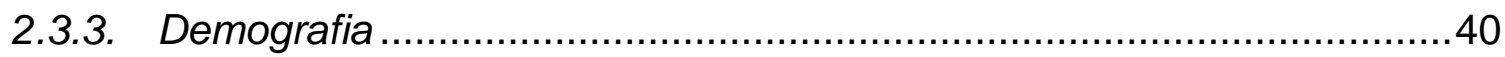

2.3.4. Cadeias Globais de Valor ........................................................... 40

2.3.5. Serviços, conhecimento e geração de riquezas ...................................43

2.3.6. Fluxos internacionais de comércio...................................................46

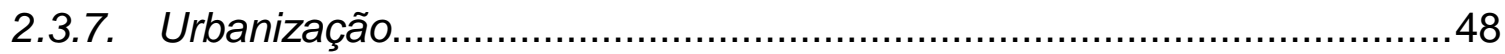

2.3.8. Ameaças a estabilidade global .......................................................... 49

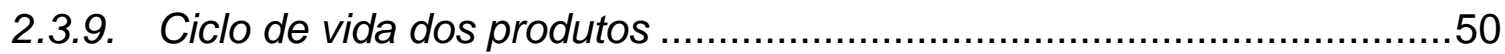

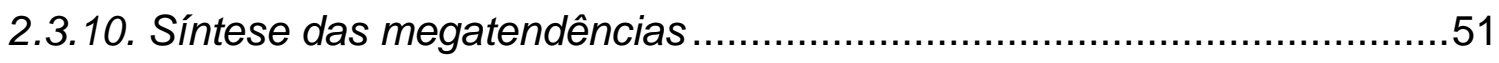

3. COMPARATIVO ENTRE AS POLÍTICAS INDUSTRIAIS .................................53

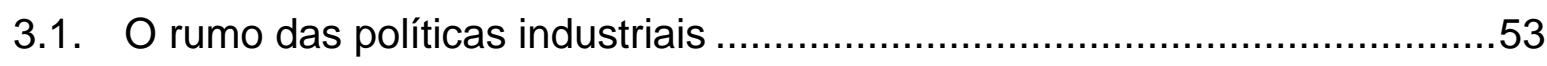

3.1.1. Políticas industriais do Reino Unido .................................................55 
3.1.2. Políticas industriais dos Estados Unidos ...........................................57

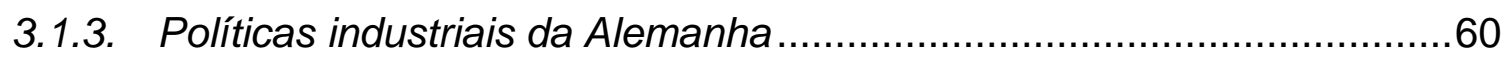

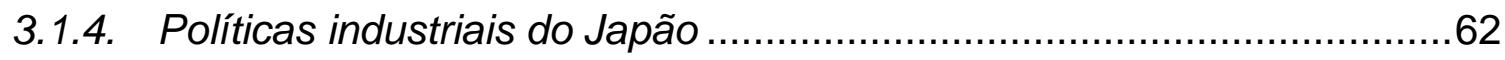

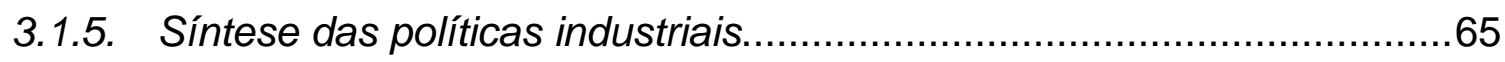

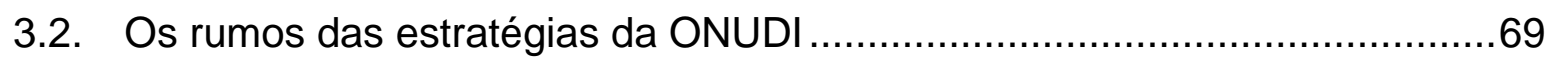

4. NOVAS POLÍTICAS INDUSTRIAIS E A TRANSFORMAÇÃO SOCIAL ...............77

4.1. A estratégia para o desenvolvimento e as novas políticas industriais ..........77

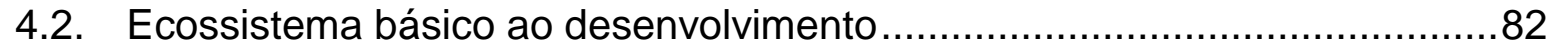

4.3. Proposta conjuntural ao desenvolvimento do ecossistema básico ..............87

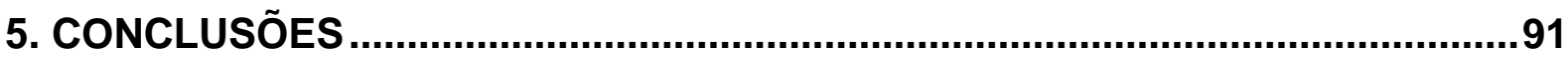

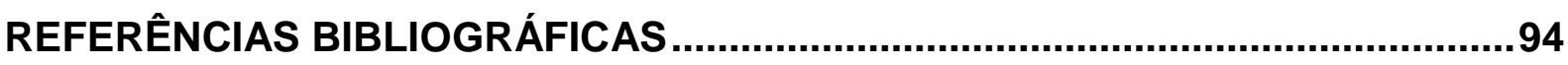




\section{APRESENTAÇÃO}

Ainda que as estratégias de promoção do desenvolvimento estejam distantes de um consenso entre especialistas, estimular o setor industrial de países em processo de desenvolvimento parece ser um instrumento coerente para a geração de emprego, renda e conhecimento. A Organização das Nações Unidas (ONU) reconhece que aprimorar o setor industrial é estratégia legítima e fundamental ao desenvolvimento dos Estados, o que estimulou a criação de uma agência dedicada ao tema.

Os projetos realizados pela Organização das Nações Unidas para 0 Desenvolvimento Industrial (ONUDI) tem amplo respaldo e aceitação pública internacional, além de contribuírem para a redução da pobreza e a inclusão social. Entretanto, as ações da ONUDI têm obtido pouco efeito na redução das crescentes desigualdades entre países desenvolvidos e em desenvolvimento.

A partir desta observação, a pesquisa busca comparar as políticas industriais de países desenvolvidos e os projetos de desenvolvimento do setor propostos a países em desenvolvimento pela ONUDI, identificando as principais diferenças. Como restrição à análise comparativa realizada, considerou-se a divergência de renda per capita entre países desenvolvidos e aqueles em processo de desenvolvimento. Desta forma, evidencia-se a necessidade da diferenciação entre as estratégias industriais para países desenvolvidos e aqueles em processo de desenvolvimento, por encontrarem-se em fases distintas de constituição econômica e social. É importante, portanto, que essa defasagem seja considerada pela ONUDI quando na elaboração de projetos de desenvolvimento industrial.

A pesquisa é composta por cinco capítulos, que contemplam, respectivamente, os seguintes temas:

Primeiro Capítulo - Apresenta-se o referencial teórico e metodológico da pesquisa, apontando-se os principais termos e conceitos relativos ao desenvolvimento industrial, ao revisitar as principais referências sobre o tema, o histórico de criação da ONUDI e o seu papel no desenvolvimento industrial de países em processo de desenvolvimento, bem como os determinantes de seus projetos de desenvolvimento industrial. 
Segundo Capítulo - Neste capítulo, analisa-se a questão da divergência de renda per capita entre os países desenvolvidos e aqueles em processo de desenvolvimento e a relevância da densidade industrial como fator estratégico ao desenvolvimento. Nesse contexto, aponta-se as principais tendências e dinâmicas econômicas e sociais da atualidade que impactam o setor industrial.

Terceiro Capítulo - Apresenta-se análise comparativa dos determinantes identificados em políticas industriais adotadas em países desenvolvidos selecionados e nos projetos da ONUDI, propugnados aos países em processo de desenvolvimento.

Quarto Capítulo - Propõe-se modelo de estrutura que contempla os determinantes a serem considerados para o desenvolvimento industrial em países em desenvolvimento.

Quinto Capítulo - Apresenta-se as conclusões da pesquisa, ao resgatar as principais análises acerca dos projetos de desenvolvimento industrial, para que sejam mais efetivas e sustentáveis no longo prazo. 


\section{REFERENCIAL TEÓRICO E METODOLOGIA}

\subsection{Introdução}

O perfil e a abrangência do setor industrial de um país refletem o seu nível de desenvolvimento econômico e social. As políticas públicas de fomento desse setor são, portanto, estratégicas para a redução da pobreza e a inclusão social em países que buscam promover seu desenvolvimento. Nos dias de hoje, entretanto, a promoção do desenvolvimento não depende apenas da visão estratégica que o país possui sob a ótica nacional, mas de fatores que extrapolam as suas fronteiras territoriais. Políticas de estímulo à inovação e ao conhecimento científico e tecnológico devem estar alinhadas às mais recentes tendências globais para que ampliem a agregação de valor nos bens produzidos e modernizem parques fabris, atendendo às mais exigentes demandas do mercado, interno e externo. A modernização constante do setor industrial deve figurar entre as estratégias de países em processo de desenvolvimento ${ }^{1}$, com o objetivo de aprimorar o setor privado e de gerar renda, empregos de qualidade e bem-estar social, algo presente e corriqueiro nas estratégias de países desenvolvidos.

A Organização das Nações Unidas para o Desenvolvimento Industrial (ONUDI), agência da ONU especializada no tema, tem como missão o incremento da capacidade produtiva de países em desenvolvimento e de menor desenvolvimento relativo, denominados na pesquisa como "em processo de desenvolvimento". Seus projetos abrangem a redução da pobreza, mediante incremento da capacidade produtiva; o estímulo de capacidades comerciais, por meio da ampliação de exportações qualificadas; a ampliação de matrizes energéticas limpas; o empoderamento das mulheres; a igualdade de gênero e; o fortalecimento de projetos de cooperação, Sul-Sul e triangular.

\footnotetext{
1 Para fins deste trabalho, entende-se que países em desenvolvimento e de menor desenvolvimento relativo são países em processo de desenvolvimento. De acordo com o "The Least Develop Countries Report 2014", elaborado pela Conferência das Nações Unidas para o Comércio e o Desenvolvimento (UNCTAD, na sigla em inglês), os países de menor desenvolvimento relativo são aqueles com maiores carências em termos de renda per capita, vulnerabilidade econômica (recursos naturais, comércio) e capital humano (nutrição, saúde, escolaridade). Ainda que mais carentes, são países em processo de desenvolvimento.
} 
Nota-se prontamente que as diretrizes da ONUDI buscam o aprimoramento do desenvolvimento econômico, social e ambiental dos países em processo de desenvolvimento. Entretanto, as desigualdades sociais crescentes entre nações ricas e pobres provocam questionamentos sobre as diretrizes aplicadas para 0 desenvolvimento do setor industrial de países em processo de desenvolvimento e sobre a estratégia adotada por agências especializadas, como a ONUDI, no que se refere à sua efetividade. Como consequência, questiona-se se diretrizes diversas das aplicadas poderiam ser também consideradas para a promoção do desenvolvimento desses países, que não apenas exportações qualificadas, empoderamento das mulheres, fortalecimento de projetos cooperativos ou ampliação de matrizes energéticas limpas.

Nos documentos da ONUDI analisados, identifica-se a busca pela convergência de renda ${ }^{2}$ entre os países desenvolvidos e aqueles em processo de desenvolvimento, no momento em que a agência se propõe a promover um desenvolvimento inclusivo e sustentável. Mesmo assim, alguns questionamentos tornam-se prementes, tendo em vista que os resultados auferidos até o momento não alcançam a esse objetivo e que as novas dinâmicas industriais em curso trazem novas realidades ao setor industrial.

Como construir projetos de desenvolvimento inclusivo e sustentável mais efetivos, por meio do fortalecimento dos setores industriais nacionais, no sentido de desencadear iniciativas disruptivas e em escala, promovendo o desenvolvimento econômico e social dos países em processo de desenvolvimento?

Chang (2008) relata detalhadamente como diversos países promoveram seu desenvolvimento, em diferentes períodos históricos, e que diretrizes consideraram para estimular o setor industrial e, assim, elevar de maneira plena e sustentável seus patamares econômicos e sociais. Além disso, o autor destaca que esses mesmos países desenvolvidos de hoje buscam manter o status quo no contexto global quando negociam diplomaticamente ou quando atuam em organizações internacionais especializadas, como a ONUDI, "chutando a escada".

\footnotetext{
${ }^{2}$ Convergência de Renda - debate econômico sobre as diferenças existentes entre a renda per capita dos países, regiões ou localidades. O debate cerca-se, via de regra, na aproximação (convergência) ou afastamento (divergência) da renda per capita de países em processo de desenvolvimento com relação a países desenvolvidos, assunto que será explorado em capítulo à parte ao longo da pesquisa.
} 
$\mathrm{Na}$ atualidade, diferentes tendências econômicas e sociais orientam a adoção de novas políticas, tanto em países desenvolvidos, como em processo de desenvolvimento. Entretanto, cada país no mundo encontra-se em uma fase de formação política, econômica e social distinta. Compreender essas tendências e correlacioná-las com a realidade de inserção internacional de cada país é pré-requisito básico à elaboração das estratégias de promoção do desenvolvimento. As políticas e os projetos industriais servem de instrumento à promoção do desenvolvimento, e a identificação de determinantes efetivos pode trazer consequências promissoras aos países que buscam aprimorar seu desenvolvimento no contexto globalizado e cada vez mais complexo da atualidade.

Reconhece-se que a tentativa de preservação do status quo por países desenvolvidos é algo esperado do jogo internacional da competitividade que todas as nações estão sujeitas. Considera-se relevante, entretanto, que as nações que buscam seu desenvolvimento identifiquem individualmente as respectivas capacidades de inserção internacional, bem como os determinantes necessários às suas políticas industriais, para que, então, elaborem estratégias customizadas ao seu desenvolvimento. Utilizando a metáfora de Chang (2008), é primordial que os governos percebam que cada país se encontra em diferente fase de desenvolvimento e, assim, deve identificar "seus degraus" e construir a "sua escada", independente do que orientam organizações internacionais ou adotam países desenvolvidos.

Essa percepção, necessária aos países em processo de desenvolvimento, depende da capacidade de autoanálise sobre sua realidade, podendo ser ponto de referência para o planejamento de seu desenvolvimento industrial de curto, médio e longo prazos. Além disso, as novas dinâmicas econômicas e sociais da atualidade ampliam ainda mais o desafio da busca por essa convergência de renda e inserção internacional dos países em processo de desenvolvimento, exigindo ainda mais capacidade crítica, analítica e criativa dos formuladores de políticas, que almejam a promoção do bem-estar social como um todo.

\subsection{A definição do objeto de estudo e o problema}

Essa dissertação foi motivada por uma série de estudos e de experiências profissionais do autor no desenvolvimento de setores industriais, de países em 
desenvolvimento e de menor desenvolvimento relativo, em organizações privadas nacionais e internacionais, com ou sem fins lucrativos. Parte, portanto, de um forte interesse pessoal em entender a promoção do desenvolvimento nas dimensões política, econômica e social, por meio do adensamento das capacidades industriais de países, e, segundo, da aspiração em contribuir na busca de alternativas à promoção do desenvolvimento, ao condicionar as atividades industriais a patamares mais sustentáveis e humanitários, em benefício de comunidades locais, regionais e globais.

Com tais elementos: experiência, interesse e aspiração surgiu o questionamento inicial, promotor da presente pesquisa, relativo as atuais diretrizes que orientam a construção de projetos de desenvolvimento industrial, promovidos por instituições nacionais e internacionais, com foco principal na ONUDI. Especificamente, o questionamento se refere à efetividade ${ }^{3}$ dos projetos de adensamento industrial em países em processo de desenvolvimento, em comparação com políticas adotadas por países desenvolvidos. Quais as políticas que estes últimos adotam, e quais as que os primeiros adotam? Para responder essas questões, buscou-se realizar análise comparativa entre as políticas industriais adotadas nacionalmente por alguns países desenvolvidos selecionados e o discurso da ONUDI. Com o avançar da pesquisa, passou-se a considerar, mais do que as políticas industriais, os determinantes adotados pelos países desenvolvidos para manter e ampliar sua densidade industrial.

Em resumo, a pesquisa e a revisão bibliográfica baseiam-se na resolução do seguinte questionamento preliminar:

Por que os projetos de desenvolvimento inclusivo e sustentável, por meio do fortalecimento dos setores industriais nacionais, não são mais efetivos, no sentido de desencadear iniciativas disruptivas e em escala, promovendo o desenvolvimento econômico e social de países em processo de desenvolvimento?

\footnotetext{
${ }^{3}$ A pesquisa tem por objetivo evidenciar diretrizes efetivas, que demandem o mínimo de recursos possíveis, para a elaboração de projetos de desenvolvimento de países em processo de desenvolvimento, por meio do estímulo do setor industrial.
} 
A citada análise comparativa entre as políticas adotadas por países desenvolvidos e as propugnadas pela ONUDI visam a identificação e a proposição de determinantes a essas últimas, com o objetivo de delinear "novas políticas industriais"4, que levem ao desenvolvimento efetivo das economias, mediante processo de convergência de renda em relação às nações desenvolvidas.

A revisão de literatura busca ampliar o escopo do conhecimento envolvido no desenvolvimento industrial para além da Gestão da Produção, como a Economia, as Ciências Políticas e Sociais, que se integram na perspectiva dos estudos do desenvolvimento. O objetivo é demonstrar que novas dinâmicas, econômicas e sociais, bem como novas diretrizes para o desenvolvimento industrial, são imprescindíveis à estruturação de políticas no setor, pois tendem a aprimorar a efetividade e a sustentabilidade dos objetivos a serem alcançados.

As diretrizes identificadas e propostas ao longo da pesquisa certamente não esgotam todas as possibilidades existentes ao desenvolvimento do setor industrial. Almeja-se, contudo, contribuir para a elaboração de novas análises, dinâmicas e formulações de políticas multidisciplinares, que venham a aprimorar o setor industrial, na busca do refinamento do desenvolvimento humano e social, cada vez mais inclusivo e sustentável.

\subsection{Objetivos}

\subsubsection{Objetivo geral}

O objetivo geral dessa dissertação é propor alternativas às políticas e aos projetos de desenvolvimento industrial elaborados para economias em processo de desenvolvimento, por meio da análise de políticas industriais utilizadas em países desenvolvidos e das diretrizes da principal organização internacional dedicada ao setor, a ONUDI.

\subsubsection{Objetivos específicos}

Como complemento, os objetivos específicos buscam:

\footnotetext{
${ }^{4}$ WARWICK, K.; NOLAN, A. (2014).
} 
(a) identificar conceitos, temas e referências sobre o desenvolvimento industrial,

(b) analisar as novas dinâmicas políticas, econômicas e sociais que podem influenciar a orientação das políticas e projetos de desenvolvimento industrial,

(c) identificar os determinantes do desenvolvimento industrial de países desenvolvidos e compará-los com as proposições da ONUDI,

(d) demonstrar que as orientações de organizações internacionais, em especial, no desenvolvimento industrial, podem ser aprimoradas, ao contemplar a estruturação de um ecossistema básico preliminar,

(e) propor um modelo conceitual à elaboração de políticas industriais que contemple três perspectivas: dos indivíduos, dos Estados e da sociedade internacional.

\subsection{Premissas}

O trabalho parte de duas premissas. A primeira considera que os projetos de desenvolvimento industrial elaborados pela ONUDI para países em processo de desenvolvimento não contemplam, em sua plenitude, as dinâmicas socioeconômicas nacionais e internacionais necessárias para a efetividade desses projetos.

A segunda refere-se ao fato de que o desenvolvimento industrial do século XXI será pautado por aqueles países que detiverem o conhecimento, o saber científico, tecnológico e de inovação, e que as políticas nacionais adotadas por países desenvolvidos podem ser uma referência aos países em processo de desenvolvimento, pois se encontram em fases distintas de formação política, econômica e social.

Os riscos possíveis para os países em processo de desenvolvimento que não perceberem as novas dinâmicas econômicas e sociais da atualidade e as diretrizes de estímulo do setor industrial são a ampliação de suas desigualdades internas, a maior divergência de renda com relação aos países desenvolvidos e o arrefecimento de seu processo de desenvolvimento. 


\subsection{As escolhas teóricas e metodológicas}

\subsubsection{Revisão de literatura - do Chute a Escada à Sociedade do Conhecimento}

Kupfer e Hasenclever (2013) destacam as diferentes teorias sobre a participação estatal no estímulo das capacidades produtivas. Os autores sintetizam as principais correntes entre ortodoxos, desenvolvimentistas e evolucionistas. Em linhas gerais, os ortodoxos questionam a intervenção estatal e o manejo do mercado; os desenvolvimentistas enfatizam o poder econômico e produtivo no cenário internacional, ao passo que os evolucionistas priorizam as capacidades dos agentes econômicos em promover inovações que venham a alavancar setores industriais.

De acordo com os autores, o conceito de "política industrial" pode ser expresso como:

O conjunto de incentivos e regulações associadas as ações públicas, que podem afetar a alocação inter e intraindustrial de recursos, influenciando a estrutura produtiva e patrimonial, a conduta e o desempenho dos agentes econômicos em um determinado espaço nacional. (KUPFER; HASENCLEVER, 2013, p.313)

O conceito exposto pode ser compreendido e extrapolado como o compilado de aprendizagens históricas, consideradas na elaboração de políticas e projetos industriais. Por exemplo, o crescimento asiático da década de 1980 demonstrou a necessária participação de instituições públicas no desenvolvimento socioeconômico dos Estados. Além disso, o avanço tecnocientífico conduziu a retornos crescentes de escala $^{5}$ que justificaram constantes intervenções estatais. Da mesma forma, a racionalidade limitada, os interesses múltiplos e a compreensão imperfeita da realidade interferiram, e ainda influenciam, principalmente, os países em processo de desenvolvimento na tomada de decisões políticas.

\footnotetext{
${ }^{5}$ Economias de escala - Quando o aumento do volume de produção (escala) de uma empresa, país ou região suscita a redução dos custos unitários. Economias internas de escala ocorrem quando a própria empresa constrói infraestruturas que permitem o aumento do volume produtivo; e externas de escala, quando os benefícios são decorrentes de serviços públicos que beneficiam a indústria ou setor.
} 
À margem do discurso entre liberalização e intervencionismo, os países desenvolvidos buscam, sobretudo, fortalecer a capacidade produtiva e competitiva de seu setor industrial, construindo políticas que abarquem fluxos de capital, bens, serviços e tecnologias. Kupfer e Hasenclever (2013) demonstram ainda que as políticas de países da Organização para a Cooperação e Desenvolvimento Econômico (OCDE) enfatizam medidas de apoio à capacidade de concorrência externa (auxílio às exportações, medidas setoriais e de suporte a empresas em dificuldades), de apoio às atividades de pesquisa e desenvolvimento $(\mathrm{P} \& \mathrm{D})$ e à difusão tecnológica e de apoio ao investimento fixo (financiamento em condições favoráveis).

Warwick (2013) seleciona algumas das inúmeras definições de política industrial no Quadro 1, ilustrando a variedade conceitual.

Conhecer as diretrizes estruturantes que compõem as políticas industriais é algo imprescindível aos países em processo de desenvolvimento, mas nada trivial. Afinal, identificar e parametrizar as diretrizes, para então propor políticas e projetos de estímulo ao setor industrial em países cujas carências básicas, baixos índices educacionais, infraestruturas deficientes, altos níveis de corrupção, burocracia excessiva, entre outros fatores, amplia ainda mais as dificuldades dessas nações ao planejar seu desenvolvimento. Além disso, novas dinâmicas econômicas e sociais globais influenciam cada vez mais a adoção de novas estratégias de desenvolvimento, por meio do estímulo do setor industrial.

Um setor industrial estruturado, diversificado e competitivo tende a elevar as exportações e substituir as importações, ao gerar superávits na Balança Comercial ${ }^{6} \mathrm{e}$ reduzir déficits em Transações Correntes ${ }^{7}$, minimizando suscetibilidades da economia à choques externos 8 . O desenvolvimento do setor depende, por fim, do nível de abertura econômica do país e dos adequados e constantes volumes de investimento e poupança.

\footnotetext{
${ }^{6}$ Balança comercial - Relação entre as exportações e as importações de um país.

7 Transações Correntes - Parte da Balança de Pagamentos de um país que contempla a Balança Comercial, a Balança de Serviços e as Transferências Unilaterais entre os Estados.

${ }^{8}$ Choques Externos - Impactos na economia resultantes de instabilidades externas.
} 


\section{Quadro 1 - Definições de política industrial}

OECD, 1975

Curzon-Price, 1981

Wachter and Wachter, 1981

Adams and Klein, 1983

Tyson and Zysman, 1983

Johnson, 1984

Graham, 1986

Geroski, 1989

Krugman and Obstfeld, 1991

Chang, 1994

Sharp, 1998

Foreman-Peck and Frederico, 1999

Beath, 2002

Rodrik, 2004

Aiginger and Sieber, 2005

Pitelis, 2006
"Industrial policies are concerned with promoting industrial growth and efficiency."

"Industrial policy may be generally defined as any government measure, or set of measures, to promote or prevent structural change."

"....the term industrial policy indicates the relationship between business and government on a microeconomic level..."

"....everything which is useful to improve growth and competitive performance."

"Industrial policy... means government policy aimed at or motivated by problems within specific sectors."

"Industrial policy means the initiation and co-ordination of governmental initiatives to leverage upward the productivity and competitiveness of the whole economy and of particular industries in it."

"Industrial policies refer to those policies intended to affect in some ways manufacturing or service industries."

"....a wide-ranging, ill-assorted collection of micro-based supply initiatives which are designed to improve market performance in a variety of occasionally mutually inconsistent ways."

"Industrial policy is an attempt by a government to encourage resources to move into particular sectors that the government views as important to future economic growth."

Industrial policy is one "aimed at particular industries (and firms as their components) to achieve the outcomes that are perceived by the state to be efficient for the economy as a whole."

Industrial policy "can be defined as any policy affecting the allocation of resources to industry and in this sense embraces both macroeconomic policy ... as well as the more traditional areas of microeconomic policy."

Industrial policy is "every form of state intervention that affects industry as a distinct part of the economy."

Narrow view: "Restrict attention to policies that target particular firms and industrial sectors."

Broad view: "any policy that shapes or influences the competitiveness of a country's firms and industries."

"...restructuring policies in favour of more dynamic activities generally, regardless of whether those are located within industry or manufacturing per se."

Industrial policy is "the activity which creates a favourable environment for European business in general, the manufacturing sector and its industries in specific."

"Industrial policy refers to a set of measures taken by a government and aiming at influencing a country's performance towards a desired objective."

Fonte: Aiginger (2007) e White (2008) apud Warwick (2013).

Os conceitos de política industrial acima enunciados deixam evidente o uso de políticas ativas nos estágios iniciais do desenvolvimento. Entretanto, cabe questionar se o avançar do processo de desenvolvimento não resulta em políticas de estímulo 
indireto, ampliando o espaço ao capital privado, ao empreendedorismo, ao desenvolvimento científico e tecnológico e à inserção internacional dos países.

Nesse contexto, a dissertação busca parametrizar as políticas industriais de países desenvolvidos e os projetos da ONUDI sob uma mesma matriz de análise desenvolvida por Sullivan et al. (2013). O resultado pretende embasar a proposição de novas políticas e diretrizes multidisciplinares (industriais, tecnológicas, comerciais), que venham também a contemplar e a solver as carências básicas ainda existentes nos países em processo de desenvolvimento.

Como ponto de partida, analisa-se o papel do Estado nos processos de desenvolvimento e industrialização, bem como série de estratégias nacionalistas e protecionistas, como, por exemplo, as destacadas por Chang (2008). O autor adota a expressão "chutar a escada" do economista alemão Friedrich List $^{9}$, que defendia o nacionalismo mercantilista e descrevia a postura imperativa dos países desenvolvidos como obstáculo ao desenvolvimento dos países em processo de desenvolvimento. Afinal, poderiam se tornar possíveis competidores aos países desenvolvidos.

A principal tese de Chang (2008) é a de que os países ricos de hoje atingiram os níveis atuais de desenvolvimento por terem adotado políticas econômicas protecionistas, as mesmas que eles atualmente condenam a adoção por parte dos países mais pobres. Uma vez no topo do desenvolvimento, os ricos então "chutam a escada" que os levou ao patamar superior, na busca da obstrução do desenvolvimento aos demais países, para que não sejam competitivos o suficiente a ponto de ameaçar sua supremacia.

Chang, além disso, alega que o Estado deve atuar contra a "mão invisível" do mercado, sendo necessário a "mão benevolente" do governo para o desenvolvimento. É, nesse sentido, segundo o autor, que os Estados devem adotar políticas protecionistas para atingir algum grau de desenvolvimento, para que só então tornemse mais liberais, mais ortodoxos ${ }^{10}$. Segundo Chang (2008), os países mais propensos

\footnotetext{
9 O "chute na escada" refere-se a uma metáfora empregada pelo economista alemão, Friedrich List, em sua obra de cunho nacionalista intitulada "O Sistema Nacional de Economia Política" de 1841. O economista alemão mostrou, com exemplos históricos, que os países que primeiro se desenvolviam "chutavam a escada" ou "puxavam o tapete" para impedir que os demais países Ihes fizessem concorrência.

${ }^{10}$ Privatizações, redução da burocracia, banco central menos politizado, combate à inflação, abertura comercial, equilíbrio orçamentário do governo são, segundo o autor, medidas prejudiciais aos países em processo de desenvolvimento.
} 
ao desenvolvimento são aqueles que conseguem se adaptar com maior facilidade às tendências globais do momento, desenvolvendo políticas industriais, comerciais e tecnológicas que venham mais a facilitar do que a comprometer a eficiência da burocracia governamental.

Todos os países atualmente desenvolvidos elaboraram e utilizaram políticas de proteção comercial, industrial e tecnológica ativas ao longo de sua formação, segundo o autor. Comprovando sua afirmação, utiliza seleção de dados históricos que buscam comprovar a tese. Em outra medida, demonstra que os países ricos de hoje adotaram diferentes etapas e estratégias de desenvolvimento com a utilização dessas políticas, argumentando em favor da inexistência de modelo único, algo também estimulado pelo Consenso de Washington ${ }^{11}$.

Um dos pontos altos da obra de Chang (2008) é a análise da "boa governança" como fator estrutural ao desenvolvimento dos Estados. Segundo o autor, a existência das políticas que hoje são recomendadas aos países em desenvolvimento são mais o resultado do que a causa desse desenvolvimento. Ainda, segundo o autor, existe correlação direta entre desenvolvimento e progresso político e institucional. Dessa forma, o autor reforça o argumento da construção política e institucional dos países, ao longo de seu processo de formação, enfatizando instituições como democracia, burocracia, poder judiciário, direitos de propriedade, governança empresarial, instituições financeiras públicas e privadas, previdenciárias e trabalhistas, que compõem em seu conjunto, um ecossistema básico ao desenvolvimento. Cabe destacar, contudo, que a adoção de políticas protecionistas por prolongado período de tempo tende a beneficiar grupos específicos de indivíduos em um determinado país, à custa do desenvolvimento de toda uma população, por vezes, desestruturando o crescimento econômico, social e até ambiental do país.

Chang (2008), entretanto, estabelece relação causal incompleta entre as políticas industrias e o desenvolvimento, pois tangencia fatores institucionais estratégicos, como os culturais e os educacionais, que sustentam a industrialização e

\footnotetext{
${ }^{11}$ Consenso de Washington - No início dos anos 1990, reuniões do Fundo Monetário Internacional (FMI), Banco Mundial e Tesouro dos Estados Unidos resultaram em uma série de recomendações econômicas ao mundo em desenvolvimento. As medidas buscavam estimular políticas de abertura comercial, de Estado mínimo, de privatizações de atividades produtivas, com o objetivo de cortar despesas e contornar os problemas da crise fiscal do período, como inflação intensa, déficits em contas correntes, crescimentos econômicos insuficientes e distorções na distribuição da renda.
} 
a transformação tecnológica de diversos países no mundo. Exemplo notório de desenvolvimento é a Coreia do Sul, que buscou a promoção de seu desenvolvimento com pesados investimentos na educação e no aprimoramento tecnológico do país, percebendo que esses poderiam ser um de seus principais ativos, perante a escassez de recursos naturais em seu território.

Mesmo assim, um ponto relevante da obra é a identificação de dois conjuntos de políticas, a industrial e a comercial, como as responsáveis pelo desenvolvimento dos Estados. Como exemplo, o autor destaca os subsídios, os incentivos fiscais, as proteções tarifárias e o dirigismo setorial entre as manobras de defesa de interesses. Neste ponto, o autor destaca a importância do planejamento "racional" ao longo da formação histórica dos Estados, quando demonstra acreditar ser possível a adoção de medidas políticas e econômicas, todas elas encadeadas e estruturadas no tempo, com objetivos expressos e pré-determinados para o desenvolvimento. Dificilmente, contudo, um país teria essa visão estratégica de longo prazo em momento tão conturbado como no período de processo de formação e desenvolvimento, conseguindo manter-se sempre no rumo, sem interferências políticas externas ou internas.

O autor contribui, sobretudo, ao enunciar sua máxima de que os países bemsucedidos são justamente aqueles que conseguem adaptar melhor suas políticas às mudanças globais, uma vez que seriam as políticas industriais, comerciais e tecnológicas as que separam os países desenvolvidos daqueles em busca de desenvolvimento. Além disso, salienta que instituições sólidas e sustentáveis possuem papel estratégico no desenvolvimento dos Estados.

Por fim, interrompe sua análise antes de apontar prospectivamente as principais tendências econômicas e sociais da atualidade, que tem afetado, tanto países desenvolvidos, como aqueles em busca de desenvolvimento.

\subsubsection{Tendências econômicas globais que afetam o setor industrial}

Inúmeros autores ${ }^{12}$ prescrevem uma nova dinâmica industrial na atualidade, com características que abarcam a grande dispersão das manufaturas pelo mundo,

\footnotetext{
12 Dani Rodrik, Joseph Stiglitz, Jorge Arbache, Ricardo Hausmann, entre outros.
} 
numerosas conexões transfronteiriças, linhas de produção de menor escala, produtos customizados, sobreposição de tecnologias, responsabilidade ambiental das empresas, maior abertura chinesa, inserção dos países em processo de desenvolvimento às cadeias globais de valor, dinâmicas de arranjos produtivos locais colaborativos, inovação constante, entre outras características.

$\mathrm{Na}$ história recente, o interesse em estimular as manufaturas ganhou fôlego após a crise econômica e financeira de 2008, quando a bonança monetária e especulativa no mercado imobiliário norte-americano atuou como o estopim para severos impactos na economia mundial. A crise provocou séria recessão e resultou no estímulo monetário e no dirigismo estatal em diversos países, na busca pela contenção dos efeitos da crise e retardamento de um possível colapso econômico momentâneo. Desde então tem perseverado forte debate sobre as possíveis estratégias de desenvolvimento a serem empregadas pelos países, em grande medida conduzidas por setores produtivos tradicionais como o manufatureiro, afastando o ambiente meramente especulativo na economia do desenvolvimento.

Esse novo fôlego industrial traz, por conseguinte, uma aparente oportunidade de desenvolvimento econômico, social e inclusivo aos países em processo de desenvolvimento, pois privilegia os detentores de conhecimento científico, tecnológico e inovador, em grande medida liderado pelos países desenvolvidos e industrializados.

Segundo Stiglitz e Greenwald (2014):

Earlier, we emphasized that what separates developed from developing countries is not just a gap in resources, but a gap in knowledge. Much of the difference in per capita income between these countries and the more advanced is attributable to differences in knowledge. If this is so, then development strategies should be centered on promoting learning, closing the knowledge gap between more- and less-developed countries. Policies that transformed their economies and societies into "learning societies" would enable them to close the gap more rapidly, with market increases in incomes. Development entails learning how to learn. As we argued earlier too, the fact that some countries and firms have "learned how to learn" helps explain why the last two centuries have seen such remarkable increases in standards of living, 
in comparison to the millennia that preceded them, which were marked by stagnation. (STIGLITZ; GREENWALD, 2014, p. 372, grifo nosso)

Os países em processo de desenvolvimento que não perceberem as novas dinâmicas globais da atualidade perderão dinamismo a longo prazo, desacelerando notavelmente suas economias e ampliando as desigualdades. A limitação dessa oportunidade acabará, mais uma vez, por privilegiar os países que já possuem vantagens em termos de conhecimento científico, tecnológico e inovador, restringindo a ascensão daqueles que não adotarem políticas em prol da geração interna de conhecimento.

Os países distraídos à essa nova dinâmica continuarão a buscar a produção industrial de massa e focar em uma agenda de redução de custos produtivos, quando o que deveria ser privilegiado é a produção personalizada, econômica e dedicada aos interesses dos consumidores. Novas tecnologias têm permitido essa individualização de bens de consumo e produção, comprovando a cada vez mais próxima realidade entre a unidade produtiva e o mercado, entre a fábrica e seu consumidor. Nesse sentido, os países hoje desenvolvidos e detentores de conhecimento levarão vantagem sobre os demais países, pois além de visarem, em grande medida, a aquisição de conhecimento científico e tecnológico, já buscam direcionar suas cadeias produtivas ao minimalismo do mercado personalizado, reduzindo perdas e atendendo às mais diversas demandas existentes. Por essas e outras razões que o território dos países desenvolvidos volta a atrair e a estimular os processos de manufatura, com vistas ao seu próprio desenvolvimento.

Em outra medida, como apontado em farta bibliografia, o crescimento da renda não é homogêneo em todos os países, já que os mais industrializados e detentores de conhecimento tecnocientífico se desenvolvem de forma mais dinâmica que os demais. Nesse sentido, o desconhecimento dos países em processo de desenvolvimento sobre as novas dinâmicas industriais existentes e a pouca detenção de conhecimento (científico, tecnológico e inovador) provocará uma ampliação dos diferenciais de renda per capita entre as nações e frustrará, consequentemente, os objetivos de desenvolvimento econômico e social. Em grande medida, a diferença entre o nível de desenvolvimento de países em processo de desenvolvimento e países desenvolvidos se acentuará, à medida que o conhecimento for gerado e disseminado 
no território dos países que detiverem centros tecnológicos, sedes de grandes empresas transnacionais e polos de desenvolvimento científico.

Sob ótica diversa, uma nova sistemática pós-industrial de aparente desindustrialização de alguns países desenvolvidos tem adquirido relevo. O que ocorre, sobretudo, é a transição da dinâmica produtiva-industrial, para um novo ambiente, no qual o setor industrial atua em sinergia com o setor de serviços. Essa dinâmica é intensificada em países desenvolvidos, quando priorizam a constante agregação de valor baseado no conhecimento, em serviços como pesquisa e desenvolvimento, design, marketing, entre outras atividades correlatas. É por isso que as mais avançadas indústrias estão consumindo, cada vez mais, serviços, o que amplia a importância do setor para a agregação de valor e o consequente desenvolvimento dos Estados.

Essa aparente desindustrialização que ocorre em países desenvolvidos, corresponde, na verdade, a uma transição para ambientes produtivos mais sofisticados, inovadores, baseados no conhecimento e na maior densidade industrial $^{13}$. Cabe, portanto, aos países em processo de desenvolvimento perceber as novas dinâmicas que ocorrem na atualidade, para que não percam mais oportunidades ao aprimoramento de seu desenvolvimento político, econômico e social.

\subsubsection{ONUDI e suas diretrizes}

No sentido de dar celeridade ao desenvolvimento dos países que o estão buscando, por meio do estímulo do setor industrial, a Assembleia Geral das Nações Unidas (ONU) criou a Organização Industrial para o Desenvolvimento Industrial (ONUDI), em novembro de 1966, por meio da resolução de número 2152 (XXI). A nova organização passava a ser a principal instância, no âmbito da ONU, dedicada à promoção e ao estímulo do setor industrial de países emergentes e de menor desenvolvimento relativo.

Em 1975, em Lima, no Peru, um grupo de Estados adotou a Declaração de Lima sobre o Desenvolvimento Industrial e Cooperação, que tinha como objetivo

\footnotetext{
${ }^{13}$ A questão da densidade industrial é analisada mais detidamente no próximo capítulo.
} 
principal elevar a participação de países emergentes e de menor desenvolvimento relativo na produção industrial mundial. Além disso, a Declaração abriu caminho para que a ONUDI se tornasse uma agência especializada no âmbito da ONU em 1985, o que garantia maiores prerrogativas, tanto econômicas quanto políticas à instituição.

Em 1997, os Estados-Membros da agência adotaram o "Business Plan for the Future Role and Functions of UNIDO'14", documento que formalizava a reestruturação completa da instituição, afinal, a agência precisava responder e enfrentar as mudanças econômicas globais daquele período histórico, como a Crise Mexicana em $1994^{15}$, a Crise Asiática em $1997^{16}$ e a Crise Russa em $1998^{17}$. Essa reestruturação temática fez com que a agência viesse a dar maior ênfase ao desenvolvimento do setor privado nos países em que atuava.

Em 2013, na mesma cidade de Lima, a agência adotou um novo Mapa do Caminho que lista as prioridades da instituição para as próximas décadas, celebrando a Nova Declaração de Lima. A Nova Declaração de Lima sobre a Cooperação e o Desenvolvimento Industrial enfatiza a necessidade de que o desenvolvimento industrial seja inclusivo e sustentável, além de estimular a participação de países em desenvolvimento e de menor desenvolvimento relativo na produção industrial global. A declaração enfatiza que o desenvolvimento industrial inclusivo e sustentável tende a estimular o crescimento econômico e social, a criação de empregos decentes, a transferência e a absorção tecnológica, a pesquisa e o desenvolvimento e a ampliação da produtividade.

Em adição, a Declaração de Lima de 2013 ainda especifica as prioridades temáticas nas quais a agência possui vantagens comparativas e notório conhecimento, como capacitação produtiva e comercial, eficiência de recursos e produção sustentável.

\footnotetext{
${ }^{14}$ Business Plan for the Future Role and Functions of UNIDO - Plano de trabalho de 1997 da ONUDI que enunciava prospectivamente as atividades e programas da agência aos anos subsequentes.

${ }^{15}$ Crise Mexicana (1994) - Crise cambial sofrida pelo México no final do ano de 1994, em função de fortes déficits em seu balanço de pagamentos, fuga de capitais e desvalorização do peso mexicano.

${ }^{16}$ Crise Asiática (1997) - Crise na Ásia em meados de 1997 que provocou forte desvalorização das moedas no continente, interrupção do crescimento econômico dos países da região, queda das bolsas de valores e até de governos, como na Indonésia em 1998.

17 Crise Russa (1998) - Crise ocorrida na Rússia no final da década de 1990 provocada em grande medida pela acelerada transição do país de uma economia planificada para uma economia de mercado, o que provocou forte desvalorização da moeda, declaração de moratória e renegociação da dívida externa do país.
} 
Estudos recentes ${ }^{18}$ da agência também demonstram que a instituição procura estar em linha com as dinâmicas econômicas e sociais contemporâneas, como, por exemplo, processos de urbanização e crescimento populacional, por que passam, em especial, diversos países africanos; o menor emprego de recursos produtivos na produção de bens e serviços com qualidade; menores emissões de poluentes e redução de desperdícios ao longo da cadeia industrial.

A publicação Introduction to UNIDO, de 2014, enuncia que o objetivo principal e atual da agência é a promoção do desenvolvimento industrial em patamares mais inclusivos e sustentáveis, por meio da:

\section{(1) redução da pobreza, com o aprimoramento das atividades produtivas} - a agência desenvolve uma gama de serviços customizados às demandas dos países em desenvolvimento e de menor desenvolvimento relativo, desde suporte no desenvolvimento de políticas industriais, ao estimular o empreendedorismo e o desenvolvimento de pequenas e médias empresas, e disseminação de novas tecnologias, ao estimular a sustentabilidade no âmbito industrial e o abastecimento energético renovável. Ao adotar tais práticas, a agência atua em conformidade com os Objetivos de Desenvolvimento do Milênio $(\mathrm{ODM})^{19}$ de $\mathrm{n}^{\circ}$ 1, erradicar a extrema pobreza e a fome; de $\mathrm{n}^{\circ} \mathrm{0}$, promover a igualdade entre os sexos e estimular a autonomia das mulheres e de no 8 , estimular uma parceria mundial para o desenvolvimento.

(2) capacitação comercial - demonstração clara, segundo a agência, de que a integração dos países emergentes nas redes internacionais de comércio é fator estratégico fundamental para o desenvolvimento. Ao atuar com esta orientação a agência assessora países emergentes e de menor desenvolvimento relativo na aquisição de capacidades comerciais clássicas, ao incrementar a qualidade produtiva e a competitividade industrial. Além disso, a ONUDI capacita tecnicamente unidades produtivas nos países em normas

\footnotetext{
18 UNIDO (2013a).

19 Objetivos de Desenvolvimento do Milênio - Declaração internacional celebrada por 189 países em 2000, no âmbito das Nações Unidas, com o objetivo de endereçar 8 objetivos até 2015. No ano de 2010, os países renovaram o compromisso, a fim de acelerar a promoção do desenvolvimento.
} 
internacionais de qualidade e de metrologia, ao agregar valor aos produtos exportados pelos países em desenvolvimento.

(3) manutenção energética e ambiental - possuir acesso a recursos energéticos é necessidade básica para a promoção do desenvolvimento e para redução da pobreza extrema. Nesse sentido, a agência busca promover formas sustentáveis de consumo e de produção, como provedora de assistência na implementação de acordos ambientais internacionais e facilitadora de serviços ao uso energético eficiente e eficaz, com sustentabilidade. Ao promover novos padrões energéticos sustentáveis, a agência atua em conformidade com o Objetivo do Milênio de nำ 7, que busca garantir a sustentabilidade ambiental.

(4) incremento da cooperação Sul-Sul e triangular e promoção da igualdade de gênero - a cooperação Sul-Sul é uma das ferramentas adotadas pela agência para a promoção do desenvolvimento industrial entre "iguais", quando facilita o intercâmbio de experiências e conhecimentos tecnológicos e investimentos entre países emergentes do hemisfério Sul, através de seus governos, organizações da sociedade civil e academia. Trata-se de uma forma de cooperação sem condicionalidades e sem qualquer ingerência nos assuntos internos dos Estados. A cooperação triangular, por sua vez, é o resultado da cooperação técnica entre dois ou mais países do hemisfério Sul, mas suportada financeiramente ou tecnicamente por algum país desenvolvido, do hemisfério Norte, ou por alguma organização internacional. A agência ainda atua na promoção da igualdade de gênero e no empoderamento das mulheres nos setores produtivos locais e regionais, ao ampliar a qualificação, a inclusão e a participação das mulheres no mundo em desenvolvimento.

Mesmo assim, ainda fica a dúvida se as diretrizes empregadas pela ONUDI, em seus projetos de promoção do desenvolvimento em países emergentes e de menor desenvolvimento relativo, são as mais efetivas, o que traz como consequência outra questão: o que pode ser adicionado às estratégias da agência? 


\subsubsection{Método de pesquisa}

O método de pesquisa foi estruturado em quatro etapas, conforme esquematizado na Figura 1 abaixo. A pesquisa tem por objetivo propor alternativas às políticas e aos projetos de desenvolvimento industrial elaborados para economias em processo de desenvolvimento, tendo como foco de análise as políticas e os projetos de estímulo do setor industrial.

Figura 1 - Esquema representativo do método de pesquisa

\section{(1) Análise Teórica das Políticas Industriais}

(2) Identificação das Tendências Econômicas Globais

(3) Identificação das diretrizes utilizadas por países desenvolvidos e pela ONUDI

(4) Proposiçāo de alternativas às políticas e aos projetos de desenvolvimento industrial, ao considerar:

Ecossistema Básico Indivíduo - Estado - Mundo

Fonte: elaborado pelo autor.

Para alcançá-lo, a primeira etapa da pesquisa é constituída pela análise das teorias de desenvolvimento consideradas na bibliografia especializada em políticas industriais. Para cumprir esta etapa, orienta-se pelos procedimentos utilizados em uma pesquisa exploratória, buscando a familiaridade com o problema, por meio de levantamento bibliográfico e análise de exemplos que ampliam a compreensão sobre o tema. Como resultado, a pesquisa buscou percorrer a bibliografia a respeitos das políticas industriais e sintetizar os principais determinantes, incluindo aspectos políticos, econômicos e sociais existentes no desenvolvimento dos países selecionados. 
A segunda etapa contempla a identificação das principais tendências econômicas globais, com o objetivo de aprimorar a proposição final de alternativas às políticas e aos projetos de desenvolvimento industrial.

Para ilustrar as diretrizes utilizadas em projetos de desenvolvimento industrial, a terceira etapa analisa as políticas industriais dos seguintes países selecionados: Estados Unidos, Reino Unido, Alemanha e Japão, sob o modelo de análise matricial desenvolvido por Sullivan et al. (2013). Nesta etapa, são analisadas também as diretrizes da ONUDI em documentos oficiais, publicações técnicas, avaliações, declarações e acordos celebrados na última década, com o objetivo de identificar empiricamente as diretrizes que a organização busca promover em projetos de desenvolvimento industrial em países em processo de desenvolvimento. Além disso, objetiva revelar deficiências nos projetos da agência, quando em comparação com as novas dinâmicas econômicas e sociais da atualidade e com as políticas industriais dos países selecionados.

Para identificar as deficiências nos projetos da agência, essa etapa compara os determinantes das políticas industriais dos países desenvolvidos com as diretrizes adotadas pela ONUDI. Como resultado, identifica-se novas orientações para as políticas e os projetos de desenvolvimento industrial em países em processo de desenvolvimento, que contemplem aspectos contemporâneos do desenvolvimento, nas dimensões política, econômica e social.

Essa análise comparativa permite, sobretudo, especificar os componentes estratégicos utilizados pelos países desenvolvidos em suas políticas industriais e colocar em perspectiva a eventual aptidão dos países em processo de desenvolvimento em adotá-los, pois se encontram em níveis distintos de formação política, econômica e social. Afinal, possuem ecossistemas socioeconômicos básicos distintos.

$\mathrm{Na}$ quarta e última etapa, a pesquisa busca identificar as diretrizes imprescindíveis ao desenvolvimento, por meio do estímulo do setor industrial. $O$ objetivo é orientar o desenvolvimento de alternativas às políticas e aos projetos de desenvolvimento industrial, ao considerar a necessidade de estruturação deste ecossistema socioeconômico básico e as demandas em três perspectivas, do indivíduo, do Estado e do sistema internacional. 


\section{2. $O$ SETOR INDUSTRIAL COMO ESTRATÉGIA PARA DESENVOLVIMENTO}

\subsection{Reindustrialização dos industrializados e a importância das manufaturas}

O setor industrial vem passando por profundas transformações em razão das mudanças nos padrões de consumo, das novas tecnologias de produção e da integração dos mercados globais. Além disso, o setor industrial passa por processo de crescente relação simbiótica e sinergética com o setor de serviços para a agregação de valor, o que cria novos e diferentes empregos, gerando riquezas.

O papel do setor industrial para o desenvolvimento tem sido renovado, no momento em que os países intensificam estudos sobre o impacto das manufaturas na balança comercial e aumentam a eficiência e a produtividade do setor, adquirindo ganhos de competitividade.

As regiões e os países, entretanto, divergem sobre os objetivos almejados e os resultados adquiridos com 0 adensamento do setor produtivo. Para os Estados Unidos, por exemplo, as políticas governamentais de estímulo ao setor industrial estimulam a criação de um locus ao desenvolvimento de novas tecnologias, de novos setores e, principalmente, para a manutenção da segurança nacional ${ }^{20}$. Na grande maioria dos países europeus, fortalecer as manufaturas é a estratégia adotada para a alavancagem da recuperação econômica do continente, inclusive com a geração de novos empregos qualificados.

$\mathrm{Na}$ Ásia, o setor industrial representa, em grande medida, o aprofundamento tecnológico dos países e a manutenção da expansão e crescimento econômico, ao passo que, na América Latina, as manufaturas ganham relevo quando se almeja a preservação e o melhor uso dos recursos naturais, para a diversificação tecnológica e a promoção do desenvolvimento regional. Compreender os resultados alcançados com o fomento da indústria e as novas dinâmicas que influenciam o setor são estratégias fundamentais para a formulação de políticas adequadas ao desenvolvimento dos Estados.

20 Mazzucato (2014). 
O entendimento do nível de desenvolvimento industrial de um país, no contexto de sua inserção tecnológica internacional, não é suficientemente disseminado. A figura abaixo, procura ilustrar o que se chama de "espaço-indústria", isto é, o nível de desenvolvimento industrial dos países, por meio da variável "densidade industrial", calculada como o valor adicionado da indústria de transformação dividido por sua população total. Essa variável - densidade industrial - reflete a disponibilidade de recursos existentes no país que contribuem para a agregação de valor ao produto manufaturado, como recursos humanos qualificados, existência de centros de P\&D no país, polos de ciência, tecnologia e inovação (CT\&I), instituições sólidas e infraestruturas adequadas.

A densidade industrial reflete, sobretudo, a existência no país de um ecossistema básico propício ao desenvolvimento político, econômico e social, por meio da disponibilidade de recursos diretos e indiretos que estimulam ou desestimulam o setor.

Figura 2 - A dinâmica do desenvolvimento industrial

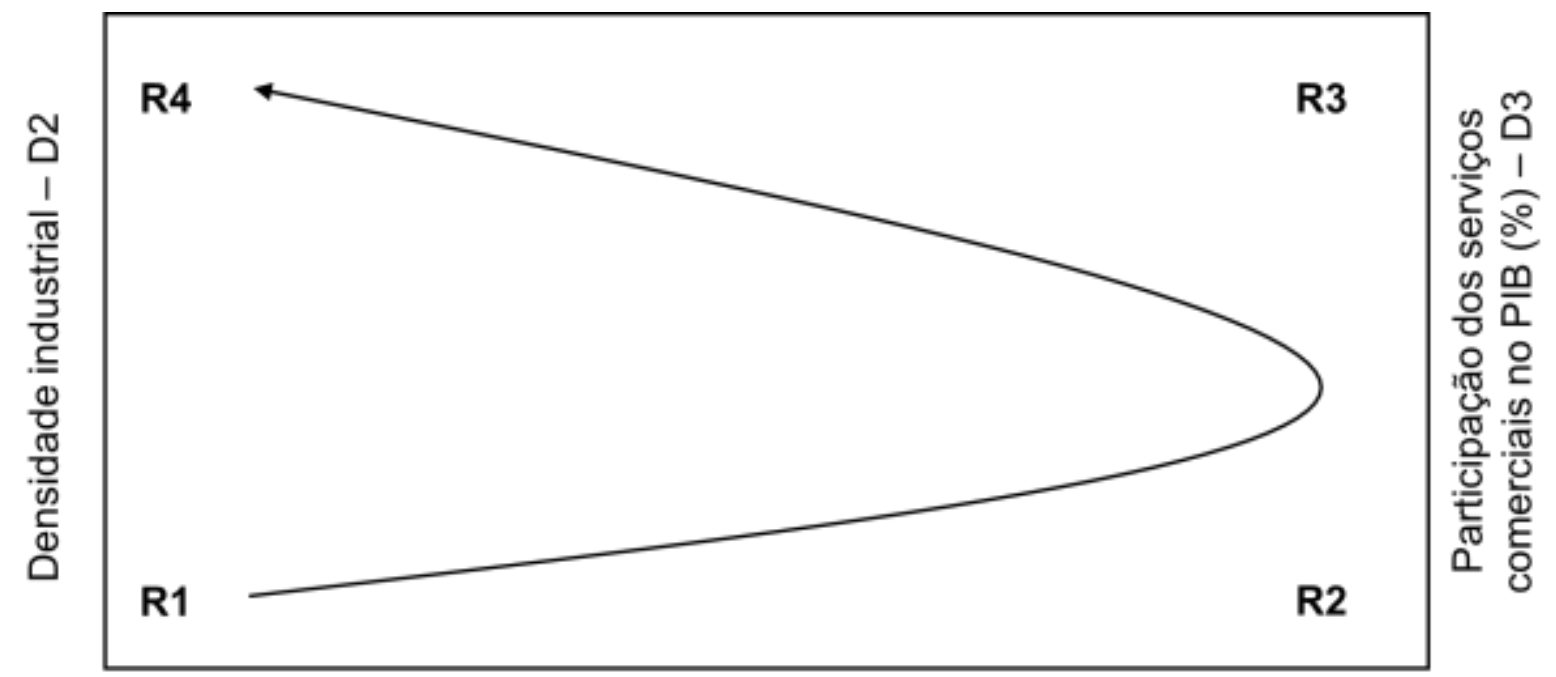

Participação da indústria no PIB (\%) - D1

Fonte: Arbache (2014).

Arbache (2014) destaca que o "espaço-indústria", representado na figura 2, possui três dimensões de análise, sendo a participação da indústria no valor adicionado, D1; a densidade industrial, D2; e a participação dos serviços comerciais no PIB, D3. Via de regra, os países iniciam a trajetória do desenvolvimento industrial próximos à região $\mathrm{R} 1$, momento em que a participação da agricultura no PIB é alta e 
a industrial é baixa e os produtos básicos, sem agregação de valor ou de serviços, representam a maior parte da cartela produtiva doméstica.

A busca por melhores condições de vida nos grandes centros urbanos e 0 processo de urbanização provoca 0 aumento da demanda por produtos industrializados, deslocando os países da região $\mathrm{R} 1$ para a região $\mathrm{R} 2$, pois aumenta a participação da indústria no PIB. Essa região (R2) é o estágio em que os países desenvolvem suas indústrias de base, manufaturas de baixo valor agregado e serviços básicos.

A grande maioria dos países em processo de desenvolvimento encontra-se no trecho R1-R2, pois não perceberam que adentrar regiões como R3 ou R4 exige a compreensão das novas dinâmicas econômicas e sociais e a consequente estruturação das políticas industriais para esta nova realidade. Adentrar a região R3 e, por conseguinte a região $\mathrm{R} 4$, exige dos países a compreensão da necessidade de uma inflexão no estímulo do setor industrial para a promoção do desenvolvimento econômico e social. Em outras palavras, para sair de R2 e rumar para a região R3, é imprescindível que o setor industrial dos países em processo de desenvolvimento venha a adquirir uma relação simbiótica e sinergética com novas dinâmicas produtivas, como a maior participação dos serviços nos sistemas produtivos.

Deslocar-se para R3 é ampliar a densidade industrial, é produzir mais, com melhor qualidade e produtividade, mas com o emprego de menos recursos, menos mão de obra e menos tempo. Em outra medida, rumar para R3 é ampliar a participação dos serviços comerciais na economia, ao passo que ocorre um aparente declínio da participação relativa da indústria no PIB, quando, na verdade, o setor industrial torna-se mais denso, pois agregou novas dinâmicas que essa sociedade baseada no conhecimento e na inovação exigem cada vez mais.

Não é incomum vermos países com setores industriais completamente diferentes apresentarem índices de participação da indústria no PIB semelhantes. No Brasil, por exemplo, a participação da indústria no PIB é de $23,4 \%$ em 2014, enquanto nos Estados Unidos é de 20,5\% em 201321. A diferença está no fato de que o Brasil está entre a região $\mathrm{R} 1-\mathrm{R} 2$ e os Estados Unidos está entre a região R3-R4, demonstrando que o país norte-americano possui uma densidade industrial que o

\footnotetext{
21 World Bank, Industry, value added (\% GDP). Acessível em: http://data.worldbank.org/indicator/NV.IND.TOTL.ZS
} 
destaca no contexto internacional. Por isso, o declínio da participação relativa da indústria no PIB não representa que a indústria passa a perder relevância no contexto do desenvolvimento do Estado, mas sim que o setor passou a ser mais sofisticado, mais denso, mais propício ao estímulo do desenvolvimento via agregação de conhecimento.

A região de $\mathrm{R} 4$, por fim, é caracterizada pela pequena participação da indústria no PIB, mas também de uma indústria altamente qualificada, baseada na inovação e no conhecimento agregado aos produtos. Por outro lado, a região também é caracterizada pela alta sofisticação dos serviços agregados ao setor industrial, como, por exemplo, uso de big data, internet das coisas, cloud computing, desenvolvimento de softwares, manufaturas avançadas, além de intensos investimentos em pesquisa, desenvolvimento e inovação (PD\&l).

A dinâmica do "espaço-indústria" revela que o setor industrial passa por um processo de profunda transformação, algo que deve ser percebido e internalizado nas políticas e projetos realizados pelos países em processo de desenvolvimento. A natureza dos produtos industriais e dos serviços está cada vez mais interconectada, as demandas mercadológicas mais customizadas, as relações entre capital e trabalho

mais difusas. É por isso que as dinâmicas de crescimento econômico e social têm sido questionadas, bem como as definições de bens, serviços e as formas de mensuração da produção industrial. Cabe, portanto, aos países em processo de desenvolvimento estarem atentos às novas dinâmicas da atualidade, para que aprimorem o seu desenvolvimento e minimizem as desigualdades internas e externas.

\subsection{As tendências econômicas globais e o setor industrial}

O contexto socioeconômico contemporâneo passa por processo de transformação, com a disseminação da globalização, a crescente interdependência entre as economias, a emergência chinesa, a maior influência dos governos nacionais no manejo de suas economias, as novas tecnologias de produção e de organização fabril e o crescente protagonismo do setor de serviços na geração de riqueza, com a intensificação da pesquisa, do desenvolvimento e da inovação em diversos parques industriais espalhados pelo mundo. Soma-se a essas tendências, o fato de que diversos países desenvolvidos e industrializados estão atraindo novamente as 
atividades de cunho manufatureiro para seus territórios, suplantando a estratégia anterior de terceirizar as etapas produtivas, principalmente aos países asiáticos, na busca por mão de obra barata.

Ainda que os custos da mão de obra em países desenvolvidos, como nos Estados Unidos, por exemplo, continuam a ser elevados, quando em comparação com os existentes em países em processo de desenvolvimento, essa não tem sido mais a principal estratégia adotada para adquirir competitividade no meio industrial. Os benefícios fiscais ao desenvolvimento de sofisticadas tecnologias, a elevada produtividade do trabalho, as adequadas infraestruturas presentes nos países desenvolvidos e, sobretudo, a percepção de que, para desenvolver novas tecnologias e inovações é necessário estar próximo das linhas fabris, para testar e validar novos produtos, têm compensado o diferencial de custos - mão de obra - e contribuído para reaproximar as manufaturas aos territórios daqueles que querem operar na fronteira do conhecimento e do desenvolvimento.

Em outra medida, os custos de mão de obra em países como a China têm aumentado, tendo em conta a priorização de programas de desenvolvimento científico e tecnológico, com vistas à agregação de valor. Nesse contexto, diversas empresas, que ainda possuem o custo da mão de obra como fator estratégico à competitividade, acabam por deslocar suas manufaturas para outros países ainda baratos em mão de obra, como Vietnã, Indonésia e Bangladesh, dando alguma oportunidade ao desenvolvimento desses novos países, pois atraem novos empregos. Entretanto, os governos nacionais desses países devem perceber o contexto em que estão inseridos nas dinâmicas globais, para que consigam gerar no futuro empregos de qualidade e, sobretudo, conhecimento em seu território.

No campo energético, novas fontes de energia, novas tecnologias de produção, de conservação e de eficiência energética adensam a competição produtiva nos mercados. Os Estados Unidos, um dos maiores importadores de energia do mundo até recentemente, passa a ser, nos últimos anos, um dos maiores produtores de hidrocarbonetos do mundo, com a exploração de gás e óleo de xisto. Por outro lado, diversos países europeus buscam priorizar energias limpas, como a eólica, a solar e a biomassa, adotando estratégias diferentes. A revolução energética gera, cada vez mais, impactos no dimensionamento do setor industrial, trazendo consequências 
deletérias aos países do mundo em desenvolvimento, dependentes ou carentes de planejamento, em termos de geração e produção de energia.

$\mathrm{Na}$ economia global, existe também uma constante percepção de "encurtamento" do tempo, frente a velocidade em que ocorrem mudanças econômicas, sociais e ambientais, e essas se sobrepõem no tempo. Além disso, as mudanças da atualidade comprovam a inevitável relação de causa e efeito de qualquer ação política entre diferentes países no mundo. A economia global torna-se cada vez mais complexa e menos previsível, e o desenvolvimento dos países uma tarefa ainda mais desafiadora.

Arbache (2015) sintetiza algumas dessas tendências na questão da divergência de renda entre países desenvolvidos e aqueles em processo de desenvolvimento.

Entre 1960 e 2000, a desigualdade da renda per capita entre os dois grupos de países permaneceu elevada e até aumentou. A partir de 2001, a desigualdade começou a cair lentamente, movimento que se acelerou entre 2003 e 2009, estabilizando-se a partir de então. Dentre as causas da queda da desigualdade destacam-se o crescimento dos preços das commodities, o aumento da renda na China e a crise financeira de 2008 , que afetou profundamente a renda dos países ricos.

Infelizmente, as previsões sugerem que o hiato de renda voltará a aumentar, especialmente quando isolamos a China dos demais países em desenvolvimento. Dentre as razões para isto estão a tecnologia e o padrão de comércio e de investimentos. (ARBACHE, 2015, p.2)

A questão da divergência de renda e a atual divisão do trabalho entre os países são resultados das dinâmicas econômicas que trazem consequências à constituição do setor industrial, tanto aos países em processo de desenvolvimento como desenvolvidos. Aos primeiros cabem, em grande medida, às atividades de produção, montagem, logística, distribuições e serviços de baixo valor agregado, como call centers, por exemplo. Enquanto aos últimos, cabem as atividades de alta agregação de valor, como pesquisa, desenvolvimento e inovação (PD\&l), design, marketing, pósvendas e demais serviços sofisticados. A figura abaixo ilustra essa divisão da produção por agregação de valor na economia mundial. 
A Smiley Face Curve, gráfico originalmente proposto pelo fundador da $\mathrm{Acer}^{22}$, Stan Shih, por volta de 1992, e sintetizada por Arbache (2014), organiza as atividades industriais em formato sequencial. De acordo com a agregação de valor, as extremidades da curva concentram as atividades industriais de maior valor agregado, ao passo que no centro ficam as etapas produtivas de menor agregação de valor.

\section{Figura 3 - Smiley face curve de países desenvolvidos}

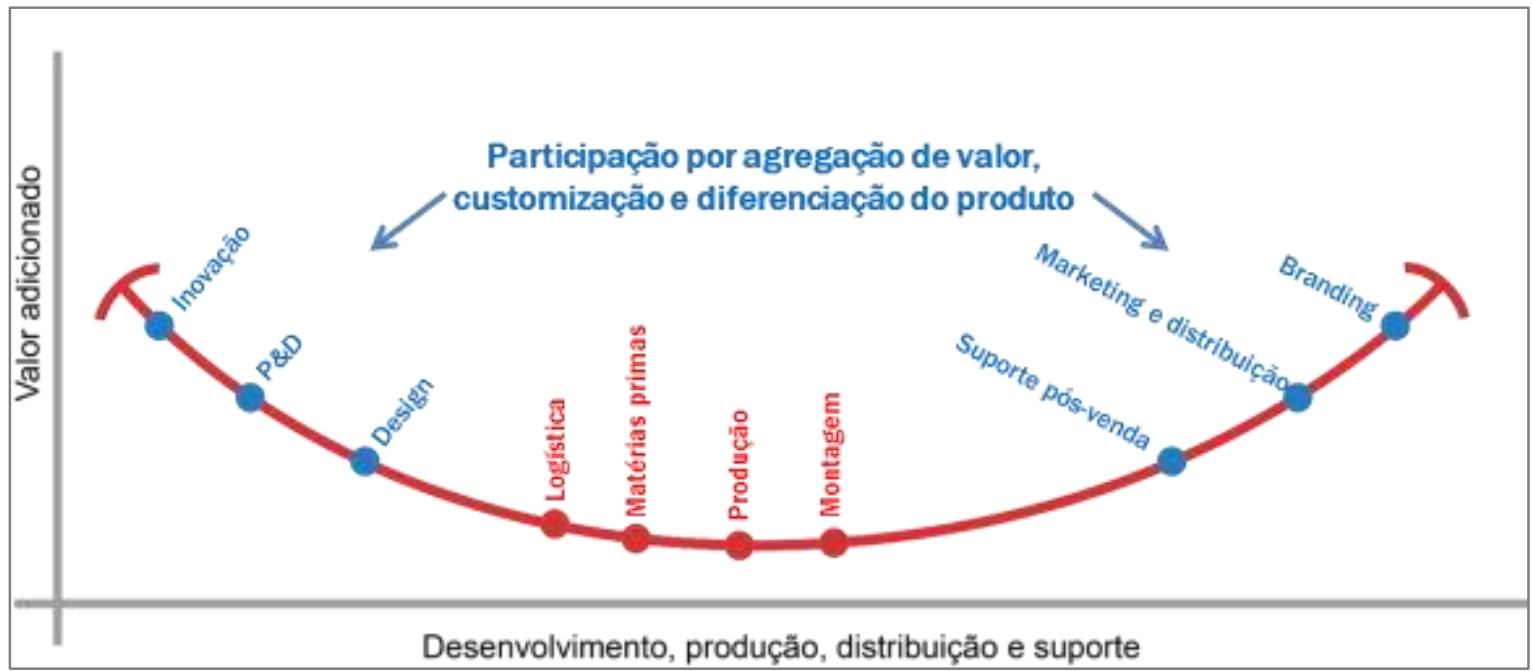

Fonte: Arbache (2014).

Figura 4 - Smiley face curve de países em processo de desenvolvimento

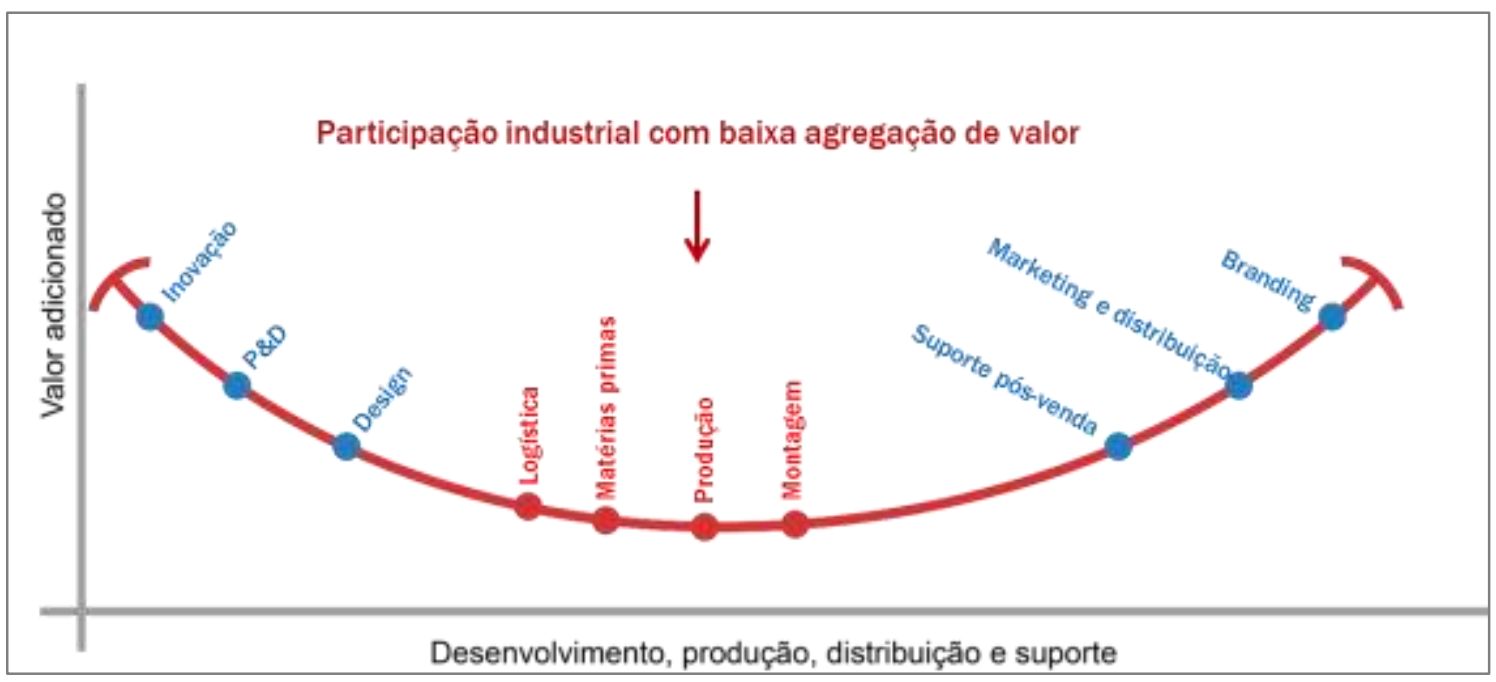

Fonte: Arbache (2014).

22 Acer - Empresa de origem taiwanesa que está entre as maiores fabricantes de computadores do planeta. 
Nota-se claramente que é nas extremidades que se concentram as atividades produtivas dos países mais desenvolvidos, local sede de empresas transnacionais, de empregos qualificados, do conhecimento, além é claro, da maior parte dos rendimentos. As atividades menos nobres da curva, situadas no centro, são frequentemente terceirizadas para empresas localizadas em países em processo de desenvolvimento, que também competem entre si para a realização de etapas e processos produtivos caracterizados pela pouca diferenciação.

\subsection{Megatendências que impactam na questão da divergência}

A divisão internacional do trabalho e a divergência de renda entre nações ricas e pobres tende a se acirrar nas próximas décadas, como resultado da busca pela competitividade entre os Estados. A intensidade dos avanços tecnológicos, 0 encurtamento do ciclo de vida dos produtos, a sinergia entre o setor de serviços e 0 industrial e a customização produtiva são apenas algumas das dinâmicas econômicas que afetam o desenvolvimento dos países. Entretanto, é necessário desbravar as outras tendências econômicas e sociais, no sentido de tentar prever possíveis diretrizes e orientar a construção de novos modelos ao desenvolvimento.

Partindo desse princípio, a presente sessão busca apresentar quais são as principais megatendências na visão de organizações internacionais ${ }^{23}$, algumas das quais já afetam o setor industrial e outras que poderão impactar o desenvolvimento dos Estados, principalmente daqueles em processo de desenvolvimento. Sob uma visão estratégica, conhecer as novas dinâmicas - econômicas, sociais, políticas e, até mesmo, ambientais - pode ser o diferencial daqueles Estados que desejam aprimorar seu desenvolvimento, no contexto da competitividade e das poucas oportunidades à minimização das desigualdades e da divergência de renda per capita entre o mundo desenvolvido e aquele em processo de desenvolvimento.

23 ONUDI, Conferência das Nações Unidas sobre Comércio e Desenvolvimento (UNCTAD), OCDE, Banco Mundial e Banco Interamericano de Desenvolvimento (BID). 


\subsubsection{Globalização}

$\mathrm{Na}$ economia global da atualidade, empresas não operam isoladamente e nem atuam em um único país. As interconexões de empresas, a sofisticação industrial e o espraiamento produtivo pelo mundo enunciam que os países em busca de seu desenvolvimento com o estímulo do setor produtivo devem saber operar neste emaranhado econômico e social que se intensificará ainda mais nas próximas décadas.

Produtos são fabricados em etapas cada vez mais fragmentadas e os processos produtivos subdivididos em diferentes territórios no globo. Matérias primas são extraídas em um país, insumos intermediários manufaturados em outros, enquanto a montagem final em uma terceira ou quarta localidade, a depender do número de etapas produtivas. O produto final, por sua vez, é exportado para tantos outros países e regiões, que é possível se perder na análise logística de um único bem ou produto manufaturado. O que ilustra a difusão das cadeias de valor e processamento fabril no contexto industrial de hoje.

É comum, por exemplo, que os funcionários de uma empresa nunca tenham visto o produto final que chega ao consumidor, afinal o mundo virtual, as facilidades de comunicação e os processos logísticos avançados fragmentaram a estrutura do setor industrial de cada país para todo o mundo. Em outra medida, foram as etapas intermediárias da produção, ainda distantes de seu consumidor final, que passaram a representar a maior parte das trocas comerciais da atualidade, reorientando a dinâmica produtiva global antes orientada aos produtos finais ${ }^{24}$.

Ainda assim, ao executar tal fragmentação produtiva, os países buscam preservar em seus territórios as etapas de maior valor agregado, como P\&D, design e inovação. Desse modo, os países em processo de desenvolvimento não detêm o poder de decisão sobre o processo produtivo, que está concentrado nas sedes das grandes empresas. Cabe aos países não desenvolvidos, portanto, estruturar agendas de estímulo ao conteúdo local, como a atração de centros de P\&D aos seus países.

A China, por exemplo, aplicou, nas últimas décadas, políticas industriais de estímulo à atração ao seu território de etapas industriais de alto valor agregado, com

\footnotetext{
${ }^{24}$ Miroudot, Lanz \& Ragoussis (2009).
} 
o objetivo de ampliar localmente a qualidade dos empregos e o desenvolvimento de ciência e tecnologia. De fato, estimativas indicam que cerca de $90 \%$ do P\&D de produtos eletrônicos são hoje produzidos na Ásia e que os investimentos em P\&D de empresas norte-americanas cresceram na ordem de 2,65 vezes mais no exterior do que no próprio território dos Estados Unidos ${ }^{25}$. As nações desenvolvidas sabem que não podem se distanciar da fronteira do conhecimento, pois é exatamente o que os mantêm na dianteira.

Nesse sentido, aqueles países em processo de desenvolvimento podem e devem adotar estratégias proativas à aquisição e ao desenvolvimento de ciência, tecnologia e inovação, com vistas ao estímulo de capacidades competitivas propícias ao desenvolvimento nacional e local. Entretanto, as iniciativas precisam estar estruturadas sob um arcabouço estratégico de políticas industriais sólidas de longo prazo, em que cada país esteja apto a ampliar sua participação nas cadeias globais de valor de forma qualificada e promover as capacidades domésticas imprescindíveis ao seu desenvolvimento sustentável.

\subsubsection{Sustentabilidade}

A sustentabilidade no setor industrial extrapola os limites do ambiente fabril (tabela 2), pois abarca outras atividades à jusante (anterior) e à montante (posterior) ao setor, como a utilização e consumo de energia, a operação dos fluxos logísticos de produção e distribuição e a administração de resíduos, de insumos e do próprio produto ao longo do seu ciclo de vida, em especial após seu uso.

Nesse sentido, a redução dos impactos ambientais causados pelo setor requer a adoção de medidas por parte de países desenvolvidos e em processo de desenvolvimento, que influenciarão as estratégias de desenvolvimento industrial nas décadas futuras. A minimização do uso de energia nos processos produtivos, a redução da emissão de poluentes, o desenvolvimento de materiais mais leves, mais resistentes e melhor recicláveis criam novas oportunidades ao mundo em desenvolvimento, mas ampliam os desafios tecnológicos.

25 ITIF (2011) apud UNIDO (2013a). 
Percebe-se claramente que a dinâmica industrial passa por processo de transformação que cria novos mercados consumidores ambientalmente engajados e dispostos a reverter o caminho de degradação dos últimos séculos. Sob a ótica social, as manufaturas podem ampliar o desenvolvimento em consonância com o meio ambiente, mas se estiverem engajadas em uma estrutura institucional e política que venha a estimular a geração de empregos bem pagos, qualificados e seguros aos seus cidadãos, com a redução ao uso de recursos escassos na natureza, o melhor dimensionamento da energia e da água empregada e a minimização de desperdícios.

O que está sendo, entretanto, amplamente questionado e debatido nos foros internacionais dedicados ao tema é se as responsabilidades pela degradação ambiental devem ser igualmente compartilhadas entre o mundo desenvolvido e aquele em processo de desenvolvimento. Longe de um consenso, o importante é que os países em processo de desenvolvimento estruturem políticas ao adicionar estratégias em linha com esta tendência.

\section{Tabela 2 - Poluentes resultantes de processos de manufatura}

\begin{tabular}{|c|c|}
\hline Poluentes & Consequências \\
\hline $\begin{array}{l}\text { Gases causadores do efeito estufa } \\
\text { provenientes do uso direto ou indireto de } \\
\text { energia, gases de aterros sanitários }\end{array}$ & Mudança do clima \\
\hline $\begin{array}{l}\text { Emissão de toxinas, substâncias } \\
\text { cancerígenas, incluindo o uso de metais } \\
\text { pesados, ácidos solventes ou queima de } \\
\text { carvão }\end{array}$ & Danos ao organismo humano \\
\hline $\begin{array}{l}\text { Uso e descarte da água, em sistemas de } \\
\text { arrefecimento e limpeza }\end{array}$ & Disponibilidade e qualidade da água \\
\hline $\begin{array}{l}\text { Uso de combustíveis fósseis para } \\
\text { aquecimento e geração de energia }\end{array}$ & $\begin{array}{c}\text { Esgotamento de recursos combustíveis } \\
\text { fósseis }\end{array}$ \\
\hline $\begin{array}{l}\text { Uso do solo, da água, deposição ácida e } \\
\text { poluição térmica }\end{array}$ & Perda da biodiversidade \\
\hline $\begin{array}{c}\text { Emissões de CFCs, HCFCs e óxidos } \\
\text { nitrosos, uso de flúor composto, para } \\
\text { sistemas de resfriamento e métodos de } \\
\text { limpeza }\end{array}$ & Destruição da camada de ozônio \\
\hline $\begin{array}{l}\text { Uso de recursos naturais e geração de } \\
\text { resíduos }\end{array}$ & Esgotamento dos recursos naturais \\
\hline $\begin{array}{l}\text { Emissões de enxofre provenientes do uso de } \\
\text { combustíveis fósseis e processos de } \\
\text { fundição }\end{array}$ & Disposição de ácido \\
\hline
\end{tabular}




\subsubsection{Demografia}

As dinâmicas demográficas da atualidade influenciarão o setor industrial, em termos de magnitude, composição e qualificação educacional dos recursos humanos empregados. Nos países desenvolvidos, por exemplo, o envelhecimento populacional e a carência de mão de obra jovem qualificada na magnitude da reposição necessária podem comprometer a produção industrial.

Desde 2012, a população economicamente ativa na Europa decresce, associado ao fato de que a geração "baby boomer" está em processo de aposentadoria $^{26}$. A baixa composição de jovens no continente não conseguirá repor a grande quantidade de aposentadorias nos próximos anos, o que pode comprometer processos de reposição de funcionários, contratação, treinamento e incremento produtivo nos países europeus.

Em adição ao avanço da idade populacional por que passa diversos países desenvolvidos e que afeta as carências de recursos humanos no setor industrial, estão as concessões de benefícios sociais e de saúde a população com idade avançada. A alta taxa de dependência, representada pelo alto número de pensionistas, aposentados e dependentes de sistemas de saúde e baixo número de trabalhadores economicamente ativos, poderá elevar os impostos sobre a pequena parcela populacional ativa no continente.

\subsubsection{Cadeias Globais de Valor}

O desenvolvimento do setor industrial de países em processo de desenvolvimento requer mais do que o estímulo às exportações e à produção de bens de alto valor agregado. Afinal, os sistemas produtivos do mundo contemporâneo passam por um processo de adaptação que necessita de nova dinâmica baseada na inovação e na agregação constante de valor, explorando cadeias globais.

Atualmente, países desenvolvidos buscam modernizar o setor industrial ao estimular atividades de alta densidade tecnológica, por vezes atraindo processos produtivos que antes tinham transferido para países de mão de obra mais barata.

\footnotetext{
26 DG Enterprise and Industry (2010) apud UNIDO (2013).
} 
Cabe destacar que os custos de produção em países desenvolvidos são minimizados quando se considera os fatores adequados de infraestrutura, logística, serviços e produtividade, comparativamente mais fluidos nesses países do que em países em desenvolvimento, compensando os custos de mão de obra mais elevados.

No contexto produtivo atual, países do sudeste asiático e alguns africanos desenvolvem políticas de atração de manufaturas. A China, por exemplo, busca controlar custos trabalhistas, que estão em ascensão, na busca pela modernização tecnológica do setor industrial com a agregação de valor. Os países latinoamericanos, por sua vez, têm dificuldades para perceber as novas dinâmicas e estruturar as políticas necessárias à sua melhor inserção neste cenário de mudanças nos fluxos industriais contemporâneos.

O mundo cada vez mais plano ${ }^{27}$ requer dos países uma nova estrutura produtiva que melhor os insira nas cadeias globais de valor (CGV), fator que beneficia àqueles mais inovadores. Inserir-se nessas cadeias exige dos países uma adaptabilidade para estruturar a difusão da produção de um determinado bem ou serviço no mundo, com o objetivo de aprimorar a competitividade, por meio da redução de custos, aumento da eficiência e da qualidade produtiva e da proximidade a novos mercados, a centros de conhecimento e a ecossistemas mais propícios à inovação.

Para os países em processo de desenvolvimento, inserir-se em CGV de forma qualificada, desenvolvendo produtos de alto valor agregado, estimula:

(1) a especialização produtiva, conforme suas vantagens comparativas e dotação de insumos;

(2) o acesso a novos mercados e a integração na economia global, conforme sua abertura econômica e o perfil das exportações, reforçando as capacidades do país a choques externos, instabilidades políticas, econômicas e financeiras;

(3) a integração na economia global e

(4) o acesso a capital humano e institucional internacional, como melhores infraestruturas e sistemas logísticos, ambientes políticos mais propícios ao

27 "O Mundo é Plano", obra de Thomas Friedman, analisa detidamente o atual processo de globalização, de redução do tempo e espaço, de interconexões mais acirradas entre países, de cadeias globais de valor, de produções descentralizadas com impactos na competição global entre os países por mercados e desenvolvimento econômico e social. 
desenvolvimento industrial, força de trabalho qualificada e proximidade a tecnologias mais sofisticadas.

Nesse contexto, os países que desejam aprimorar sua inserção em CGV devem reforçar a institucionalização de facilidades comerciais, como reformas alfandegárias, investimentos logísticos e transparência nas operações produtivas. Entretanto, essas medidas de maior liberalização comercial adensam os debates, quando se tornam desfavoráveis aos setores industriais menos competitivos.

Sob outra ótica, a inserção dos países em processo de desenvolvimento nas CGV deve ocorrer de forma qualificada, para que não venham a atrair exclusivamente atividades menos nobres, de menor agregação de valor, como produção e montagem. Via de regra, é o que ocorre nas últimas décadas, resultando na competição dos emergentes pela atração de investimentos, em um nível inferior à fronteira tecnológica, de inovação, design, pesquisa e desenvolvimento. Nesse estágio, os países que deveriam estar em fase de estruturação de seu desenvolvimento acabam por competir entre si na atração de investimentos, ofertando a baixos custos as condições de trabalho de seus cidadãos, os custos de produção e demais subsídios necessários ao desenvolvimento qualificado.

A posição em que os países atuam nas CGV depende, sobretudo, da intensidade de conhecimento que empregam em seu sistema produtivo, tendo em vista que produtos intensivos em conhecimento serão, sem sombra de dúvidas, os mais competitivos no cenário futuro. A inserção dos países em CGV em patamares próximos da fronteira tecnológica e do conhecimento permite a agregação de riqueza, bem-estar social, empregabilidade e desenvolvimento industrial qualificado, muito próximo à fronteira da inovação. Como resultado, os países que mais se desenvolvem na atualidade são aqueles melhor adaptados e inseridos nas CGV, o que acaba sendo também o território de polos de desenvolvimento produtivo e de conhecimento.

Desse modo, a estratégia para a inserção de um país nas CGV de forma qualificada deve perpassar por políticas de estímulo ao desenvolvimento industrial e de atração de investimentos externos, incentivos fiscais, subvenção à inovação e construção de vantagens comparativas. A busca pelo conhecimento, inclusive de forma colaborativa com outros agentes, tenderá a criar um processo de "clusterização" do conhecimento, em que apenas os países membros e atuantes nessa fronteira da inovação é que serão os mais beneficiados para seu desenvolvimento. 


\subsubsection{Serviços, conhecimento e geração de riquezas}

A questão da divergência de renda entre países desenvolvidos e aqueles em processo de desenvolvimento se intensifica na medida da indissociável relação econômica e comercial entre os setores industrial e o de serviços. Segundo Arbache (2014), os serviços representam $75 \%$ das economias da Organização para a Cooperação e Desenvolvimento Econômico (OCDE), passando dos 80\% nos Estados Unidos e dos 54\% nas economias de renda média. O setor industrial e o de serviços adensarão cada vez mais esta simbiose, processo conhecido como "servicização" da economia.

Os resultados mais visíveis dessa simbiose para o setor industrial estão relacionados às mudanças na natureza dos bens manufaturados, quando bens $e$ serviços associados passam a formar um terceiro produto, manufaturado, mas baseado no conhecimento agregado com serviços. Como visto, os serviços são uma parcela em ascensão no valor adicionado de bens manufaturados, relação que passa dos $60 \%$ em países industrializados.

Figura 5 - Relação entre serviços e valor adicionado industrial (\%) 2005 ou ano mais recente

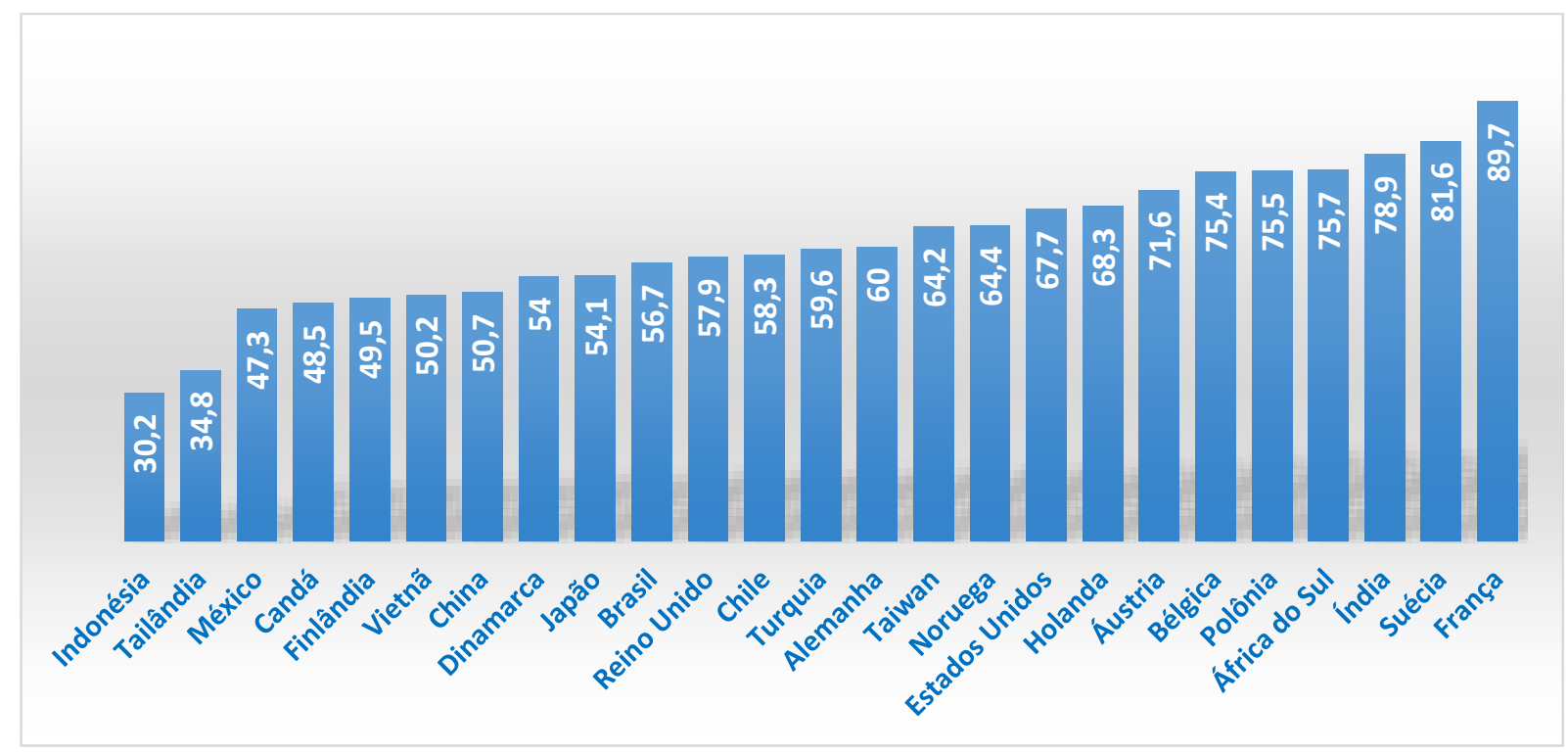

Fonte: OCDE Input-Output Dataset apud Arbache (2014). 


\section{Figura 6 - Participação dos insumos de serviços no produto industrial bruto - PIB (\%) - 2005 ou ano mais recente}

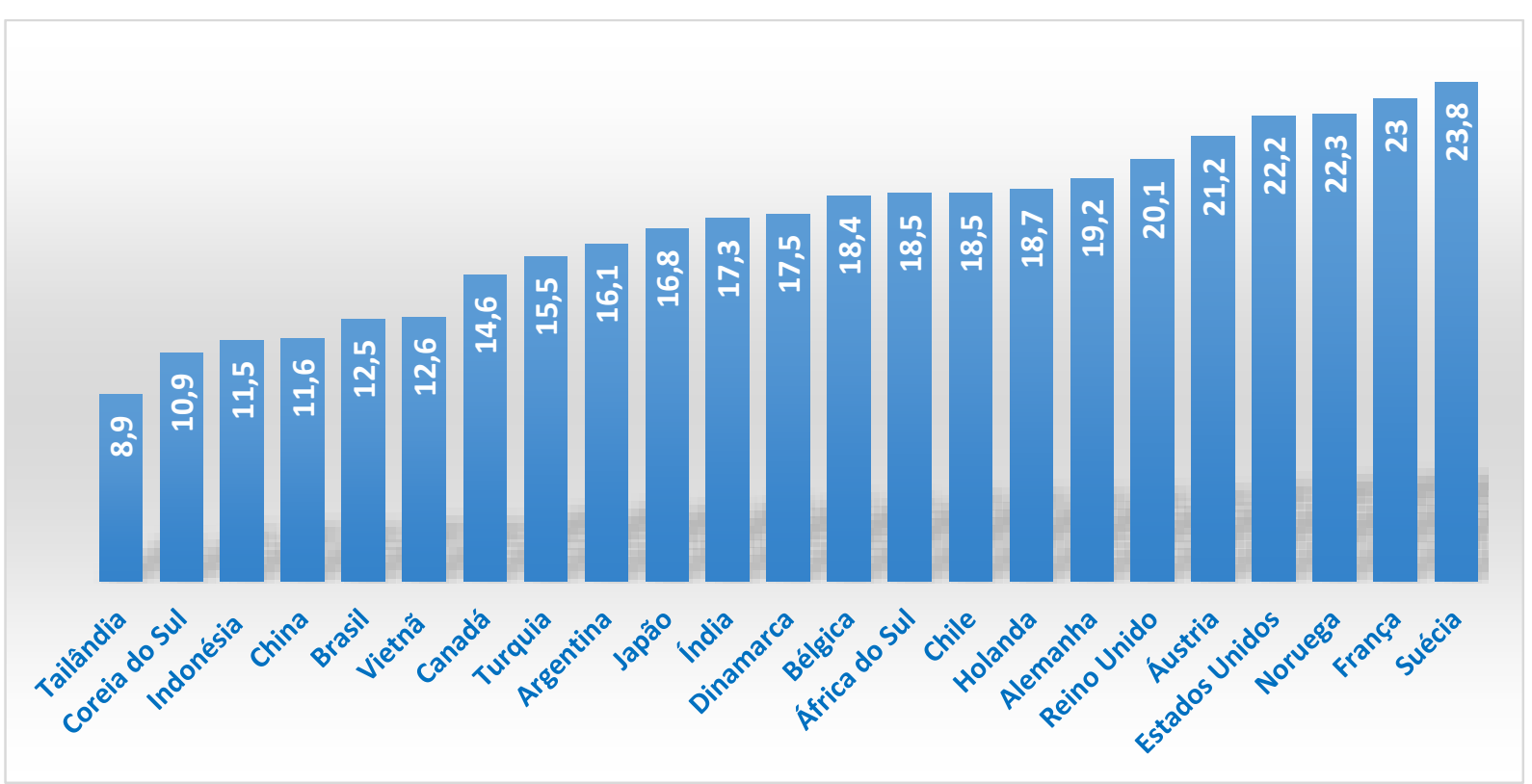

Fonte: OCDE Input-Output Dataset apud Arbache (2014).

O setor de serviços impacta no setor industrial em dois momentos da etapa produtiva (como representado nas figuras 03 e 04). O primeiro momento refere-se àqueles serviços que agregam valor na etapa de customização de produtos, o que eleva o preço de mercado do bem e a remuneração do capital investido, tratando-se do desenvolvimento de $P \& D$, design e inovação na forma de softwares, consultorias e serviços técnicos especializados, por exemplo. O segundo momento refere-se às funções que impactam nos custos de produção e comercialização, como sistemas logísticos, branding ${ }^{28}$, marketing e suporte pós-venda.

Sob a análise da questão da divergência de renda, as novas dinâmicas econômicas e sociais globais tendem a concentrar os serviços de agregação de valor em países desenvolvidos, enquanto que as atividades menos nobres da cadeia produtiva, como produção e montagem, são comumente terceirizadas aos países em processo de desenvolvimento. É razoável concluir que, apesar de os países em desenvolvimento estarem participando cada vez mais da economia mundial, ocorrerá

${ }^{28}$ Etapa de gestão da marca de um produto ou serviço, como, por exemplo, o desenvolvimento de logotipo, slogan e identidade visual. 
o adensamento das desigualdades, internas e externas, naqueles países que negligenciarem a simbiose indústria-serviços.

Agregar valor produtivo, romper constrangimentos comerciais e ampliar o crescimento econômico e social de forma sustentada devem fazer parte da estratégia daqueles que não desejam se tornar reféns de uma economia mundial, que concede poucas oportunidades ao mundo em desenvolvimento. O perfil de consumo de serviços pode também ser uma das estratégias, pois está diretamente associado ao perfil industrial do país. Enquanto um setor industrial de maior intensidade tecnológica demanda serviços mais sofisticados - royalties, assistência técnica, marketing -, o setor industrial commoditizado demanda também serviços padronizados. A baixa intensidade tecnológica nos serviços utilizados pelo setor industrial, estanca o desenvolvimento de um país em um patamar econômico defasado com as suas necessidades de crescimento. Isso decorre do fato de que tanto o setor industrial demanda serviços, como o setor de serviços demanda bens manufaturados, em um ciclo - virtuoso ou vicioso - que favorece ou compromete o desenvolvimento produtivo.

A importância do setor de serviços extrapola a mera complementariedade com o setor industrial, quando demonstra ser a principal fonte de geração de empregos no mundo e o destino de parcela cada vez maior dos Investimentos Estrangeiros Diretos $(\text { IED })^{29}$. Evidências empíricas demonstram também que o setor de serviços está intimamente associado aos preços das exportações. ${ }^{30}$

Segundo Arbache (2015), o comércio de serviços é uma das mudanças mais relevantes que se vislumbra na atualidade:

Hoje, o comércio de serviços, tanto os embutidos nos bens industriais, como os não embutidos, já corresponde a $50 \%$ do total do comércio mundial. Mas, no futuro próximo, os serviços serão largamente predominantes em razão da sua crescente contribuição

\footnotetext{
${ }^{29}$ Segundo Wolffenbüttel (2006), Investimento Estrangeiro Direto (IED) é todo o aporte de dinheiro vindo do exterior que é aplicado na estrutura produtiva doméstica de um país, na forma de participação acionária em empresas existentes ou na criação de novas empresas.

30 "Serviços e Competitividade Industrial no Brasil", estudo elaborado pela Confederação Nacional da Indústria (CNI) em 2014.
} 
para a geração de valor dos bens industriais e até agrícolas. (ARBACHE, 2015, p.1)

Percebe-se que os principais países produtores de serviços no mundo estão mobilizados para a defesa de seus interesses nos principais foros de comércio internacional, inclusive em organizações internacionais, como a Organização Mundial do Comércio (OMC), quando buscam a liberalização ampla dos serviços, inclusive aqueles embutidos em bens manufaturados. Com pouco sucesso nesses foros, nações desenvolvidas têm negociado acordos comerciais à margem de foros multilaterais, como a OMC. As recentes negociações de acordos como, por exemplo, o TTP ${ }^{31}$ e TTIP 32 , ilustram essa tentativa de destravamento da agenda, na busca por crescimento econômico e desenvolvimento.

\subsubsection{Fluxos internacionais de comércio}

O comércio internacional passa por um ponto de inflexão, com a proliferação de acordos preferenciais de comércio (APCs). A OMC, organização internacional responsável pelos principais acordos multilaterais de comércio, mesmo fortalecida com o processo realizado recentemente em Bali33, tem seu papel frequentemente questionado perante a multiplicação desses acordos, ampliando os desafios ao comércio, ao setor industrial e, principalmente, ao mundo em desenvolvimento.

A situação se deteriora aos países em processo de desenvolvimento, quando as principais economias do mundo buscam novas opções em termos de comércio. $A$ Parceria Transpacífica (TPP) e a Parceria Transatlântica de Comércio e Investimentos (TTIP), que envolvem algumas das maiores economias mundiais, como Estados Unidos e países europeus, trarão impactos relevantes ao setor industrial e devem, portanto, ser consideradas pelos países em processo de desenvolvimento.

31 Parceria Transpacífica (TTP) - acordo comercial negociado por países como Estados Unidos, Austrália, Brunei, Canadá, Singapura, Chile, Japão, Malásia, México, Nova Zelândia, Peru e Vietnã. O acordo ainda não se encontra em vigor, pois depende da ratificação dos Estados.

32 Parceria Transatlântica de Comércio e Investimentos (TTIP) - acordo comercial sob negociação entre os Estados Unidos e a União Europeia.

${ }^{33}$ Processo de Bali - acordo histórico celebrado em dezembro de 2013 pelos 159 estados membros da OMC, o primeiro após a criação da instituição em 1995. Trata-se de ambicioso projeto em prol da liberalização do comércio mundial, iniciado em 2001 em Doha, no Qatar. A OMC quantificou que o acordo de Bali representaria aproximadamente a injeção de 1 trilhão de dólares na economia mundial em termos de facilitação comercial. 
O regime de comércio vive, portanto, profundo impasse na atualidade, quando o papel antes exercido pela OMC é questionado e enfrenta processo de possível substituição por regras bilaterais e regionais, negociadas no âmbito de APCs. O comércio internacional convive, de forma por vezes conflitante, com a multiplicação de três tipos diferentes de regras: (1) regras compatíveis com as da OMC ("OMC in"), como desgravação tarifária e defesa comercial; (2) regras que avançam nos temas já cobertos pela OMC ("OMC plus"), como serviços, salvaguardas e propriedade intelectual; e (3) regras que regulamentam temas não cobertos pela OMC ("OMC extra'), como investimento, concorrência, meio ambiente e padrões trabalhistas. Essa variedade de novos acordos e regras, por meio da celebração de APCs, muitas vezes sem a supervisão e o consenso dos membros da $\mathrm{OMC}$, fragmenta o sistema regulatório e cria significativos entraves às negociações multilaterais de comércio.

O momento atual, portanto, impacta nas políticas nacionais de desenvolvimento em diversos setores econômico-produtivos. Os países em processo de desenvolvimento, mesmo com o sucesso do Processo de Bali no âmbito da OMC, precisam repensar suas estratégias de inserção internacional, dando prioridade a outras negociações e dinâmicas comerciais, que trarão impactos positivos ao setor industrial.

Como os "mega-acordos" (TTP e TTIP) ainda estão em fase de negociação ou implementação, ainda é difícil prognosticar seus impactos para o mundo em desenvolvimento. Mas é possível desde já perceber que a tendência de fragmentação da estrutura regulatória e o paulatino abandono dos princípios multilaterais de comércio que regulam as relações econômicas. É evidente, portanto, que aqueles países que estiverem à margem das negociações, dos debates e do conhecimento gerado pelas novas redes e fluxos internacionais de comércio se verão em termos desfavoráveis no acesso à mercados, realização de investimentos e desenvolvimento de novas tecnologias.

O caminho a ser adotado, assim, deve contemplar uma estratégia mais ampla de inserção internacional, tanto em termos comerciais, como econômicos e produtivos, que estejam em linha com a sua política externa. Percebe-se, sobretudo, que a celebração desses "mega-acordos" coloca os países em processo de desenvolvimento em posição sensível no cenário internacional, em especial no desenvolvimento por meio do estímulo industrial, o que torna imperativo e urgente a 
construção de políticas comerciais sólidas nesses países. Além disso, o poder de barganha comercial junto aos países desenvolvidos está ameaçado, frente ao caráter estratégico que os novos acordos terão em relação aos regimes de comércio internacional.

\subsubsection{Urbanização}

Na estrutura econômica de um típico país em desenvolvimento, a agricultura é a atividade econômica predominante no valor adicionado e no emprego, ao passo que o setor industrial e o de serviços ocupam menores parcelas do PIB. À medida que o processo natural de urbanização ocorre e a renda per capita aumenta, a agricultura perde primazia na economia. A expansão do PIB, da renda per capita e do processo de urbanização tendem a demandar produtos manufaturados e serviços com a maior agregação de valor, o que é acompanhado de outras demandas paralelas como educação, saúde, previdência, lazer, o que amplia a cesta de consumo das famílias e, por vezes, o desenvolvimento econômico e social.

De acordo com as Nações Unidas, mais da metade da população mundial vive em cidades, índice que chegará a $72 \%$ por volta do ano de 2050. A figura abaixo estratifica as mudanças por que passarão os continentes africano e asiático nas próximas décadas, que testemunharão, segundo prognósticos, o maior processo de urbanização do mundo.

\section{Figura 7 - Distribuição da população urbana mundial (\%)}

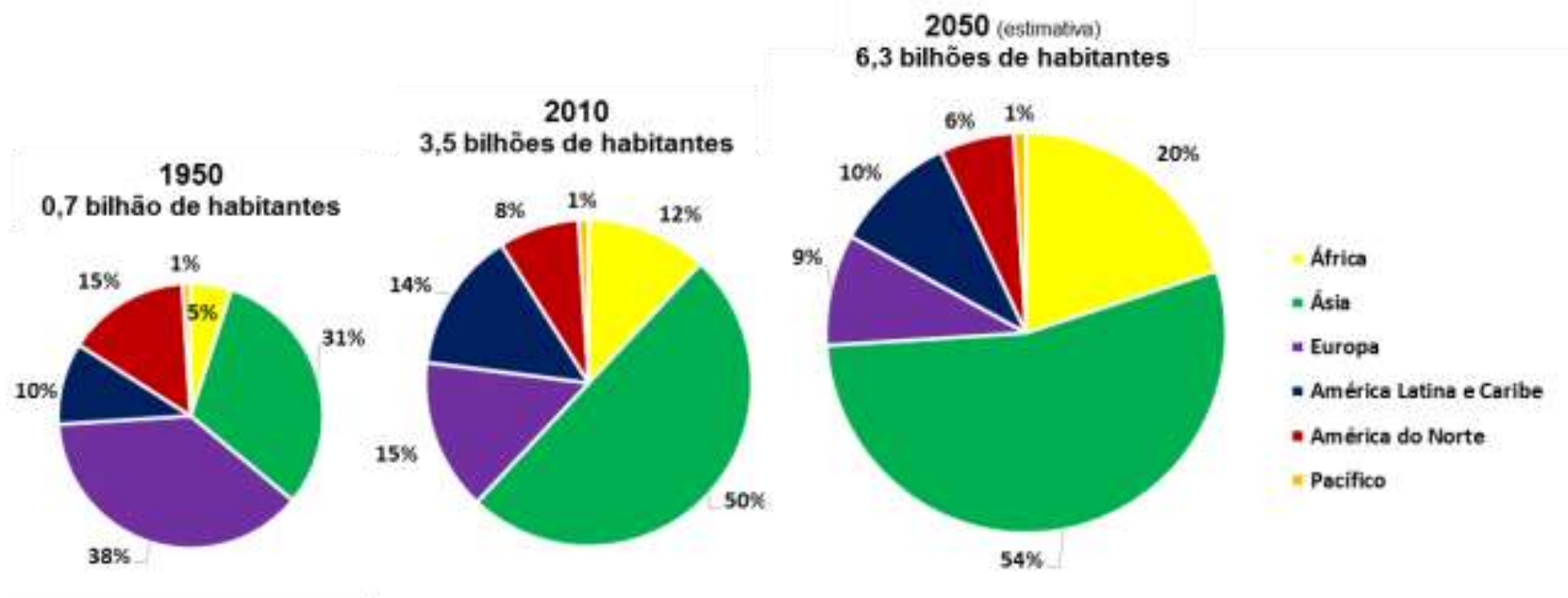

Fonte: United Nations (2011) apud UNIDO (2013a). 
O processo de urbanização trará consequências avassaladoras aos países, tanto desenvolvidos como em processo de desenvolvimento, com reflexos diretos no setor industrial. Carências habitacionais, congestionamentos, degradação ambiental, insegurança e desemprego são apenas algumas das consequências advindas desse processo acelerado de urbanização que enfrentam e enfrentarão diversos países em transição.

Para sanar algumas dessas consequências, os países, em especial, em processo de desenvolvimento, menos preparados para esta dinâmica ocupacional, deverão reforçar soluções de mobilidade urbana, ampliando sistemas de transporte e logísticos; ampliar o planejamento urbano, para construção de soluções habitacionais e projetar cidades que sejam economicamente viáveis, ambientalmente sustentáveis e funcionalmente inteligentes.

\subsubsection{Ameaças a estabilidade global}

Instabilidades geopolíticas trazem sérias consequências para países em busca de desenvolvimento, e políticas de contenção devem estar no radar daqueles que desejam estruturar suas políticas industriais, para que sejam sólidas e sustentáveis no longo prazo. Como ameaças à estabilidade global, pode-se citar desastres naturais, conflitos armados, terrorismo e ameaças à segurança estatal.

Desastres naturais, como o recente terremoto japonês de 2011 e o vazamento nuclear na usina de Fukushima, comprovam como instabilidades ambientais podem trazer sérias consequências aos fluxos produtivos, logísticos e econômicos do mundo contemporâneo. Um desastre natural de grandes proporções pode provocar drásticas carências de mantimentos básicos, o que resulta em elevação de preços e, até mesmo, instabilidades políticas. A fragmentação das manufaturas pelo mundo e a interconectividade das economias comprovam que um desastre natural em localidades estratégicas pode trazer consequências sérias ao setor produtivo na economia globalizada.

Da mesma forma que os desastres naturais, os conflitos armados tendem a interromper fluxos produtivos nesta cadeia global de valor cada vez mais fragmentada, mas interconectada. Como exemplos dos impactos dos conflitos armados nas cadeias 
produtivas globais, cita-se a conflagração na Líbia, no ano de 2011, que fez com que 2/3 do petróleo produzido pelo país não chegasse ao seu destino final; ou os piratas espalhados pelo mundo, que elevam os custos da economia internacional em algo entre U\$7 bilhões e U\$12 bilhões por ano ${ }^{34}$.

Longe de exaurir todas as possíveis influências de conflitos internacionais nos fluxos produtivos, estão o terrorismo e as ameaças à segurança estatal. Essas externalidades, além de fomentar a indústria bélica que não contribui para o desenvolvimento humano e social no âmbito mundial, estimula o adensamento de novas regulamentações restritivas em prol da manutenção da segurança, que dificultam e, por vezes, impedem fluxos produtivos internacionais.

\subsubsection{Ciclo de vida dos produtos}

Outra megatendência que deve constar no escopo de análises dos países em busca de desenvolvimento é o ciclo de vida cada vez mais reduzido e dinâmico dos produtos. As inovações se sobrepõem, as tecnologias ficam defasadas com grande rapidez e novas demandas surgem com frequência, alterando mercados, indústrias, empresas e exigindo novas políticas de fomento ao setor industrial. Como exemplo, Dediu (2012) cita o caso do telefone, que levou aproximadamente 70 anos para atingir uma penetração de $80 \%$ no mercado consumidor norte-americano, enquanto os smart phones de hoje demorarão apenas 15 anos para atingir o mesmo nível de penetração entre os consumidores.

Essa minimização do ciclo de vida dos produtos provoca nos consumidores uma frequente demanda por novos produtos e serviços customizados, o que culmina no desenvolvimento de processos produtivos dedicados às novas realidades mercadológicas. Nesse sentido, aqueles países que desejarem aprimorar seus níveis de desenvolvimento devem buscar acompanhar as novas dinâmicas produtivas da atualidade, principalmente as relacionadas à agregação de valor constante aos produtos manufaturados.

\footnotetext{
34 World Economic Forum (2012).
} 


\subsubsection{Síntese das megatendências}

É perceptível que ter um setor industrial sólido não é mais garantia de promoção do desenvolvimento no cenário futuro. Arbache (2015) destaca que a maioria dos países em processo de desenvolvimento não percebeu a realidade ímpar de que o importante não é mais ter uma indústria, mas qual indústria se deseja ter. Além disso, não identificaram estratégias de inserção nas CGV ou perceberam que o conhecimento associado à agregação de valor é uma das soluções existentes para seu desenvolvimento.

Aqueles países que almejam ampliar o seu nível de desenvolvimento devem, portanto, estar cientes de que um setor industrial bem estruturado e competitivo em termos globais é estratégia básica para enfrentar as megatendências da atualidade. Países desenvolvidos têm realizado pesados investimentos em P\&D, estimulam ciência e tecnologia e adensam suas políticas industriais para a manutenção do desenvolvimento. Cabe, portanto, aos países em processo de desenvolvimento perceber que novas dinâmicas globais estão em andamento, a fim de prospectar e analisar outras que ainda irão surgir, no intuito de minimizar a divergência de renda entre os países.

O capítulo buscou sintetizar as principais tendências que impactam o setor industrial dos países em processo de desenvolvimento, tendo como referência a realidade dos sistemas produtivos da atualidade, tanto de países desenvolvidos como em processo de desenvolvimento. Entre as megatendências analisadas estão o processo de globalização e a reindustrialização dos países desenvolvidos, os fatores ambientais e a sustentabilidade como objetivos motrizes do desenvolvimento industrial, os impactos demográficos na população economicamente ativa, os processos de urbanização, a relação sinergética entre os setores industrial e o de serviços, a inserção qualificada dos países nas cadeias globais de valor, os fluxos de comércio internacional, as ameaças a estabilidade global e a questão dos conflitos armados que interrompem fluxos produtivos e o ciclo de vida cada vez mais célere dos produtos.

A análise do espaço-indústria e as tendências econômicas globais, aqui denominadas como megatendências, e sua relação com o setor industrial são informações essenciais àqueles países em processo de desenvolvimento que buscam 
construir ou aprimorar as estratégias de fomento industrial. A partir desse referencial, analisa-se, no próximo capítulo, como os países desenvolvidos estão estruturando suas políticas industriais e como a ONUDI busca compor seus projetos de estímulo industrial. 


\section{COMPARATIVO ENTRE AS POLÍTICAS INDUSTRIAIS}

A crise econômica e financeira de 2008, desencadeada em países desenvolvidos, com efeitos em todo o mundo, reforçou a necessidade de se buscar novas formas de geração de emprego e renda. O fortalecimento do setor industrial tem sido uma das estratégias adotadas por diferentes países para o desenvolvimento político, econômico e social.

Conforme analisado no capítulo anterior, o setor industrial passa por fortes transformações, que afetam tanto países desenvolvidos como em processo de desenvolvimento. Esse fato reforça a necessidade de serem adotadas novas estratégias nacionais e ferramentas diversificadas para a manutenção da competitividade e do desenvolvimento, principalmente entre os países em processo de desenvolvimento.

O presente capítulo descreve em duas sessões (1) como países desenvolvidos selecionados, como Estados Unidos, Alemanha, Japão e Reino Unido ${ }^{35}$ estruturamse para aprimorar seu desenvolvimento no futuro, quais são seus focos de atuação e as estratégias que estão adotando e (2) como a ONUDI, agência da ONU responsável pela promoção do desenvolvimento industrial de países em processo de desenvolvimento, busca estruturar seus projetos de estímulo industrial, quais suas variáveis de trabalho e as estratégias empregadas.

Parte-se do pressuposto de que as políticas industriais possuem ou deveriam possuir como objetivo central no longo prazo o desenvolvimento político, econômico e social dos Estados.

\subsection{O rumo das políticas industriais}

Para identificar as diretrizes existentes nas políticas industriais dos países desenvolvidos selecionados, utiliza-se como base de análise a matriz elaborada por Sullivan et al. (2013). Na matriz, os autores esboçam as orientações das políticas

\footnotetext{
${ }^{35}$ As análises das políticas industriais dos países desenvolvidos selecionados foram obtidas a partir de consultas realizadas a documentos oficiais de cada um dos países e da recente publicação da Oxford Review of Economic Policy, Volume 29, Número 2, 2013, pp.432-462.
} 
industriais em dois eixos que contemplam os níveis de intervenção e os fatores de produção, conforme a figura 8 abaixo.

Figura 8 - Matriz das Políticas Industriais

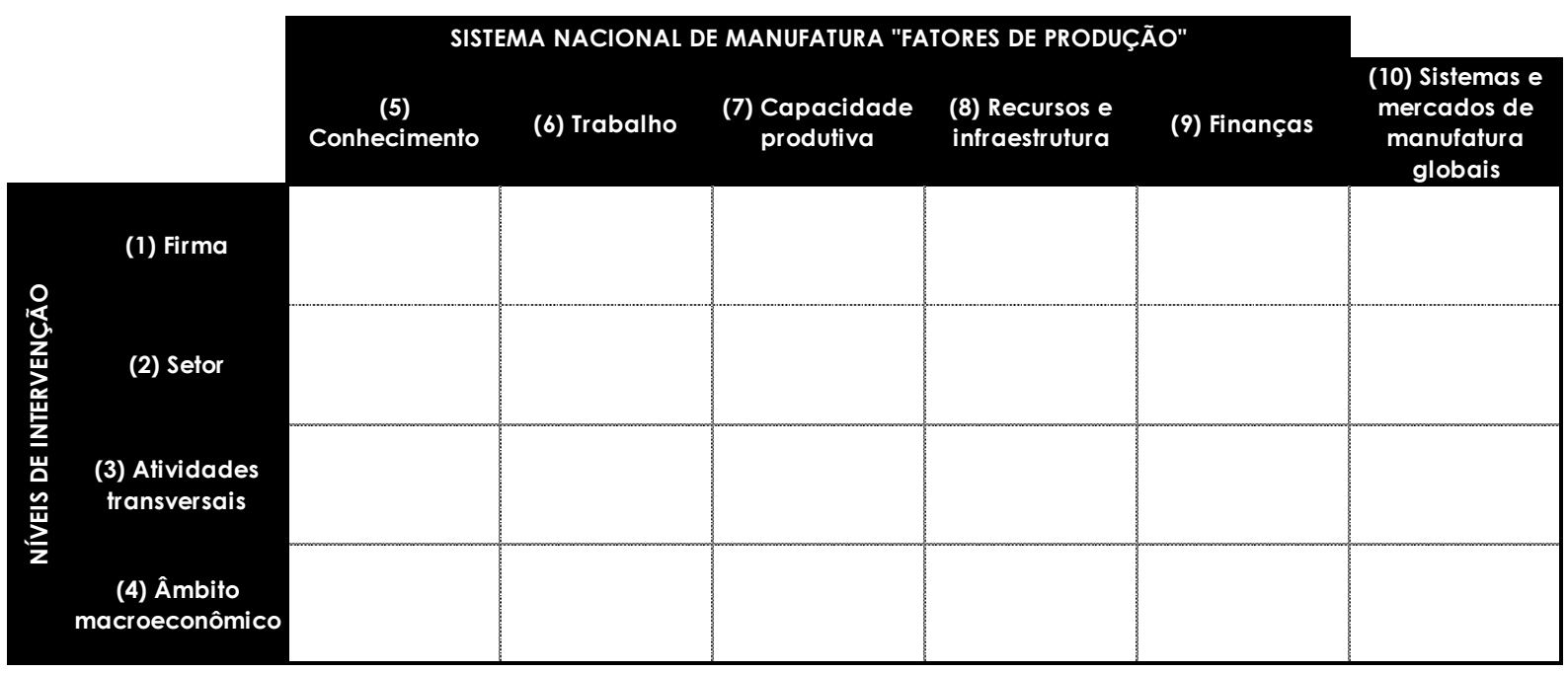

Fonte: Sullivan et al. (2013).

Os níveis de intervenção das políticas industriais são subdivididos em:

(1) nível da firma, quando a política busca fomentar empresas capazes de disputar e vencer em nível internacional a concorrência em setores estratégicos selecionados;

(2) nível do setor, quando a política privilegia uma indústria ou uma cadeia produtiva específica;

(3) atividades transversais, quando a política impacta em múltiplos setores ou cadeias produtivas e

(4) âmbito macroeconômico, quando a política industrial resulta da realização de políticas macroeconômicas, com impactos na renda, no emprego, nos preços, no consumo, na poupança e no investimento.

No outro eixo (“Sistema nacional de manufatura 'fatores de produção'”), os autores subdividem as políticas industriais entre os fatores de produção que buscam estimular, como:

(5) conhecimento, em particular com a realização de P\&D;

(6) trabalho, como educação e desenvolvimento de novas habilidades; 
(7) capacidade produtiva, com o incremento da capacidade fabril, como o desenvolvimento ou aquisição de máquinas e equipamentos ou estímulo ao investimento em novas plantas industriais;

(8) recursos e infraestrutura, como geração de energia e eficiência dos recursos empregados no setor industrial e

(9) finanças, como acesso à financiamento.

Por fim, mas não menos importante, Sullivan et al. (2013) completam a matriz com os "sistemas e mercados de manufatura globais", item 10 na figura acima, como a capacidade de uma política industrial fomentar a interação do país com mercados globais e redes de produção internacional.

Para ilustrar as orientações e as diretrizes existentes nas políticas industriais de países desenvolvidos, Sullivan et al. (2013) compila os rumos das políticas industriais de quatro países desenvolvidos - Reino Unido, Estados Unidos, Alemanha e Japão - e demonstra os pontos de convergência e divergência. Mais do que um indicativo das tendências nas políticas industriais que podem orientar países em processo de desenvolvimento, as análises a seguir buscam identificar as diretrizes essenciais que ainda não são consideradas por governos ou agências internacionais de estímulo industrial, como a ONUDI.

\subsubsection{Políticas industriais do Reino Unido}

Entre os países considerados neste estudo, o Reino Unido é o que apresenta as políticas industriais mais dinâmicas com relação à transformação estrutural em favor de serviços intensivos em conhecimento, baseados no mercado financeiro e no setor de telecomunicações. Como resultado, a participação das manufaturas na composição do PIB do país declinou nas últimas décadas, atingindo patamares próximos de $9 \%$ em $2014^{36}$.

Apesar do declínio, diversos setores no país ainda são fortes, como a indústria aeroespacial, atrás apenas dos Estados Unidos, e a automotiva, que registra acréscimos de produtividade e investimentos constantes em pesquisa e desenvolvimento. Automóveis, máquinas e equipamentos e produtos elétricos estão

\footnotetext{
${ }^{36}$ Acessível em: http://data.worldbank.org/indicator/NV.IND.MANF.ZS/countries/GB?display=graph.
} 
entre os principais itens exportados pelo país, contabilizando cerca de $27 \%$ das suas exportações ${ }^{37}$. Empresas químicas e farmacêuticas inglesas estão entre as mais competitivas internacionalmente, e o setor de petróleo e gás impulsiona parte significa das manufaturas no país.

A intensidade com que o setor de serviços ganhou força na última década e o declínio das manufaturas têm, entretanto, preocupado o governo britânico. A crise econômica de 2008 demonstrou, em grande medida, que a diversificação da carteira produtiva de um país tende a amortecer os impactos econômicos desfavoráveis externos. Nesse sentido, fortalecer setores ou empresas competitivas do país, como Rolls Royce, Pfizer, Unilever e Land Rover, podem ser o diferencial estratégico para a manutenção de seu desenvolvimento político, econômico e social.

O Reino Unido, desde a década de 1990, estrutura suas políticas industriais tendo como base o fortalecimento da educação, da ciência, tecnologia e inovação, do empreendedorismo e da eficiência produtiva. No ano de 2002, o National Foresight Exercise, estudo prospectivo que orienta a tomada de decisões no país, resultou na elaboração de uma nova estratégia governamental de estímulo do setor industrial que incluía a inserção qualificada do país em cadeias globais de valor e o fortalecimento da pesquisa, do desenvolvimento e da inovação.

A publicação de 2009 Building Britain's Future: New Industry, New Jobs orientou a adoção de novas diretrizes políticas ao fomento da indústria britânica. $O$ governo passou a reconhecer a importância fundamental que as universidades possuíam como locus de empreendedorismo e desenvolvimento de ciência e tecnologia. No ano seguinte (2010), a política industrial britânica passou por nova modernização, enfatizando a conjugação de "ciência, tecnologia e fortalecimento das engenharias" como itens estratégicos ao desenvolvimento do país.

Mais recentemente (2012), novas variáveis foram agregadas à pauta de desenvolvimento da indústria britânica. O Department for Business, Innovation and Skills (BIS) - nota-se que o próprio nome da instituição delimita algumas das diretrizes políticas e industriais do país - no documento Industrial Strategy: UK Sectoral Analysis, enfatiza o forte interesse governamental em estreitar parcerias com o setor

\footnotetext{
${ }^{37}$ Sullivan et al. (2013).
} 
privado industrial para a construção de grupos estratégicos de lideranças no país à definição de prioridades para o desenvolvimento de longo prazo.

O Reino Unido, ainda hoje, apresenta diversas carências políticas no fomento de seu setor industrial, como a recente estruturação do sistema de financiamento. No entanto, o país demonstra que está engajado na construção de uma política nacional de estímulo ao setor industrial, que venha a fomentar setores estratégicos, em sinergia com universidades e setor privado, estimulando a ciência, a tecnologia e a inovação no país.

De acordo com Sullivan et al. (2013), a matriz das políticas industriais do Reino Unido pode ser sintetizada na figura abaixo.

\section{Figura 9 - Matriz das políticas industriais do Reino Unido}

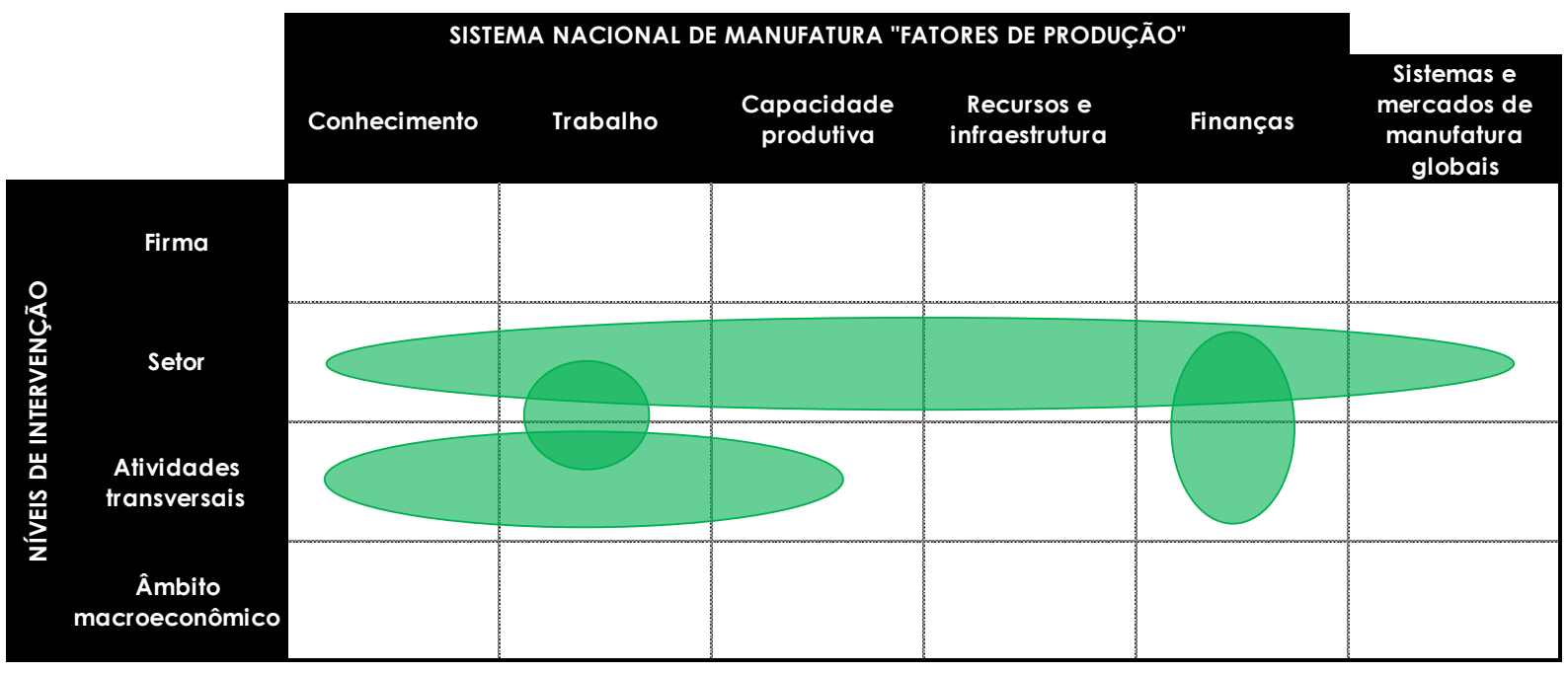

Fonte: Sullivan et al. (2013).

\subsubsection{Políticas industriais dos Estados Unidos}

Os Estados Unidos detêm um dos mais sofisticados e diversificados parques industriais do mundo, com suas manufaturas representando $12 \%$ na composição do PIB em $2013^{38}$, por empregar mais de 11,5 milhões de trabalhadores e contribuir por mais de $60 \%$ do total das exportações do país ${ }^{39}$. A indústria nacional é, em grande

\footnotetext{
38 Dados estratificados por país, estão disponíveis em: http://data.worldbank.org/indicator/NV.IND.MANF.ZS

39 Executive Office of the President (2012). A National Strategic Plan for Advanced Manufacturing. Washington, DC.
} 
medida, baseada no conhecimento científico e tecnológico, que impulsiona setores como química avançada, automotivo, computação, eletroeletrônicos e aeroespacial.

O país é o maior investidor mundial em ciência, tecnologia e inovação, além de ser o locus da maior parte dos pedidos de patentes do planeta, demonstrando que o sistema norte-americano de inovação é um dos principais motores da competitividade da indústria nacional. A inovação do país está alicerçada na sua densa rede de pesquisa, que compreende as melhores universidades do mundo ${ }^{40}$, laboratórios públicos e privados, além de inúmeras agências e departamentos do governo federal, como o Department of Defense, o National Institutes of Health, o National Science Foundation, o National Institute of Standards and Technology, o Department of Defense, Energy and Agriculture, o National Aeronautics and Space Administration, entre outros. Uma indicação da orientação política e industrial do país é o fato de, isoladamente, o Department of Defense ser responsável por aproximadamente metade dos gastos nacionais em $P \& D$, além de ser a instituição responsável pela administração de programas e agência renomadas, como ManTech ${ }^{41}$ e DARPA ${ }^{42}$.

Ao longo das últimas décadas, os Estados Unidos demonstram ampliar ainda mais seus esforços tecnológicos nas áreas de defesa, espaço, saúde, energia e meio ambiente, bem como no adensamento das relações público-privadas, com o objetivo de estimular o empreendedorismo, a inovação e a competitividade da indústria nacional.

A incessante busca pela redução de custos em processos produtivos acabou, entretanto, por deslocar, nas últimas décadas, parcela significativa das manufaturas norte-americanas para países asiáticos, em especial à China, o que tem estimulado a reformulação de políticas que buscam a manutenção de empregos qualificados e, principalmente, a retenção de centros de P\&D no país.

O desenvolvimento de recursos humanos qualificados tem recebido especial atenção por parte do governo federal. Na próxima década, aproximadamente $60 \%$ da

\footnotetext{
40 De acordo com QS World University Rankings 2014/15, os Estados Unidos possuem seis das dez melhores universidades do mundo. Mesmo as universidades privadas, recebem algum tipo de financiamento público, demonstrando a prioridade em gerar e estimular o conhecimento no país.

${ }^{41}$ ManTech - Instituição criada em 1946 pelo governo Americano para suprir carências tecnológicas do setor de defesa. Hoje, a empresa pública desenvolve inovações científicas e tecnológicas aos setores de defesa, inteligência e administração pública.

42 Defense Advanced Research Projects Agency (DARPA) - agência do Departamento de Defesa dos Estados Unidos responsável pelo desenvolvimento de inovações tecnológicas para uso militar.
} 
mão de obra norte-americana responsável pelo desenvolvimento de ciência e pelas engenharias estará apta para aposentadoria, e a atual reposição não logra suprir as demandas do país. Menos de $5 \%$ dos graduados no país são provenientes de ciências e engenharias, comparado aos mais de $10 \%$ em países como Alemanha e mais de $20 \%$ em alguns países asiáticos, como a Coreia do Sul.

Chang (2013) destaca que os Estados Unidos têm priorizado, nas últimas duas décadas, políticas de inovação, em sobreposição às políticas industriais, com o objetivo de promover seu desenvolvimento econômico e social em patamares sustentáveis. A recente publicação Ensuring America Leadership in Advancing Manufacturing ${ }^{43}$ enfatiza que o país deveria evitar a elaboração de políticas industriais triviais, com o fomento de empresas e setores, e apostar em uma política de inovação prioritariamente ousada, o que não deixa de ser uma nova diretriz às políticas industriais do país.

Entretanto, o país adota estratégia de política industrial e de inovação com pouca ou nenhuma coordenação entre as diferentes instituições do governo, tanto no âmbito federal como estadual, com o objetivo de estimular a competitividade entre os entes federados e favorecer aqueles com as melhores iniciativas e estratégias ao desenvolvimento.

Sullivan et al. (2013) sintetizam que os Estados Unidos, independentemente da composição do Congresso e do partido presidencial, buscam priorizar nas políticas industriais da atualidade eminentemente três fatores:

(i) a modernização produtiva e o estímulo à competitividade da indústria, ao promover o conhecimento e o acesso ao financiamento de pequenas e médias empresas nacionais,

(ii) o acesso a mercados internacionais com a celebração de acordos bilaterais de comércio ou no fortalecimento de sua atuação na Organização Mundial do Comércio (OMC) e

(iii) o estímulo à pesquisa, ao desenvolvimento e à inovação de manufaturas avançadas, com financiamento adequado e auxílio de agências e programas governamentais.

43 EOP PCAST (2011). Report to the President on Ensuring American Leadership in Advanced Manufacturing. Washington. DC. Executive Office of the President of the US and President's Council of Advisors on Science and Technology. 
Sullivan et al. (2013) sintetizam a matriz das políticas industriais dos Estados Unidos na figura 10 abaixo.

Figura 10 - Matriz das políticas industriais dos Estados Unidos

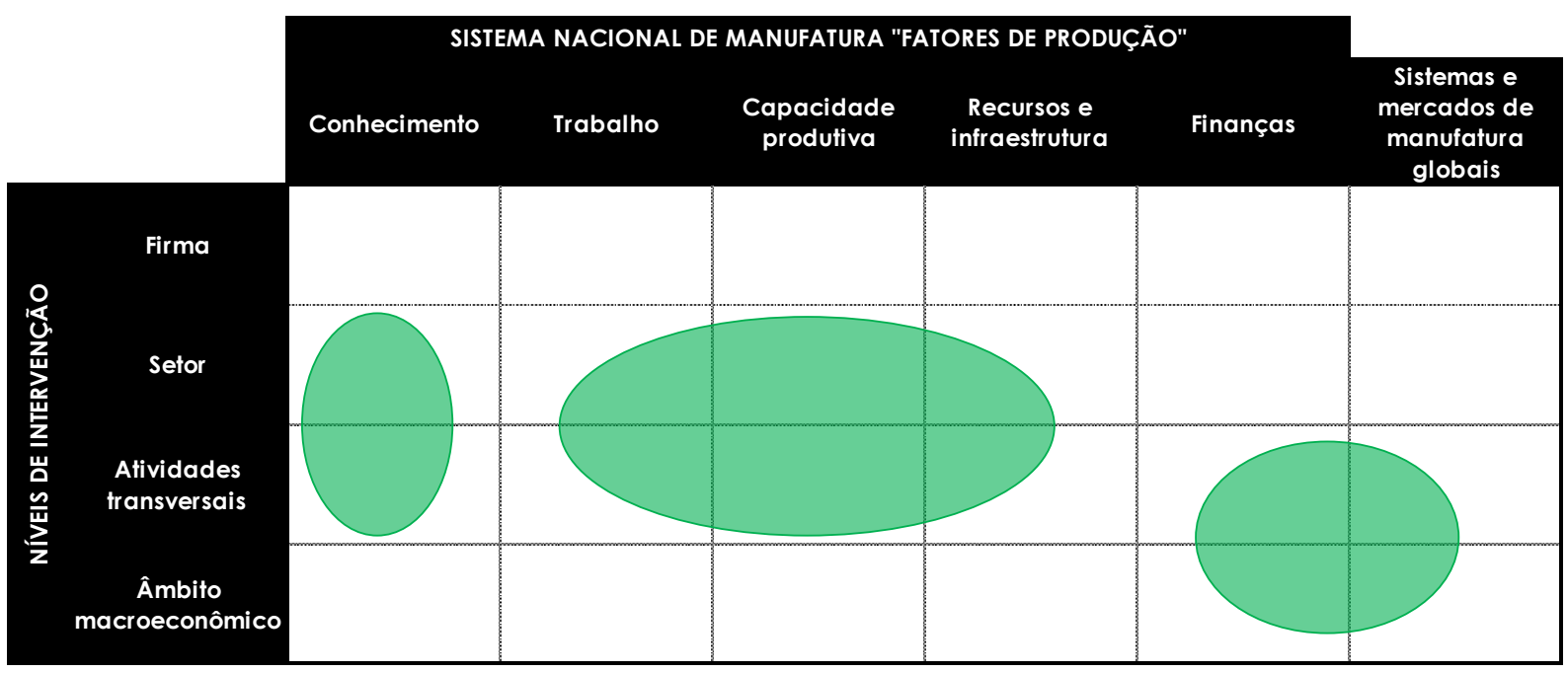

Fonte: Sullivan et al. (2013).

\subsubsection{Políticas industriais da Alemanha}

A Alemanha é reconhecida mundialmente pela qualidade de seus produtos manufaturados, pela eficiência empresarial e alta produtividade de seu setor industrial, que representa mais de $10 \%$ das exportações mundiais de manufaturados. O país é o berço de marcas renomadas em diversos setores e sede de empresas como BMW, Porsche, Audi, Bosch, Siemens, Bayer, BASF, Volkswagen, entre inúmeras outras.

O setor industrial do país é diversificado, tanto no tamanho das empresas, como nas estruturas corporativas. O país, mesmo reconhecido por abrigar grandes empresas e marcas, é composto majoritariamente $(99,6 \%)$ por pequenas e médias empresas, responsáveis por $70 \%$ das exportações e $80 \%$ do emprego gerado no país. Dessas empresas, mais de $90 \%$ são familiares e gerenciadas pelos próprios donos.

A Alemanha é beneficiada pela alta qualidade de seu sistema educacional e de pesquisa científica, propício ao desenvolvimento de novas tecnologias em áreas como mecânica, química, metrologia, controle de qualidade, entre outras. O país é reconhecido por ser polo industrial tanto de bens duráveis, de capital, como não duráveis. Especial destaque deve ser conferido às exportações de máquinas e equipamentos, atrás apenas do Japão, maior exportador mundial no segmento. 
$\mathrm{Na}$ atualidade, a Alemanha se distingue como líder mundial no desenvolvimento de tecnologias para a geração e transmissão de energias renováveis, como solar e eólica. A matriz energética limpa do país alcança índices como $23 \%$, com perspectivas de avançar gradativamente e sustentavelmente no futuro próximo. Dados do Germany Trade \& Investment (GTI) de 2013 revelam que a Alemanha responde por aproximadamente $30 \%$ de toda a energia eólica produzida na Europa e por $12 \%$ de toda a capacidade mundial instalada.

A indústria alemã possui uma estrutura de gestão complexa e descentralizada, com a presença de entidades sindicais, associações de empregados, universidades e centros de pesquisa. As entidades são financiadas direta ou indiretamente pelo governo federal e privilegiam o trabalho em cooperação com o setor privado.

A estrutura industrial alemã, na visão governamental, busca construir e preservar um arcabouço mínimo institucional dedicado ao desenvolvimento de fatores estratégicos ao país, como educação, geração de energia, preservação ambiental e desenvolvimento de tecnologias disruptivas. Demais iniciativas estruturantes devem recair à responsabilidade do setor privado, à medida que a indústria detecta oportunidades de investimento e demandas de mercado.

O setor empresarial alemão e o governo federal atuam conjuntamente na prospecção de oportunidades no exterior, com o objetivo de gerar novos empregos e estimular o desenvolvimento econômico e social do país. Nesse contexto, o governo alemão tem priorizado para a próxima década:

(1) o desenvolvimento de ciência e tecnologia, com vistas ao estímulo do desenvolvimento social;

(2) a minimização das mudanças climáticas, com o incremento de energias limpas e a redução de emissões de gases causadores do efeito estufa;

(3) a ampliação da qualidade nutritiva e da segurança alimentar, melhorando a qualidade de vida de seus cidadãos;

(4) o incremento da mobilidade urbana, ampliando a oferta de transportes públicos limpos e

(5) a manutenção da segurança, inclusive das comunicações, ampliando a defesa do país. 
Ademais, o país busca ampliar suas exportações como medida de estímulo empresarial ao alcance de novos mercados, inclusive por meio de instituição de câmaras bilaterais de comércio com países parceiros e mercados consumidores.

As políticas industriais da Alemanha, de acordo com Sullivan et al. (2013), são ilustradas na matriz 11 abaixo.

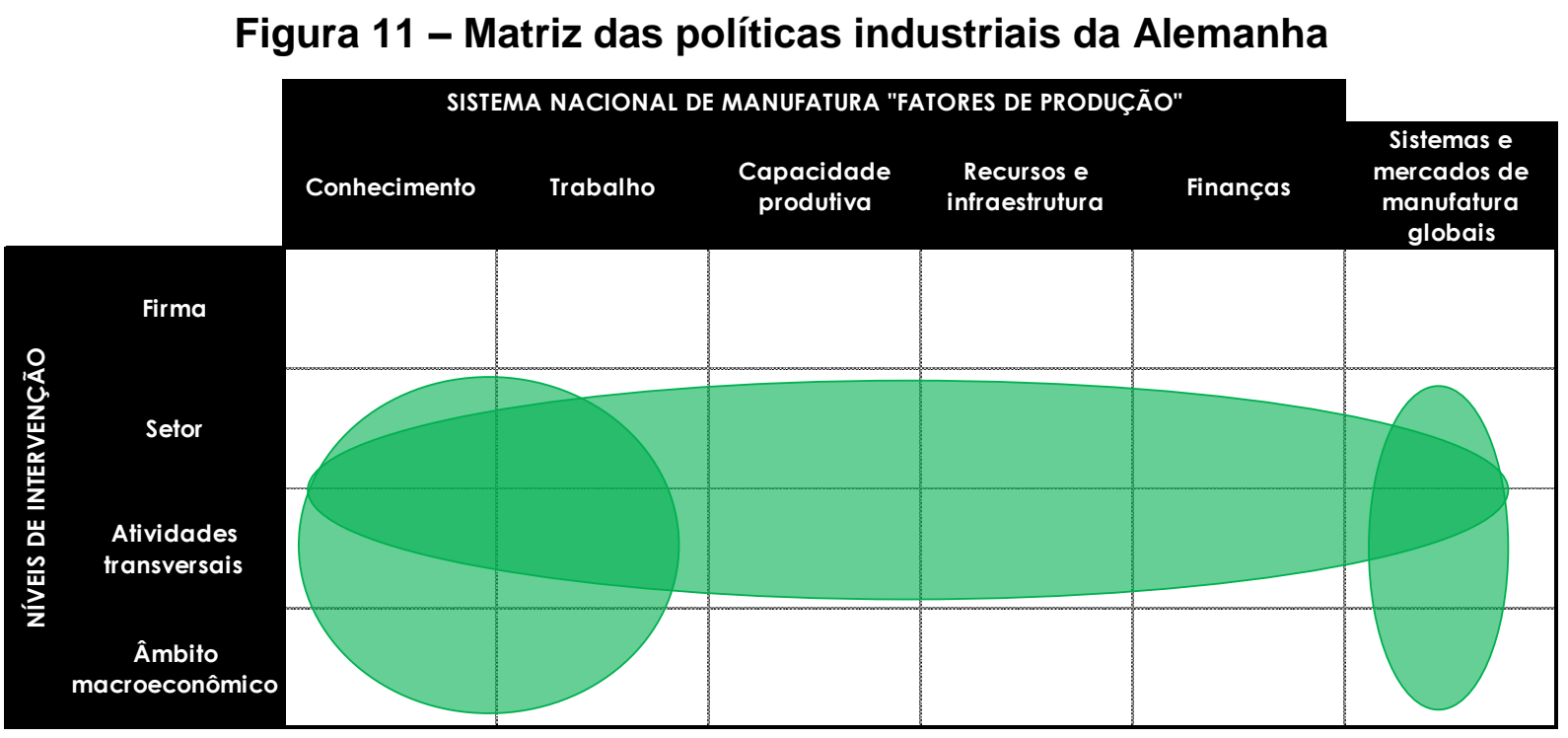

Fonte: Sullivan et al. (2013).

\subsubsection{Políticas industriais do Japão}

O Japão é um dos países mais sofisticados do mundo em termos industriais, com empresas entre as mais avançadas cientificamente e tecnologicamente. $O$ país possui uma forte cultura associada ao processo produtivo, que se reflete na expressão monozukuri, de constante espírito inventivo, inovador e empreendedor.

No país, a indústria automotiva e a eletrônica são dois vetores que mobilizam parte da economia. Para se ter uma ideia da magnitude, o país responde por aproximadamente $30 \%$ da produção mundial de carros. A mecânica e a engenharia de materiais também capitalizam parcela significativa dos empregos nacionais, bem como a manufatura de componentes aeronáuticos, de robôs e de química avançada.

Em duas ocasiões recentes, o país sofreu pesadas instabilidades macroeconômicas, uma com a crise econômica e financeira de 2008 e a outra como consequência do terremoto de março de 2011, que provocou a interrupção de fluxos 
logísticos no continente asiático e no mundo como um todo. O Japão, contudo, tem demonstrado considerável poder de recuperação perante esses fatores adversos.

Cabe destacar que o modelo de gestão empresarial japonês tem sido questionado na atualidade, tendo em conta que grandes conglomerados empresariais (keiretsu) passaram a ter dificuldades na manutenção da produtividade das pequenas e médias empresas que administram. Alega-se que a estrutura piramidal e altamente verticalizada dos conglomerados japoneses (empresas como, Mitsubishi, Mitsui, Sumitomo, entre outras) compromete a competitividade empresarial, a lucratividade e o desenvolvimento de pequenos e médios empreendedores no país.

A dinâmica de redução de custos produtivos mediante a transferência de plantas industriais para países do sudeste asiático e China também afetou drasticamente a indústria japonesa, que se viu prejudicada com a redução de empregos diretos e com a exportação de centros de P\&D, qualificados como vetores da inovação no país. Fujitsu, Nokia, P\&G e Sharp foram apenas algumas das empresas que retiraram seus centros de $P \& D$ do território japonês na última década. Para complicar ainda mais a dinâmica econômica de desenvolvimento por meio do setor industrial, o país possui parcela significativa de sua população economicamente ativa em idade avançada, motivo pelo qual a taxa de reposição da mão de obra não atende as atuais necessidades ao desenvolvimento do país.

Medidas governamentais adotadas nas últimas décadas revelam a orientação industrial do país na busca do desenvolvimento. $O$ antigo Ministério da Indústria e do Comércio Exterior foi incorporado ao Ministério da Economia no ano 2000, passando a chamar-se Ministério da Economia, Indústria e Comércio Exterior. A mudança reflete, sobretudo, o forte interesse governamental em ampliar a transversalidade das políticas, ao possibilitar oportunidades de investimento em setores como a inovação, que alcançou patamar estratégico na gestão governamental japonesa, muito próximo da administração do próprio Primeiro Ministro.

A concentração da indústria nacional no setor automobilístico e de eletrônicos tem sido revisitada pelas atuais políticas industriais japonesas, que buscam fomentar outros cinco setores:

(1) o de infraestruturas;

(2) o de energia, que compreende a construção de cidades inteligentes e a geração de energias limpas; 
(3) o da indústria criativa;

(4) o da saúde e segurança alimentar e

(5) o de tecnologias avançadas, como robótica e aeroespacial.

Segundo Sullivan et al. (2013), o governo japonês almeja, com a modernização desses setores:

(i) tornar-se polo manufatureiro competitivo,

(ii) ampliar a inserção das tecnologias e dos produtos japoneses no mercado mundial e

(iii) solver carências energéticas.

Para alcançar suas novas ambições industriais, o país adota medidas de estímulo fiscal e tarifário, busca a atração de centros de P\&D, amplia os investimentos em logística e infraestruturas e moderniza o sistema de financiamento ao setor produtivo, estimulando startups e pequenos e médios negócios de base tecnológica. Para solver as carências de recursos humanos para o desenvolvimento tecnológico, o país tem realizado pesados investimentos na capacitação de sua mão de obra jovem, na inclusão feminina ao mercado de trabalho e, inclusive, estimulado idosos a ter uma segunda carreira.

A Agência de Cooperação Internacional Japonesa (JICA) tem papel fundamental na inserção internacional do país, inclusive em países em processo de desenvolvimento, onde busca a prospecção de mercados consumidores e parceiros comerciais interessados em firmar acordos de comércio e investimentos.

Com relação à coordenação das políticas, o governo japonês intensifica, cada vez mais, a integração entre os setores público e privado e a academia, com vistas à modernização e criação de novos centros de P\&D no país, que venham a manter e a aprimorar o desenvolvimento econômico e social do país.

As políticas industriais do Japão podem ser sintetizadas na matriz abaixo, segundo Sullivan et al. (2013). 
Figura 12 - Matriz das políticas industriais do Japão

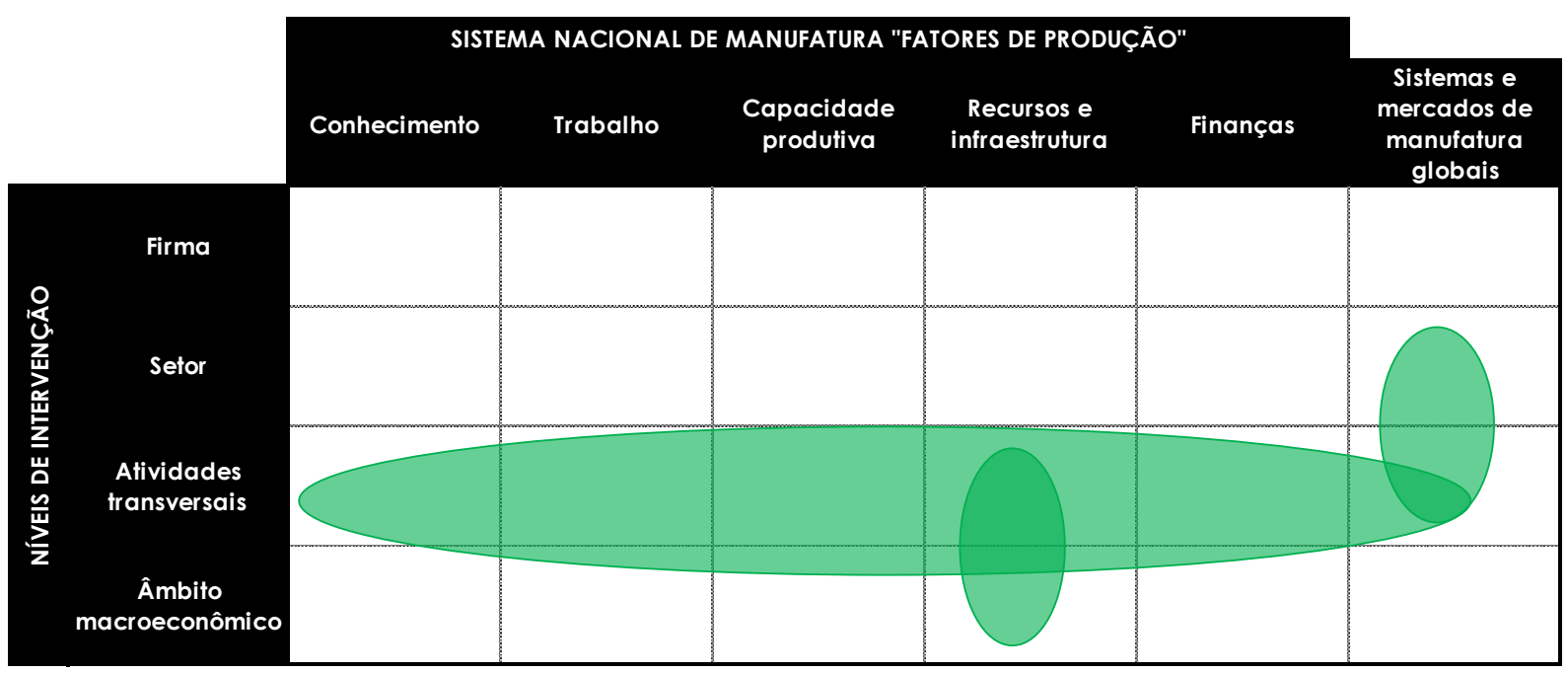

Fonte: Sullivan et al. (2013).

\subsubsection{Síntese das políticas industriais}

A análise das políticas industriais dos países desenvolvidos selecionados em Sullivan et al. (2013) resulta em algumas conclusões gerais a respeito das diretrizes empregadas. Os resultados podem ser detalhados sob três óticas: agendas políticas, fatores de produção e níveis de intervenção.

No quesito "agendas políticas", nota-se o amplo engajamento político de países como os Estados Unidos e Reino Unido em reverter o processo de desindustrialização. No caso dos Estados Unidos, isso ocorre por meio do aprimoramento da pesquisa e do desenvolvimento em associação à atração de processos fabris ao seu território, do estímulo de exportações de alto valor agregado e da melhoria das condições de competitividade da indústria nacional. O Japão, por sua vez, demonstra estar mais direcionado a reestruturar sua matriz produtiva, com o aprimoramento das capacidades industriais e do sistema regulatório ao desenvolvimento de pequenas e médias empresas (PME). A Alemanha, país com sistema de suporte à competitividade de PME avançado e conectado às cadeias globais, procura ampliar seus gastos em P\&D, sob a primazia de políticas orientadas ao desenvolvimento econômico e social do país.

Sob a ótica dos "fatores de produção", essa categoria pode ser subdividida em quatro áreas, quais sejam: conhecimento; trabalho; capacidade produtiva; recursos e infraestrutura; e finanças, conforme matriz desenvolvida por Sullivan et al. (2013): 
Conhecimento: com relação à ênfase dada à geração de conhecimento nas políticas industriais, nota-se claras estratégias de fomento de P\&D e desenvolvimento de manufaturas avançadas. Nos Estados Unidos e no Reino Unido, isso é perceptível com a estratégia de fortalecimento do US National Manufacturing Innovation Institutes e do UK Catapult Technology and Innovation Centres, à semelhança dos German Fraunhofer Institutes, instituições que buscam o desenvolvimento de novas tecnologias e inovações em parceria com o setor empresarial. Essa ênfase também é evidenciada nas políticas japonesas, que contemplam a criação de novos centros de P\&D em um sistema sinergético entre a indústria, a academia e o setor governamental.

Trabalho: ênfase amplamente adotada nas políticas indústrias, quando se destaca as necessidades de ampliação da qualidade e da quantidade de recursos humanos dedicados à inovação e ao desenvolvimento industrial. Destaque especial ocorre às carreiras de engenharia na Alemanha e no Japão, onde parte da população economicamente ativa se encontra em idade avançada para o trabalho. É perceptível, por fim, que a geração de mão de obra qualificada ocorre, em grande medida, em associação aos centros de inovação nacional, disseminados ao longo do território dos países, aprimorando as habilidades necessárias de acordo com as exigências regionais.

Capacidade produtiva: todos os países analisados possuem programas estruturados de suporte ao desenvolvimento de manufaturas em âmbito nacional, com ênfase no auxílio a pequenas e médias empresas no âmbito do desenvolvimento de tecnologias e inovações. É perceptível, ainda, evolução da estratégia antes baseada em lean production ${ }^{44}$ e sistemas de aprimoramento da qualidade produtiva, para algo mais orientado ao estímulo de P\&D, de inovações e da inserção do setor industrial nacional em cadeias globais de valor.

Recursos e infraestrutura: com relação aos desafios impostos pela carência de recursos e infraestruturas, as políticas industriais dos países desenvolvidos buscam priorizar o fomento de novas tecnologias e inovações, em equilíbrio com padrões de sustentabilidade. Como exemplo, no Reino Unido

${ }^{44}$ Lean Production - sistema enxuto de produção industrial, baseado na minimização de perdas e orientado às demandas do cliente. 
e na Alemanha, percebe-se os pesados investimentos públicos e privados para - desenvolvimento de tecnologias limpas, como veículos elétricos, combustíveis renováveis e energias limpas. Os governos chegam a estabelecer metas específicas, como alcançar certo número de carros elétricos em circulação até determinado período, o que demonstra a prioridade no desenvolvimento de ciência, tecnologia e inovação baseadas na sustentabilidade de recursos e infraestruturas.

Finanças: a crise econômica e financeira de 2008 provocou severos impactos no sistema de financiamento ao desenvolvimento industrial dos países desenvolvidos. Nesse sentido, evidenciam-se claras estratégias governamentais de ampliação do investimento privado e do acesso a financiamento público, em especial a pequenas e médias empresas. Bancos nacionais de desenvolvimento possuem especial participação nestas estratégias, pois concedem financiamento de longo prazo, subsídios à exportação, à educação e treinamento, entre outros mecanismos de suporte e desenvolvimento industrial.

A análise dos sistemas e mercados de manufatura globais nas políticas industriais revela, por fim, o interesse estratégico dos desenvolvidos em ampliar exportações, aproximar seu setor industrial de mercados emergentes e integrar sistemas produtivos nas cadeias globais de valor. Os Estados Unidos, por exemplo, instituíram a National Export Initiative a qual visa, além de financiamento às exportações, ampliação de acesso a novos mercados e estímulo a acordos comerciais internacionais, com o objetivo de ampliar a inserção do setor industrial nas cadeias globais de valor de forma qualificada e competitiva.

A análise das políticas industriais dos países desenvolvidos na ótica dos "níveis de intervenção" revela algumas particularidades. Por exemplo, nenhum país analisado busca selecionar empresas campeãs e atuar no nível da firma (figura 13), mesmo com a ocorrência de parcerias público-privadas pontuais em determinados setores. O nível setorial e as atividades transversais são os mais priorizados, quando os países desenvolvidos buscam aprimorar e desenvolver parcerias de longo prazo em setores estratégicos e em atividades transversais, como manufaturas avançadas e pesquisa, desenvolvimento e inovação. Em adição, as políticas industriais contemplam, em alguma medida, diretrizes de âmbito macroeconômico, como reformas tributárias, 
estímulo a acordos comerciais e acesso a mercados, leis de imigração, entre outras iniciativas. Entretanto, privilegiar os aspectos macroeconômicos não demonstrou ser a estratégia primordial nas políticas industriais dos países analisados.

Como ilustração, a figura 13 sobrepõe as ênfases das políticas industriais dos quatro países analisados ao longo desse capítulo, utilizando a metodologia matricial de Sullivan et al. (2013).

Figura 13 - Políticas industriais dos países selecionados - Reino Unido, Estados Unidos, Alemanha e Japão - sobrepostas

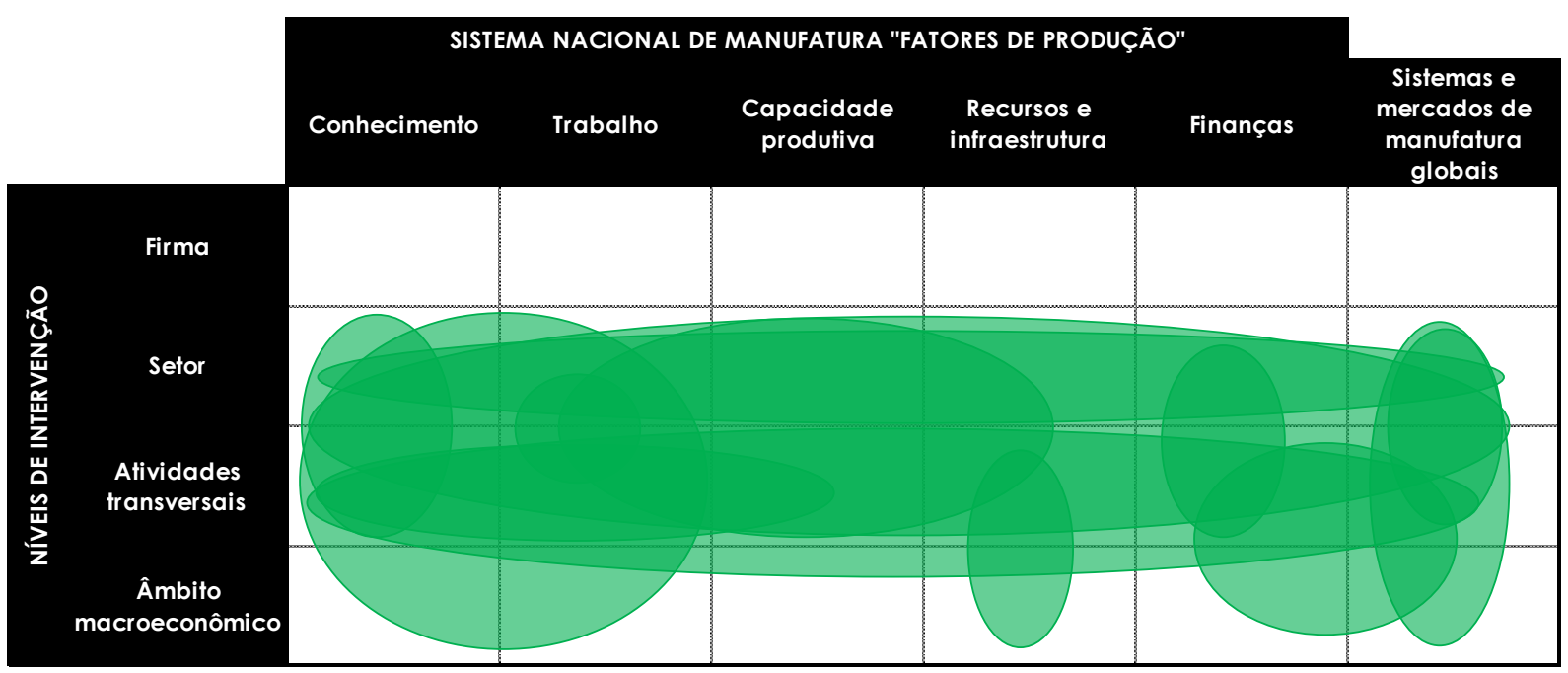

Fonte: Elaborado pelo autor.

A figura 14, por sua vez, sintetiza a análise das tendências nas políticas industriais dos países desenvolvidos selecionados, demonstrando de forma difusa, quais as principais ênfases adotadas pelos países. A figura 14 será a base de comparação com os projetos de desenvolvimento industrial em países em processo de desenvolvimento realizados pela ONUDI, análise que será abordada no item a seguir. 
Figura 14 - Síntese das matrizes das políticas industriais dos países selecionados

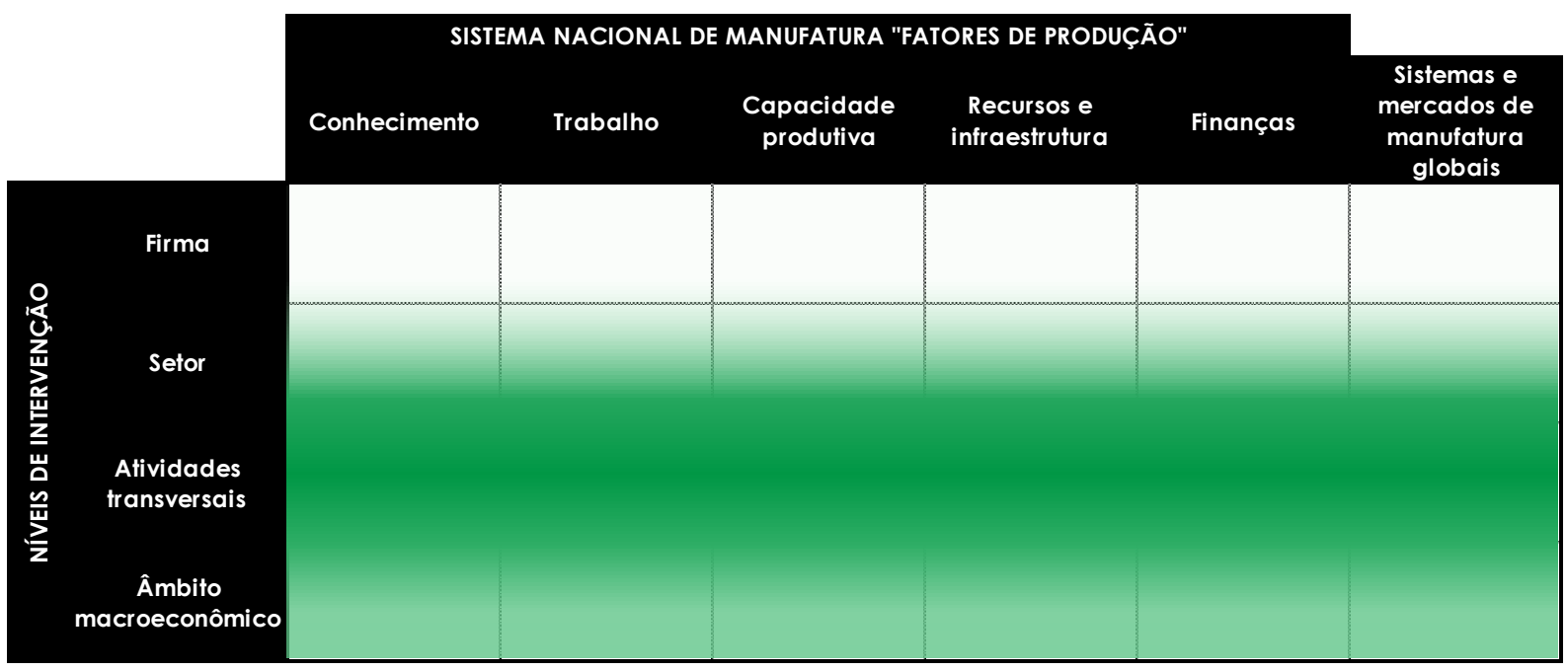

Fonte: Elaborado pelo autor.

\subsection{Os rumos das estratégias da ONUDI}

Mediante a percepção de que o fortalecimento do setor industrial é estratégia fundamental para o desenvolvimento dos Estados, a ONUDI foi criada no âmbito da ONU na segunda metade do século XX. Na atualidade, a organização busca a promoção do desenvolvimento econômico e sustentável em países emergentes e de menor desenvolvimento relativo, servindo como principal foro de diálogo para a disseminação de conhecimento e para suporte técnico em projetos de estímulo do setor industrial.

Recentemente, a ONUDI atualizou seu planejamento estratégico, documento no qual destacou suas estratégias de atuação, quais sejam: promover a cooperação Sul-Sul e triangular, ampliar o emprego de jovens e mulheres, promover o uso e o acesso a energias limpas, estimular a cooperação com organismos internacionais e o setor privado e capacitar países em processos de desenvolvimento industrial. Para a consecução destas diretrizes estratégicas, a agência adota três orientações principais:

(1) reduzir a pobreza de países emergentes e de menor desenvolvimento relativo, com o aprimoramento de suas atividades produtivas; (2) capacitar comercialmente atores e entidades privadas e (3) promover a sustentabilidade ambiental e energética dos países em processo de desenvolvimento. 
Buscando aprofundar seu planejamento estratégico, em 2011, a agência criou grupo de trabalho para debater o futuro da instituição, que elaborou o Documento de Orientação Estratégica IDB 41/24, publicado em junho de 2013, que trouxe algumas das mais recentes orientações sobre o futuro da agência, entre as quais:

- a ONUDI deve promover o desenvolvimento industrial sustentável e a cooperação industrial internacional, tendo como marco suas prioridades temáticas e em comum acordo com os objetivos mundiais, regionais e nacionais de desenvolvimento;

- $\quad$ industrialização e a reindustrilização estão entre os motores principais de desenvolvimento econômico e erradicação da pobreza, sendo que a instituição deve ser o organismo especializado da ONU para: (1) promover o desenvolvimento industrial inclusivo e sustentável, (2) estimular o emprego, (3) ampliar a eficiência ao uso de recursos e de energia, (4) minimizar contaminações e a mudança climática, (5) erradicar a pobreza, (6) ampliar a criação e a transferência de conhecimentos e inovações tecnológicas e (7) reduzir as desigualdades;

- o desenvolvimento industrial inclusivo e sustentável deve contemplar as dimensões econômica, social e ambiental, conforme a necessidade dos Estados-membros;

- a agência deve promover a cooperação industrial Norte-Sul, Sul-Sul e triangular, incluindo a transferência de tecnologias, o estabelecimento de redes de conhecimento, a promoção de alianças empresariais e entre os setores público e privado;

- a ONUDI deve prestar especial dedicação aos países de menor desenvolvimento relativo, particularmente os africanos, com vistas à construção de serviços diferenciados.

Por fim, mas não exaustivamente, o Documento de Orientação Estratégica IDB 41/24 destaca as três prioridades temáticas da agência: criar capacidades produtivas, criar capacidades comerciais, estimular o desenvolvimento produtivo em patamares sustentáveis e a eficiência de uso dos recursos industriais.

Nota-se claramente que as estratégias propugnadas pela agência são, em grande medida, muito similares àquelas adotadas por países desenvolvidos em suas políticas industriais. Nesse sentido, para aprofundar a análise e subsidiar a 
identificação das diretrizes utilizadas pela ONUDI em seus projetos de desenvolvimento industrial, utiliza-se, neste estudo, a mesma estrutura matricial de Sullivan et al. (2013), que parametriza as políticas industriais em níveis de intervenção - firma, setor, atividades transversais, âmbito macroeconômico - e fatores de produção - conhecimento, trabalho, capacidade produtiva, recursos e infraestrutura, finanças -, além dos sistemas e mercados de manufatura globais, que abarcam a orientação internacional das políticas industriais.

Sob a análise dos fatores de produção, mais especificadamente aqueles relacionados ao "conhecimento" e à "capacidade produtiva", a ONUDI procura estimular o crescimento econômico e a criação de empregos, ao buscar o incremento da competitividade e da capacidade industrial, da inovação, do conhecimento e dos vínculos empresariais, em especial aqueles entre pequenas e médias empresas, o que fica evidente no trecho a seguir:

As the primary driver of economic growth and employment creation, productive activities play a central role in the eradication of poverty and the creation of shared prosperity. This priority concentrates on UNIDO's comparative advantage in building productive capacity and enabling value addition through greater industrial competiveness, innovation and business linkages, particularly for small and medium-sized enterprises (SMEs). Bearing this in mind, UNIDO will also carry out activities on post-crisis rehabilitation to strengthen productive capacities and to promote sustainable production, in accordance with the concept of human security and within the mandate of UNIDO. Programmes include:

(a) Business, entrepreneurship, investment and technology services for SMEs;

(b) Agribusiness and rural entrepreneurship development;

(c) Women and youth in productive activities;

(d) Innovation, knowledge-sharing and technology transfer. (UNIDO - IDB 41/24, 2013b, p.05, grifo nosso)

Com relação ao fator de produção "trabalho", a ONUDI estabelece a criação de empregos qualificados entre as estratégias principais de desenvolvimento sustentável. Nesse contexto, a transformação social dos países passa pela 
qualificação de recursos humanos e a consequente criação de novos empregos, em linha com as estratégias dos países desenvolvidos, que buscam conjugar o fator conhecimento à criação de novos empregos qualificados.

Employment creation is at the core of industrial strategies geared to sustainable development. There seems to be consensus that to maximize the benefits of industrialization, labour markets have to generate more and better jobs, which in turn increase real incomes and take people out of poverty. (UNIDO, 2013c, p.151, grifo nosso)

\begin{abstract}
Policy-makers have to create or strengthen skills for industry today while anticipating demand for tomorrow, especially in countries that want to transform their economies. They may need to consider three types of intervention: "early reactive" to tackle immediate skill shortages; "continuing" to tackle the skill demand for upgrading within existing industries; and "future-oriented" to supply the skills for long-term structural change. (Fernandez-Stark, Bamber and Gereffi 2012 apud UNIDO 2013c, p.151, grifo nosso)
\end{abstract}

No quesito "recursos e infraestrutura", a agência procurar reforçar seu objetivo de desenvolvimento industrial em patamares sustentáveis, quando busca estimular a gestão ambiental, a eficiência energética e o desenvolvimento de infraestruturas que facilitem o desenvolvimento industrial dos Estados.

\title{
Sustainable production and industrial resource efficiency
}

This area concentrates on UNIDO's comparative advantage as the specialized agency of the United Nations with expertise in industrial environmental management, industrial energy and resource use. It also acknowledges the Organization's advantage in the industryrelated implementation of multilateral environmental agreements. Programmes include:

(a) Resource-efficient, sustainable and low-carbon industrial production;

(b) Clean and renewable energy access for productive use;

(c) Industrial energy efficiency; 
(d) Capacity-building for the industry-related implementation of multilateral environmental agreements. (UNIDO - IDB 41/24, 2013b, p.06)

Por fim, os projetos da agência procuram estimular o conhecimento sobre facilitação e acesso à financiamento, ao invés da simples concessão de subsídios financeiros a empresas ou instituições, o que completa o fator de produção "finanças" na matriz de Sullivan et al. (2013).

The achievement of all the [Sustainable Development Goals] SDGs, and in particular SDG 9, will be the overarching objective of UNIDO during the implementation period of this [Medium-term programme framework, 2016-2019] MTPF.

$(\ldots)$

\section{Goal 9}

Build resilient infrastructure, promote inclusive and sustainable industrialization and foster innovation.

\section{Targets}

$(\ldots)$

9.3 Increase the access of small-scale industrial and other enterprises, in particular in developing countries, to financial services, including affordable credit, and their integration into value chains and markets. (UNIDO - IDB 43/9, 2015, p.06 e p.35, grifo nosso)

Sob a ótica da inserção dos países em processo de desenvolvimento em cadeias globais de valor, que reflete a orientação "sistemas e mercados de manufatura globais", a ONUDI procura estimular exportações qualificadas, de produtos ou processos de alto valor agregado, respeitando as demandas de consumidores locais e regionais. Com essa finalidade, a agência busca estimular o uso de normas internacionais de qualidade, a consecução de consórcios de pequenas e médias empresas e a disseminação do conceito de responsabilidade social. 


\section{Trade capacity-building}

Accessing markets and engaging in meaningful trading relationships enable countries to make use of their competitive advantages by concentrating their resources into those productive activities that provide the highest economic and social returns. This priority concentrates on UNIDO's comparative advantage in building trade capacity, particularly through facilitating the compliance of SMEs in developing countries to international quality standards and product traceability, and through establishing quality and compliance infrastructure. Programmes include:

(a) Meeting market standards;

(b) Quality and compliance infrastructure;

(c) Industrial export promotion and SME consortia;

(d) Corporate social responsibility for market integration. (UNIDO - IDB 41/24, 2013b, p.05)

Destaca-se, entretanto, que a recomendação utilizada pela ONUDI de intervenção no nível da firma, aos países em processo de desenvolvimento, é divergente das políticas industriais utilizadas pelos países desenvolvidos:

Firm-level interventions are at the heart of industrial upgrading (IU) projects. Evaluations found that assuring flexibility and management ownership are critical for such interventions. The inherent limitations of firm-level interventions need to be recognized in order to avoid "lifting up" some randomly selected individual firms, which is insufficient to reach systemic impact. Such a limited understanding of firm-level interventions has, however, been observed in some "classical" IU projects. (UNIDO, 2013, p. xii, grifo nosso)

UNIDO should revisit the rationale for firm level interventions in the light of the "new structural economics" paradigm to ensure systemic impact and structural change. The decision to what extent a "new structural economic" approach should be adopted is a political decision to be made by the respective partner 
country. But UNIDO should be able to provide valuable advice for decision making. (UNIDO, 2013d, p.105, grifo nosso)

O documento Independent Thematic Evaluation: Thematic Evaluation of UNIDO projects related to "Industrial Upgrading", que avalia os projetos da agência, deixa evidente que a organização necessita revisitar seu nível de intervenção que continua a priorizar firmas - empresas ou parceiros específicos -, mesmo à luz das novas dinâmicas econômicas e sociais existentes. A estratégia reforça, ainda mais, a necessidade de que os projetos de desenvolvimento industrial realizados pela ONUDI sejam elaborados em consonância com as estratégias e a coordenação nacional, para que o país receptor promova seu desenvolvimento em âmbito global.

Seguindo a estrutura matricial de Sullivan et al. (2013), as orientações existentes nos projetos da ONUDI podem ser, portanto, sintetizadas na figura abaixo.

Figura 15 - Matriz das diretrizes da ONUDI

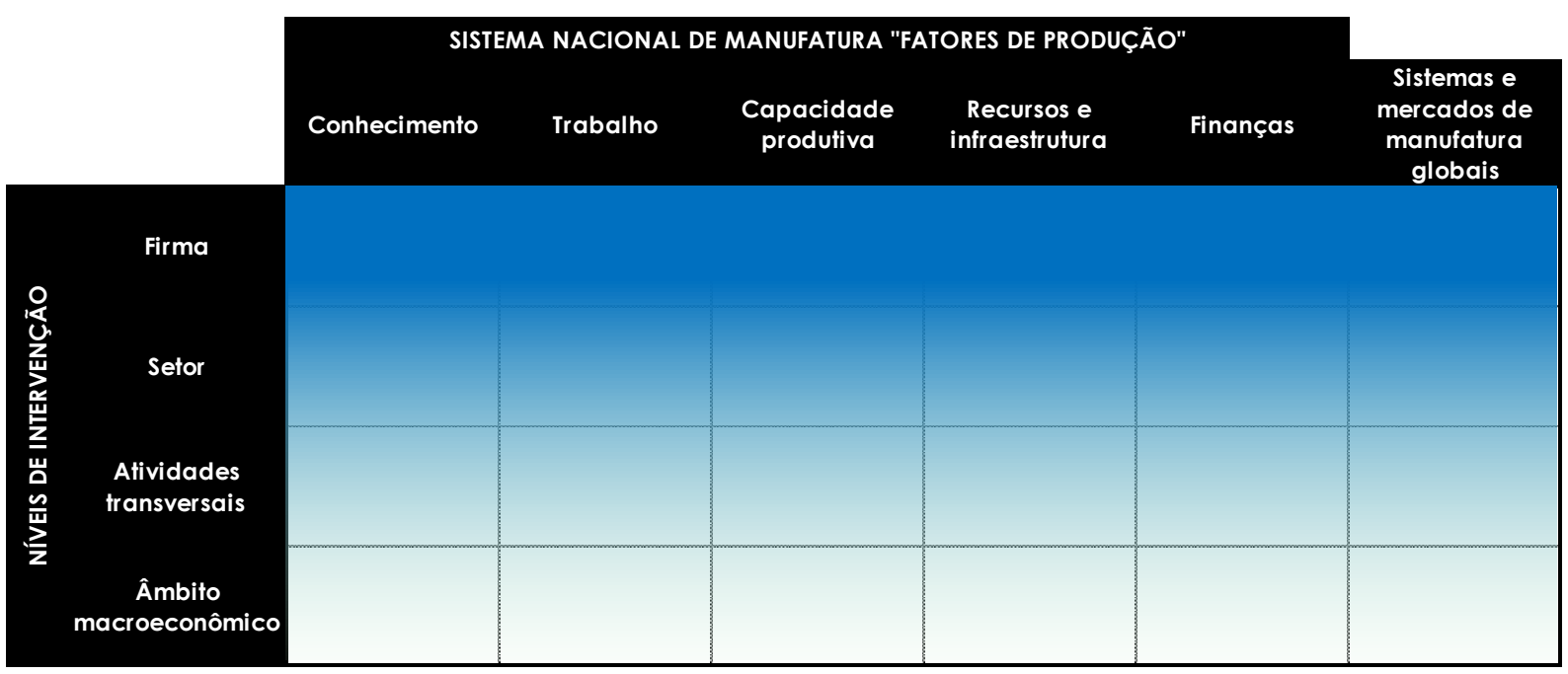

Fonte: Elaborado pelo autor.

Enquanto que a correlação final entre os projetos da ONUDI (figura 15) e a síntese das políticas industriais dos países desenvolvidos (figura 14) podem ser representados na figura 16. As políticas industriais dos países desenvolvidos selecionados comparadas com as orientações da agência deixam evidente as disparidades existentes nos níveis de intervenção, o que será analisado detidamente no capítulo a seguir. 
Figura 16 - Matriz das políticas industriais de países desenvolvidos (verde) versus as diretrizes da ONUDI (azul)

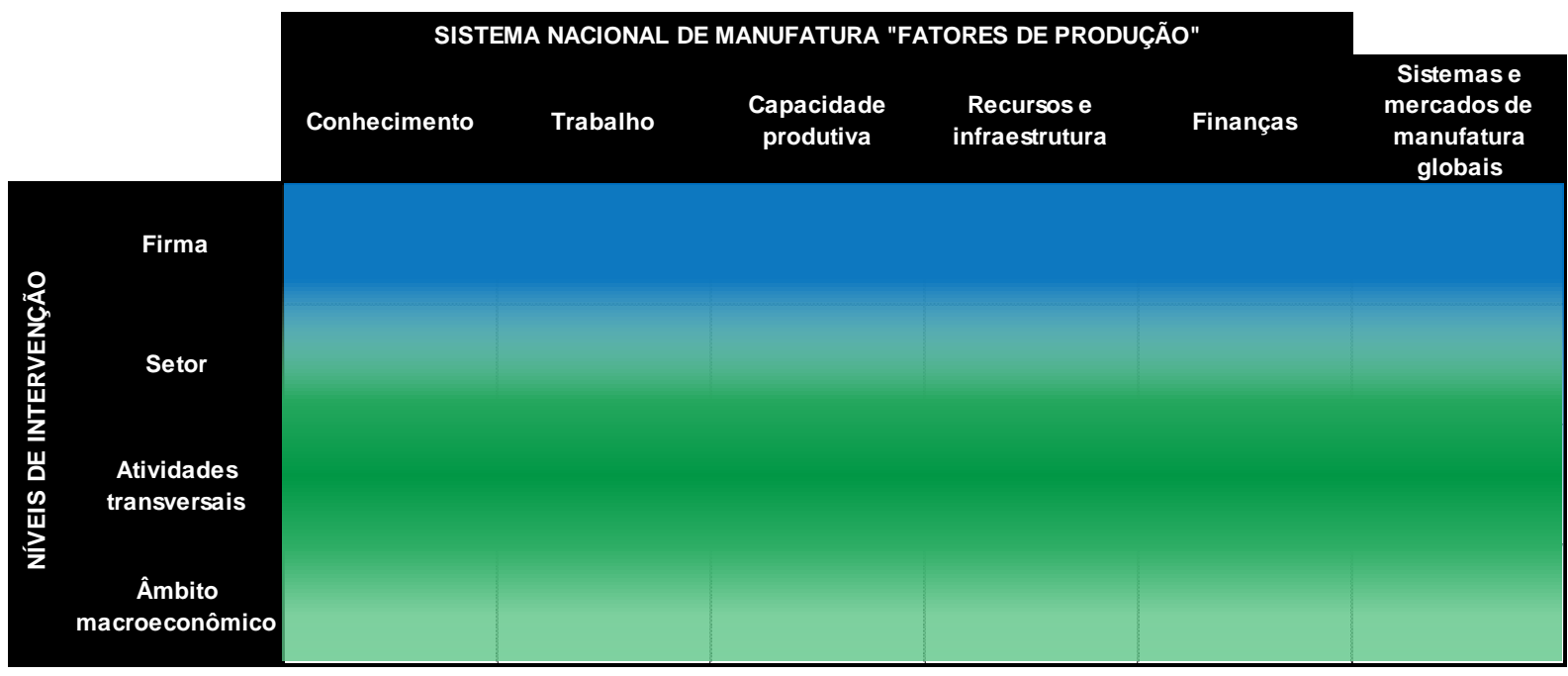

Fonte: Elaborado pelo autor. 


\section{NOVAS POLÍTICAS INDUSTRIAIS E A TRANSFORMAÇÃO SOCIAL}

\subsection{A estratégia para o desenvolvimento e as novas políticas industriais}

Analisar as políticas industriais dos quatro países selecionados - Estados Unidos, Reino Unido, Japão e Alemanha - conduz a algumas conclusões preliminares.

Existem países no cenário internacional, como Estados Unidos e Reino Unido, por exemplo, que buscam contornar o processo de desindustrialização, adotando medidas que promovam a competitividade do setor, o aumento das exportações e o fomento da pesquisa, do desenvolvimento e da inovação nos processos produtivos. No caso específico dos Estados Unidos e do Reino Unido, apesar de ambos não possuírem uma política industrial formalizada, podem ser claramente identificadas estratégias de estímulo à inovação orientadas ao adensamento de setores prioritários, como biotecnologia, nanotecnologia, energias limpas, manufatura avançada, entre outros setores.

Sob outra orientação, existem países, como o Japão e a Alemanha, que buscam aprimorar a estrutura industrial, por meio do estímulo da competitividade de pequenas e médias empresas, ampliando a participação em mercados globais, o financiamento à PD\&l e a coordenação entre setores privados, públicos e academia. No caso do Japão, o país recentemente formalizou uma nova política industrial que retira a ênfase dos setores automobilísticos e de eletrônicos para outros cinco setores: infraestruturas para exportações; energias limpas; cultura (incluindo indústrias e serviços relacionados a moda, turismo e gastronomia); indústria médica e de saúde; e tecnologias avançadas, como robótica e espacial.

As estratégias adotadas pelos quatro países não encerram as opções de novas políticas industriais, mas ilustram que o futuro do setor industrial e as políticas de fomento do setor serão, cada vez mais, difusas, reforçando as vantagens e solvendo as desvantagens, em termos econômicos e sociais, de cada país.

Sullivan et al. (2013) sintetizam as tendências presentes nas novas políticas industriais de países desenvolvidos. Entre as estratégias adotadas estão a busca pelo estímulo constante do conhecimento, da capacidade produtiva, dos recursos 
humanos, dos recursos energéticos, do sistema de financiamento e da inserção em mercados globais, priorizando principalmente o nível setorial e transversal.

Traçando um comparativo com as estratégias da ONUDI, a agência reconhece a relevância de fatores similares de estímulo da produção e os níveis diferenciados de intervenção industrial para a promoção do desenvolvimento. Mesmo assim, contínua priorizando um nível de intervenção mais pontual, no nível da firma (figura 15). Por vezes porque (1) tem dificuldades de estruturar seus projetos em consonância com os interesses estatais, por vezes porque (2) possui pouco orçamento para uma intervenção mais ampla, ou, até mesmo, pelo fato de (3) não se tratar da estratégia fundamental da intervenção, fazendo com que a agência atue superficialmente no desenvolvimento do setor industrial.

O documento Independent Thematic Evaluation: Thematic Evaluation of UNIDO projects related to "Industrial Upgrading", elaborado pela própria agência em 2013, busca apresentar soluções ao fato de que a agência tem dificuldades em estruturar seus projetos em consonância com os interesses dos Estados em que atua:

UNIDO should clarify the rationale for intervening at regional level and ensure complementarity of regional and national [Industrial Upgrading] IU programmes. The [Thematic Evaluation] TE found duplications and even frictions between regional and national IU programmes. At the same time, regional programmes had difficulties to demonstrate their genuine added value at regional level. (UNIDO, 2013c, p. 106, grifo nosso)

UNIDO should develop its competitive advantage as a "honest broker" and strive for a more prominent role as a facilitator. IU involves contributions from many parties, not only inside but also outside the UNIDO mandate. Taking into account the "big picture" and is therefore key for IU interventions to become effective. However, the TE found that coordination and governance mechanisms exist but overview of and coordination with national programmes and other donors' interventions remain limited. UNIDO's IU initiatives should therefore stress the importance of external coordination, links to national level policies and programmes, and the involvement of the private sector, i.e. 
national and regional business associations. To highlight the multiactor dynamics of IU interventions in different environments, this TE has experimented with [Systems Dynamics] SD modelling which could be taken forward for generic IU interventions. (UNIDO, 2013c, p. 107, grifo nosso)

As afirmações presentes no documento deixam claras as oportunidades de melhoria nos projetos da agência. Existem duplicidades entre iniciativas, atritos entre programas e falta de coordenação entre os projetos da ONUDI e as políticas existentes nos países em que a agência atua. Essas deficiências comprometem a efetividade dos projetos, pois criam novos obstáculos ao aprimoramento do setor industrial.

Documentos elaborados pela própria instituição deixam também evidente a carência de recursos por que passa a organização, o que pode ser um indicativo da dificuldade de atuação da agência em outros níveis que não apenas o da firma.

As in the previous biennium, the programmes proposed in the programme and budgets 2014-2015 will need to be undertaken within the limited resources at the disposal of the Organization. The Programme and Budgets, 2014-2015 are presented at a level of 2.6 per cent reduction rate, in real terms. However, the regular budget was reduced by 5.2 per cent, in compliance with the relevant decision of the Industrial Development Board. (UNIDO, 2013c, p.8, grifo nosso)

In light of constraints on the regular budget due to the withdrawal of Member States from the Organization and possible constraints on the operational budget in the future, UNIDO is to identify and optimize under-utilized resources and pursue innovative sources of financing, while seeking to further generate savings. UNIDO is also to negotiate for continued or increased allocations under various multilateral environmental agreements, to seek additional contributions from traditional and emerging multilateral or bilateral sources, with particular attention to decentralized funding sources. (UNIDO - IDB 41/24, 2013b, p.07) 
Entretanto, responder à terceira hipótese levantada preliminarmente, aquela de que a agência prioriza o nível da firma, com o objetivo de promover apenas superficialmente o desenvolvimento dos Estados, exige um nível maior de acesso ao processo de tomada de decisões da agência. Mesmo sendo o argumento central de Chang (2008), de que países desenvolvidos buscam a manutenção do status quo inclusive com atuação em organizações internacionais, a hipótese não é objeto de análise deste estudo, que busca encontrar alternativas à promoção do desenvolvimento com o estímulo do setor industrial. Parte-se da premissa de que cada Estado em processo de desenvolvimento deve "construir sua própria escada", ao identificar suas deficiências econômicas, sociais e políticas, independentemente do que organizações ou demais países venham a promover.

Para aprofundar as estratégias de desenvolvimento e contribuir para a construção de "novas escadas", Warwick e Nolan (2014) fazem um prognóstico sobre as características das novas políticas industriais, enunciando particularidades, como:

A greater emphasis on improving systems and in particular interventions aimed at building networks, improving co-ordination, promoting awareness and securing strategic alignment, including more use of strategic partnerships with industry and joint consideration of the competitiveness challenges facing business;

Notwithstanding the continued use of sectoral targeting in some countries, a shift of focus towards tasks/activities and technologies, and away from support for single firms, national champions, tariff protection and other product market-focused interventions;

At a time of fiscal austerity, less reliance on direct support in the form of state aids and market-failure correcting subsidies; and

Some merging of the boundaries between strategic and defensive industrial policy - while policy makers have reacted to the global crisis by adopting defensive measures where industry has faced acute finance constraints and/or demand pressures, there are also many examples of more strategic interventions in support of new areas of activity. (WARWICK; NOLAN, 2014, p. 41, grifo nosso) 
Nota-se pela análise dos autores que a estratégia de elaboração das novas políticas industriais estará cada vez mais distante do estímulo direto do setor industrial no nível da firma, aprimorando o uso de estratégias mais difusas, fragmentadas e baseadas na cooperação sinergética entre entes públicos e privados. Mazzucato (2013) apud Warwick e Nolan (2014), e Rodrik (2004) aprofundam a análise, ao destacar que aqueles ambientes estatais que estimularem a interação entre entes públicos-privados serão os mais propícios ao desenvolvimento por meio da industrialização.

Mazzucato (2013) has also stressed the importance of public-private partnerships in modern capitalist economies and argued that the role of the state should not be seen purely as derisking or market-failure correcting, but that it can and should play an entrepreneurial role, taking the lead in the development of new technologies, such as green technology, just as it has done in the past with the Internet, agricultural science, bio-technology and nanotechnology. (WARWICK; NOLAN, 2014, p. 42, grifo nosso)

The right model for industrial policy is not that of an autonomous government applying Pigovian taxes ${ }^{45}$ or subsidies, but of strategic collaboration between the private sector and the government with the aim of uncovering where the most significant obstacles to restructuring lie and what type of interventions are most likely to remove them. (RODRIK, 2004, p. 3, grifo nosso)

Em adição, solver a questão do desenvolvimento sob o viés do estímulo industrial requer também dos países uma análise mais profunda de sua realidade e de sua capacidade de "transformação social". Nas palavras de Stiglitz (1998):

Development represents a transformation of society, a movement from traditional relations, traditional ways of thinking,

45 Taxa Pigouviana - conceito de Arthur Cecil Pigou, que corresponde a uma taxa a ser paga como forma de compensar uma externalidade negativa. Por exemplo, uma indústria poluente deveria arcar com os custos de sua poluição, com o objetivo de compensar as externalidades negativas de sua atividade econômica. 
traditional ways of dealing with health and education, traditional methods of production, to more "modern" ways. (STIGLITZ, 1998, p. 3, grifo nosso)

Essa capacidade de "transformação social" passa pela criação de um ambiente mais interconectado e propício às mudanças constantes, de engajamento entre os setores público-privado e acadêmico e de maior produtividade, com o costume do uso da ciência e da inovação para a solução de demandas locais, regionais ou nacionais. Como resultado, essa "transformação social" será maximizada naqueles países que conseguirem construir ou aprimorar, preliminarmente à implementação de suas políticas industriais, um ecossistema básico propício ao seu desenvolvimento, sanando carências institucionais ainda presentes.

O aspecto relevante a ser considerado nesta pesquisa é que a tomada de consciência sobre a necessidade de criação deste ecossistema é a estratégia passível de reverter ou minimizar o status quo, que amplia a divergência de renda entre países desenvolvidos e aqueles em processo de desenvolvimento. Mesmo que o mundo em desenvolvimento não esteja ainda apto à produção de bens de alto valor agregado e plenamente inserido na era do conhecimento, a construção deste ecossistema propiciará as lentes necessárias para que possam vislumbrar o que pode vir a ser o seu desenvolvimento no futuro.

No próximo item, a estruturação deste ecossistema básico ao desenvolvimento industrial será abordada em maior profundidade.

\subsection{Ecossistema básico ao desenvolvimento}

O fomento de um ecossistema básico ao desenvolvimento, preliminar à implementação das políticas industriais ou consecução de projetos industriais, como os da ONUDI, tem por objetivo ampliar a efetividade e a sustentabilidade dessas iniciativas de fomento ao desenvolvimento. Sob outra ótica, a efetividade do desenvolvimento a partir do estímulo do setor industrial dependerá do nível de amadurecimento do ecossistema básico presente em um país, ou do equilíbrio social propício à construção desse desenvolvimento.

Robinson (2009) assim descreve: 
Variation in the adoption of industrial policy or in its success or failure has less to do with ideas or economists, though these can important in particular circumstances, and much more to do with the nature of the political equilibrium in society - which interests are mobilized, what their interests are, what are the political institutions, etc. Understanding comparative policy is thus an exercise in comparative politics. This is a difficult exercise and we are far from having a satisfactory framework which can explain policy and outcome variation but we certainly will never have such a framework until we start thinking about the issues in the right way. (ROBINSON, 2009, p. 9, grifo nosso)

Robinson (2009) destaca ainda que o desenvolvimento industrial deve equalizar "interesses" e "instituições" sob um mesmo arcabouço estratégico, com o objetivo de promover um desenvolvimento que seja sustentável. Essa construção só é possível, quando está presente um ecossistema básico minimamente estruturado no país que se deseja desenvolver, em padrões próximos ou similares ao que se realiza em países desenvolvidos. Caso contrário, a promoção do desenvolvimento não será efetiva, afinal, o país que se deseja desenvolver ainda enfrenta carências básicas que, muitas vezes, o impedem de alcançar patamares mais elevados de desenvolvimento.

Sullivan et al. (2013) destacam os pressupostos de um ecossistema básico propício ao desenvolvimento por meio do estímulo do setor industrial. Segundo os autores, entre as ênfases estariam presentes:

- Conhecimento - Entre as estratégias e as tendências de políticas industriais para o desenvolvimento mais prementes, estão aquelas correlacionadas ao estímulo da pesquisa, do desenvolvimento e da inovação. Nesse sentido, possuir uma estrutura educacional propícia ao conhecimento reforça o desenvolvimento de novas políticas industriais. Nos Estados Unidos e no Reino Unido, por exemplo, a questão é tão relevante para o desenvolvimento da indústria nacional que estimulou a criação de instituições dedicadas ao tema. No Reino Unido, a Catapult, e nos Estados Unidos, o US National Manufacturing Institutes, buscam 
estimular a PD\&l, alavancar novos negócios, bem como inserir as empresas nacionais em cadeias globais de valor.

- Recursos Humanos - A questão da carência quantitativa e qualitativa de recursos humanos é uma constante nas estratégias industriais dos países na atualidade. Em diversos países desenvolvidos o tema é intensificado pela idade média avançada da população economicamente ativa e pelas baixas taxas de reposição. As diferenças recaem sobre a responsabilidade das estratégias de fomento educacional, quando, em alguns países, o próprio setor privado compromete-se com o treinamento de recursos humanos, ao passo que em outros o setor público ainda é o principal idealizador das iniciativas em prol da educação.

- Capacidade Produtiva - Países desenvolvidos criam programas de suporte a pequenas e médias empresas de base tecnológica com 0 objetivo de aprimorar a gestão e a sustentabilidade de seus processos produtivos e a capacidade de exportação a novos mercados consumidores. Como exemplos, existem os programas gerenciados por instituições como Kosetsushi Centres, no Japão; Fraunhofer Institutes and Steinbeis Centres, na Alemanha; Manufacturing Advisory Service, no Reino Unido e Manufacturing Extension Partnership, nos Estados Unidos.

- Recursos Energéticos - A sustentabilidade e a eficiência dos recursos energéticos e das tecnologias produtivas limpas aparecem com grande frequência entre as estratégias de política industrial de países desenvolvidos. Nesse contexto, criar uma estratégia energética nacional tende a reforçar o ecossistema básico propício ao desenvolvimento. Em 2003, por exemplo, o governo inglês promoveu a Low Carbon Vehicles Partnership, iniciativa de fomento industrial que estimula parcerias entre os setores público e privado de diversos segmentos industriais, com o objetivo de desenvolver tecnologias automotivas de baixo impacto ambiental. A iniciativa ganhou relevo na última década, com a UK Low 
Carbon Industrial Strategy, de 2009, demonstrando que o país utiliza a economia verde também como estratégia de aprimoramento de sua matriz industrial.

- Sistema de Financiamento - Em especial após a crise econômica e financeira de 2008, a estruturação de um sistema adequado de financiamento, principalmente às pequenas e médias empresas, é essencial para o desenvolvimento do setor industrial. No Japão, por exemplo, o Japan Finance Corporation e o Japanese Bank for International Cooperation concedem financiamento de longo prazo, tanto para investimentos estrangeiros como projetos cooperativos, principalmente envolvendo pequenas e médias empresas. De Forma muito semelhante, o Export / Import Bank auxilia o financiamento de pequenas e médias empresas de base tecnológica nos Estados Unidos, com o objetivo de alavancar as que ainda não possuem estrutura mínima que lhe garanta a sustentabilidade no mercado industrial, cada vez mais competitivo.

- Inserção em Mercados Globais - Inserir o sistema produtivo de um país em mercados globais passa pelo processo de estímulo às exportações, aproximação a novos mercados e integração em sistemas de manufatura internacionais. A National Export Initiative, ação de estímulo industrial promovida pelo governo dos Estados Unidos, busca não apenas promover o financiamento e estimular as exportações de PME americanas, mas também ampliar o acesso a novos mercados, celebrar acordos comerciais e atrair processos produtivos e centros de PD\&I ao país. Nota-se que fomentar o setor industrial como estratégia ao desenvolvimento passa pela concepção, de que o país deve tanto conhecer suas potencialidades como reconhecer o contexto que o cerca.

Apesar dos países desenvolvidos analisados explorarem novas formas de estímulo do setor industrial, com a exceção de algumas particularidades de acordo com o seu contexto e realidade de desenvolvimento, nota-se uma relativa convergência na importância empregada ao desenvolvimento de $P \& D$ associado às 
manufaturas; o forte incremento de políticas de estímulo aos recursos humanos para inovação, como as engenharias; a promoção da eficiência energética e de recursos empregados no fortalecimento de manufaturas em patamares sustentáveis; o acesso facilitado ao financiamento de pequenos, médios e grandes empresas no setor industrial e, por fim, e talvez mais importante, o forte empenho governamental na coordenação e alinhamento entre as estratégias de desenvolvimento industrial em parceria com o setor privado e a academia.

De forma muito semelhante, o Annual Report 2014 da ONUDI, que compila os principais resultados alcançados pela agência no ano, destaca que a organização prioriza agendas de trabalho muito semelhantes às então realizadas por países desenvolvidos. De acordo com o relatório, a agência tem buscado ampliar a competitividade do setor industrial de países em processo de desenvolvimento, auxiliando países no aprimoramento de seus recursos humanos, no desenvolvimento tecnológico e inovador, com especial ênfase nas pequenas e médias empresas, na disseminação de uma matriz energética limpa e na inserção dos países em processo de desenvolvimento aos mercados internacionais e às cadeias globais de valor.

A ONUDI, entretanto, suporta apenas relativamente a estruturação de sistemas nacionais de apoio às manufaturas, a fim de superar os desafios e alavancar as oportunidades que as mudanças constantes no setor têm exigido, tanto de países desenvolvidos como daqueles em processo de desenvolvimento. A agência pode atuar em nível local, no nível da firma, mas, sobretudo, poderia suportar os países em processo de desenvolvimento a pensarem globalmente, de forma estruturada e consciente em relação a sua condição diferenciada no sistema internacional. Caso contrário, os projetos de desenvolvimento industrial realizados pela agência seguirão diretrizes muito similares àquelas realizadas pelos países desenvolvidos, provocando a manutenção e até mesmo o incremento das desigualdades e da divergência de renda entre desenvolvidos e aqueles em desenvolvimento.

Portanto, além de estabelecer novas estratégias de políticas industriais, os países em processo de desenvolvimento necessitam solver suas carências econômicas e sociais básicas. O aprimoramento desse "ecossistema básico" permitirá, portanto, o desenvolvimento particular de cada país, em linha com suas necessidades particulares de transformação social. 


\subsection{Proposta conjuntural ao desenvolvimento do ecossistema básico}

Kenneth Waltz, autor da obra "Man, the State, and War" de 1959, pensador das relações internacionais e cientista político renomado, enuncia que a política internacional bem estruturada deve responder a três níveis de análise, a saber: as ações de indivíduos, as ações dos Estados e as ações do sistema internacional. As "três imagens" que o autor utiliza para estruturar as políticas internacionais, podem servir de base para a estruturação de propostas de políticas industriais sólidas, realizadas tanto por governos, como instituições não governamentais ou internacionais, como a ONUDI.

Após a análise comparativa das políticas industriais dos quatro países desenvolvidos selecionados e das orientações políticas da agência da ONU para o desenvolvimento industrial, concluiu-se que as principais diretrizes são muito similares. Entretanto, é imprescindível destacar que os países em processo de desenvolvimento ainda estão muito distantes dos níveis de igualdade econômica e social alcançados por países desenvolvidos e, portanto, soluções iguais para realidades diferentes só intensificarão a divergência de renda e as desigualdades nacionais e internacionais entre os países.

Cabe, assim, aos países que almejam o desenvolvimento por meio do fortalecimento do setor industrial a estruturação de um ecossistema básico, que contemple todos os níveis de análise de Kenneth Waltz. As "três imagens", ao nível dos homens, do Estado e do sistema internacional, se contempladas na formulação das políticas industriais, demonstrarão que os países em processo de desenvolvimento, além de se preparar para acompanhar as tendências industriais, estarão aptos a contornar carências sociais e econômicas, resultantes de um processo de constituição estatal deficiente.

Stiglitz (1998) evidencia ideia semelhante quando enuncia:

While the details of a development strategy will differ from country to country, one constant is that since a development strategy outlines an approach to the transformation of society, it must address all components of society. (STIGLITZ, 1998, p. 24, grifo nosso) 
In particular, a strategy must include components aimed at developing the private sector, the state (the public sector), the community, the family, and the individual. The different components of the development strategy are intricately interrelated. (STIGLITZ, 1998, p. 24, grifo nosso)

Ao nível dos homens, por exemplo, os países em processo de desenvolvimento ainda carecem de uma democracia estruturada, que venha a dar unicidade aos interesses de seus cidadãos. Aspectos como preservação ambiental, conservação e respeito ao meio ambiente, para que gerações futuras desfrutem, pelo menos, da mesma qualidade de vida que a atual, deveriam ser uniformemente incorporados pela sociedade. Ainda, ao nível dos homens, o mundo desenvolvido concede liberdades culturais, sociais e econômicas não plenamente estruturadas no mundo em processo de desenvolvimento.

Stiglitz (1998) assim descreve:

In the end, the transformation of society entails a transformation of the way individuals think and behave. Development entails the empowerment of individuals, so that they have more control over the forces that affect their lives, so that they can have a richer, healthier life. Education and health are at the center of efforts at individual development. (STIGLITZ, 1998, p. 27)

Ao nível do Estado, países desenvolvidos controlam com maior eficiência práticas de corrupção e são mais abertos ao debate sobre a ética. Isso ocorre na medida em que possuem instituições mais sólidas, mais transparentes, mais sustentáveis e orientadas ao planejamento de longo prazo. Em adição, a responsabilização jurídica é mais presente em países desenvolvidos, endereçando na medida do tempo e da necessidade as questões que exigem a força e a prevalência das leis. Ao nível do Estado, os países desenvolvidos enfrentam menos burocracia, menos hierarquização e, no âmbito corporativo público ou privado, maiores oportunidades de ascensão profissional baseada no mérito. O ambiente é mais propício ao empreendedorismo, à submissão a maiores riscos, tendo em vista aspectos como um sistema de seguro desemprego adequado à dinâmica de risco da 
atualidade. Além disso, a presença de melhores infraestruturas básicas, como transporte, redes de luz, água e esgoto, escolas e hospitais, garantem melhor autonomia e bem-estar aos indivíduos.

The key question behind the strategy for the public sector is to identify the role of the government- both what the government should do and how it should do it. And the question should not be whether a particular activity should be carried on in the public or private sector, but how the two can best complement each other, acting as partners in the development effort. Related issues include what tasks should be undertaken at what level of government, and how governments can most effectively interact with "civil society," creating the conditions that are most conducive to the transformation of the whole society. (STIGLITZ, 1998, p. 25-26)

No âmbito do sistema internacional, o mundo desenvolvido possui maior contato com a fronteira do conhecimento, da ciência, da tecnologia e da inovação, o que lhe garante, nos estágios atuais do desenvolvimento, um diferencial estratégico. Os países industrializados possuem maiores possibilidades de acesso com outras culturas, outras realidades econômicas e sociais e, em alguma medida, maior senso de integração, de pertencimento a um sistema único, global, da interação densa e constante entre os países, de cadeias globais e dos impactos da destruição ou da preservação humana.

\footnotetext{
An essential part of the new development strategies must be to take advantage of the new global environment while at the same time reducing the country's vulnerability to the inevitable shocks that are associated with global engagement. (STIGLITZ, 1998, p. 33, grifo nosso)
}

Ao final, a percepção de que realidades diferentes exigem soluções diferentes é fator primordial à minimização das desigualdades de oportunidades entre países desenvolvidos e em processo de desenvolvimento. As soluções propostas por agências internacionais, como a ONUDI, em relação ao fortalecimento do setor industrial não são condenáveis, mas ainda incompletas, pois negligenciam ou omitem 
as carências básicas estruturantes ainda existentes nos países em processo de desenvolvimento, tanto ao nível dos homens, dos Estados, como de sua percepção sobre o contexto internacional. 


\section{CONCLUSÕES}

As novas demandas de mercado e tendências industrias da atualidade exigem a formulação de novas estratégias de industrialização, que contemplem as realidades diferenciadas dos países em desenvolvimento. As crescentes preocupações sobre a importância estratégica do setor industrial para o desenvolvimento dos Estados serão amenizadas, na medida em que os países apliquem novas dinâmicas produtivas e industriais, que proporcionem maior agregação de valor, maior aproximação ao setor de serviços, maior inserção em cadeias globais e maior ênfase na pesquisa, no desenvolvimento e na inovação. Afinal, como Chang (2006) destaca, uma estratégia adequada ao desenvolvimento deve ser multidimensional.

Apesar das particularidades das economias de cada país desenvolvido, identificou-se uma relativa convergência na orientação de suas políticas industriais, que enfatizam, em grande medida, a geração de conhecimento e estímulo à inovação, o fomento às capacidades produtivas, a capacitação dos recursos humanos, a manutenção e modernização dos recursos energéticos, o aprimoramento de sistemas de financiamento, principalmente para pequenas e médias empresas, e a inserção em mercados globais.

Também foi observado que o mundo em desenvolvimento e as orientações propugnadas por organizações especializadas, como a ONUDI, parecem seguir diretrizes industriais similares, mas, por vezes, incompletas, pois negligenciam a realidade diferenciada a que ainda estão condicionados os países em desenvolvimento. O redimensionamento dos níveis de intervenção nos projetos industriais e a estruturação de um ecossistema básico ao desenvolvimento são passíveis de tornar-se a força motriz para a elaboração de políticas industriais, sem as quais os países em processo de desenvolvimento não lograrão minimizar desigualdades internas e em relação aos parceiros internacionais.

Políticas públicas adequadas à construção desse ecossistema básico têm papel estratégico ao desenvolvimento dos Estados, para que estimulem a criação de novas tecnologias, para que provoquem externalidades de conhecimento positivas e que ampliem a rede de empreendedores inovadores nos países. $O$ desenvolvimento por meio do estímulo do setor industrial se faz não só entre empresários, mas também entre os demais atores mobilizados nessa dinâmica, como setor público, academia e 
sociedade civil. Nesse sentido, políticas industriais bem estruturadas tendem a minimizar a divergência de renda per capita, ampliando a capacidade de absorção científica e tecnológica dos países em processo de desenvolvimento no contexto global que exige a integração entre as diferentes economias.

Um ecossistema propício ao desenvolvimento pode ser alcançado por meio da reformulação dos setores industriais de países em processo de desenvolvimento, no intuito de estimular novos negócios. Deve, assim, atuar no fortalecimento da segurança jurídica dos investimentos, na modernização da legislação trabalhista, na educação técnica e gerencial de qualidade, na ampliação de infraestruturas, na criação de sinergias entre os setores privado, público e acadêmico e, sobretudo, solvendo as deficiências existentes nos três níveis, Homem-Estado-Sociedade Internacional, enunciadas por Waltz. A estruturação do setor industrial de países em desenvolvimento em patamares sofisticados é um imperativo a ser realizado por governos e organizações de estímulo industrial, em nível nacional e internacional.

As políticas industriais tradicionais se tornaram ineficazes para dinamizar o setor industrial, minimizar as desigualdades sociais, a divergência de renda e aprimorar a inserção dos países em desenvolvimento no contexto global. Isso ocorre porque os instrumentos convencionais colidem com a estrutura de promoção econômica regida pela governança econômica internacional. É necessário, portanto, que os países em processo de desenvolvimento estruturem políticas ambiciosas à elevação da densidade industrial, à agregação de valor, à integração econômica, para que se tornem agentes de seu próprio desenvolvimento.

As novas dinâmicas da economia global requerem investimentos em capital humano, em ciência e tecnologia, em atividades geradoras de conhecimento e aprendizado. O setor industrial tem se mostrado locus principal dessas atividades. Para o incremento do setor industrial, é necessário, também, a exploração de recursos que reforcem esta estratégia, como a intensificação do comércio e a inserção em cadeias globais de valor de forma qualificada, a internacionalização de empresas, a realização de parcerias e a atração de centros de pesquisa e desenvolvimento aos países em processo de desenvolvimento e, sobretudo, o engajamento às tendências globais que orientarão a elaboração das políticas em prol do desenvolvimento.

A estratégia das nações em desenvolvimento deve ser, portanto, orientada pela necessidade de romper com a atual realidade a que estão condicionados e aumentar 
a densidade industrial, explorando as vantagens comparativas e incrementando as negociações com os países desenvolvidos para que venham a compartilhar com esses atores oportunidades igualitárias de comércio, investimentos e tecnologia. Mais do que se guiar por regras padronizadas, os países em processo de desenvolvimento precisam criar estratégias que institucionalizem a construção de um ecossistema próprio, ampliando o bem-estar social, o crescimento econômico e o desenvolvimento humano como um todo. 


\section{REFERÊNCIAS BIBLIOGRÁFICAS}

AMADEO, Edward. Política Industrial: historiografia e condicionantes de seu sucesso. Desenvolvimento em Debate: Painéis do desenvolvimento brasileiro I, Rio de Janeiro, v. 2, p.155-190, $2002 . \quad$ Disponível em: <http://www.bndes.gov.br/SiteBNDES/export/sites/default/bndes_pt/Galerias/Arquivo s/conhecimento/livro_debate/2-PolitIndustrial.pdf>. Acesso em: 10 nov. 2015.

ANDRADE, Jackeline Amantino. Redes de atores: uma nova forma de gestão das políticas públicas no Brasil? Gestão \& Regionalidade, n. 64, p. 52-66, 2006.

ARBACHE, Jorge. Como Dinamizar a Participação do Brasil nas Cadeias Globais de Valor. Brasília. 2014.

ARBACHE, Jorge. Convergência ou Divergência de Renda? Desafios do Desenvolvimento no Século XXI. Brasília. 2015.

CALLON, Michel. Society in the making: the study of technology as a tool for sociological analysis. In: BIJKER, Wiebe E., HUGHES, Thomas P., PINCH, Trevor J. The social construction of technological systems: new directions in the sociology and history of technology. Cambridge, Massachusetts: The MIT Press, 1987. cap. 1.

CHANG, Ha-Joon. Kicking away the Ladder: The Myth of Free Trade and the Secret History of Capitalism. New York: Bloomsbury. 2008.

CHANG, Ha-Joon. The East Asian development experience, the miracle, the crisis and the future. New York: Zed Books. 2006.

CHANG, Ha-Joon; ANDREONI, A; KUAN, M. L. International Industrial Policy Experiences and the Lessons for the UK. Londres. 2013. Disponível em: <https://www.gov.uk/government/uploads/system/uploads/attachment_data/file/2771 62/ep4-international-industrial-policy-experiences.pdf>. Acesso em: 10 nov. 2015. 
CONFEDERAÇÃO NACIONAL DA INDÚSTRIA. Serviços e Competitividade Industrial no Brasil. Brasília, 2014.

DEDIU, H. When Will Smartphones Reach Saturation in the US? 2012. Disponível em: <http://www.asymco.com/2012/04/11/when-will-smartphones-reach-saturation-in-theus/>. Acesso em: 11 nov. 2015.

DG Enterprise and Industry. EU Manufacturing Industry: What are the Challenges and Opportunities for the Coming Years? In: The 2nd High Level Conference on Industrial Competitiveness, Brussels, Belgium: European Commission, 2010.

FUJIMOTO, Takahiro. The Evolution of a Manufacturing System at Toyota. New York: Oxford University Press, 1999.

FUTURE MANUFACTURING COUNCIL. Trends in Manufacturing to 2020: A Foresighting Discussion paper. Canberra, Australia: Future Manufacturing: Department of Innovation, Industry, Science and Research, 2011.

GERMANY TRADE \& INVESTMENT. Germany's Wind Energy Industry. Berlin, 2013. Disponível em: <http://www.gtai.de/GTAl/Content/EN/Invest/_SharedDocs/Downloads/GTAI/Industry -overviews/industry-overview-the-wind-energy-industry-en.pdf>. Acesso em: 11 nov. 2015.

HAUSMANN, Ricardo; RODRIK, Dani; VELASCO, Andrés. Getting the Diagnosis Right. Finance and Development 43, 2006. Disponível em: <http://www.imf.org/external/pubs/ft/fandd/2006/03/hausmann.htm>. Acesso em: 11 nov. 2015.

HIROTA, Hercília. Desenvolvimento de Competências para a Introdução de Inovações Gerenciais na Construção Através da Aprendizagem na Ação. 2001. 205 f. Tese (Doutorado em Engenharia Civil) - Faculdade de Engenharia, Universidade Federal do Rio Grande do Sul, Porto Alegre. 
HM GOVERNMENT. Building Britain's Future: New Industry, New Jobs. London, 2009.

INFORMATION TECHNOLOGY \& INNOVATION FOUNDATION (ITIF). Case for a National Manufacturing Strategy. Washington D.C., 2011.

KETELS, Christian H. Industrial Policy in the United States. Journal of Industry, n. 3-4, p.143-323, 2007.

KUPFER, David; HASENCLEVER, Lia. Economia Industrial: Fundamentos Teóricos e Práticas no Brasil. Rio de Janeiro: Elsevier, 2013.

LATOUR, Bruno. Reagregando o social: uma introdução à teoria do Ator-Rede. Salvador: Edufba, 2012.

LAW, John. Technology and heterogeneous engineering: the case of Portuguese expansion. In: BIJKER, W., HUGHES, T. P., PINCH, T. J. The social construction of technological systems: new directions in the sociology and history of technology. Cambridge, Massachusetts: The MIT Press, 1987.

LIN, Justin Yifu. Economic Development and Transition: Thought, Strategy and Viability. Cambridge: Cambridge University Press, 2009.

MADDISON, Angus. The World Economy. Paris: OECD, 2006.

MARSH, Peter. The New Industrial Revolution: Consumers, Globalization and the End of Mass Production. New Haven, CY: Yale University Press, 2012.

MAZZUCATO, Mariana. O Estado empreendedor: desmascarando o mito do setor público vs. setor privado. São Paulo: Portfolio-Penguin, 2014.

MIROUDOT, Sébastien; LANZ, Rainer; RAGOUSSIS, Alexandros. Trade in Intermediate Goods and Services. OECD Trade Policy Working Papers, 2009. 
MURPHY, Kevin M.; SHLEIFER, Andrei; VISHNY, Robert W. Industrialization and the Big Push. Journal of Political Economy 97(5): 1003-26, 1989.

PIORE, Michael; SABEL, Charles. The Second Industrial Divide. New York: Basic Books, 1984.

PORTER, Michael E. The Competitive Advantage of Nations. London: Free Press, 1990.

ROBINSON, James A. Industrial Policy and Development: A Political Economy Perspective. Harvard University, 2009. Disponível em: < http://scholar.harvard.edu/jrobinson/publications/industrial-policy-and-developmentpolitical-economy-perspective>. Acesso em: 11 nov. 2015.

ROSENSTEIN-RODAN, P. Notes on the Theory of the "Big Push". In: ELLIS, H. S.; WALLICH, H. C., Economic Development for Latin America. New York: St Martin's Press, 1961.

SAURÉ, Philip. Revisiting the Infant Industry Argument. Journal of Development Economics 84 (1): 104-17, 2007.

STIGLITZ, Joseph E.; GREENWALD, Bruce C. Creating a Learning Society. New York: Columbia University Press, 2014.

STIGLITZ, Joseph E. Towards a New Paradigm for Development: Strategies, Policies, and Processes. Prebisch Lecture at UNCTAD. Geneva, 1998.

SCIENCE AND TECHNOLOGY POLICY INSTITUTE (STPI). White Paper on Advanced Manufacturing Questions. The Advanced Manufacturing Workshop of the President's Council of Advisors on Science and Technology's Study on Creating New Industries through Science, Technology and Innovation, Science and Technology Policy Institute, 2010. 
UNCTAD. The least Developed Countries Report. Geneva, 2014. Disponível em: <http://unctad.org/en/PublicationsLibrary/ldc2014_en.pdf>. Acesso em 11 nov. 2015.

UNITED NATIONS. World Populations Prospects: The 2008 Revision Population Database. New York and Geneva: United Nations Department of Economic and Social Affairs, 2011.

UNIDO. Emerging trends in global manufacturing industries. Viena, 2013a. Disponível em:<http://www.unido.org/fileadmin/user_media/Services/PSD/Emerging_Trends_U NIDO_2013.PDF>. Acesso em 11 nov. 2015.

UNIDO. Industrial Development Board (IDB) 41/24 Forty-first session. Viena, 2013b. Disponível em: <http://www.unido.org/fileadmin/user_media/PMO/IDB/IDB41/idb41_24e.pdf>. Acesso em 11 nov. 2015.

UNIDO. Industrial Development Report 2013 - Sustaining Employment Growth: The Role of Manufacturing and Structural Change. Viena, 2013c. Disponível em: $<$ https://www.unido.org/fileadmin/user_media/Research_and_Statistics/UNIDO_IDR_ 2013_main_report.pdf>. Acesso em 11 nov. 2015.

UNIDO. Independent Thematic Evaluation: Thematic Evaluation of UNIDO projects related to "Industrial Upgrading". Viena, 2013d. Disponível em: <http://www.unido.org/fileadmin/user_media_upgrade/Resources/Evaluation/THEMUpgrading-2011_ebook.pdf>. Acesso em 11 nov. 2015.

UNIDO. Programme and Budgets 2014-2015. Viena, 2013e. Disponível em: <http://www.unido.org/fileadmin/user_media/PMO/PBC/PBC29/pbc29_5e_new.pdf>. Acesso em 11 nov. 2015.

UNIDO. Introduction to UNIDO: Inclusive and Sustainable Industrial Development. Viena, $2014 . \quad$ Disponível em: 
<https://www.unido.org/fileadmin/user_media_upgrade/Who_we_are/Structure/Direct or-General/DG_UNIDO_FINAL_WEBs.pdf>. Acesso em 11 nov. 2015.

UNIDO. Industrial Development Board (IDB) 43/09 Forty-third session. Viena, 2015. Disponível em: <http://www.unido.org/fileadmin/user_media/PMO/PBC/PBC31/pbc31_9en.pdf >. Acesso em 11 nov. 2015.

VINER, Jacob. Studies in the Theory of International Trade. New York: Harper and Brothers Publishers, 1937.

WARWICK, Ken. Beyond Industrial Policy: Emerging Issues and New Trends. OECD Science, Technology and Industry Policy Papers, No. 2, OECD Publishing, 2013. Disponível em: <http://dx.doi.org/10.1787/5k4869clw0xp-en>. Acesso em 11 nov. 2015.

WARWICK, Ken; NOLAN, Alistair. Evaluation of Industrial Policy: Methodological Issues and Policy Lessons. OECD Science, Technology and Industry Policy Papers, no 16, OECD Publishing, 2014. Disponível em: <http://www.oecd-ilibrary.org/scienceand-technology/evaluation-of-industrial-policy_5jz181jh0j5k-en>. Acesso em 11 nov. 2015.

WESSNER, Charles W.; WOLFF, Alan W. Rising to the Challenge: US Innovation Policy for Global Economy. Washington. DC. National Academy of Science Press, 2012.

WORLD ECONOMIC FORUM. New Models for Addressing Supply Chain and Transport Risk. Geneva, 2012.

WOLFFENBUTTEL, Andréa. Investimento estrangeiro direto: desafios do desenvolvimento. 2006, ano 3, edição 22. Disponível em: $<$ http://desafios.ipea.gov.br/index.php?option=com_content\&view=article\&id=2103:ca tid=28\&ltemid=23>. Acesso em 11 nov. 2015. 